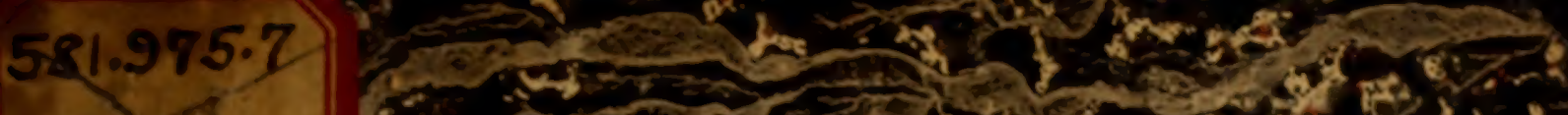

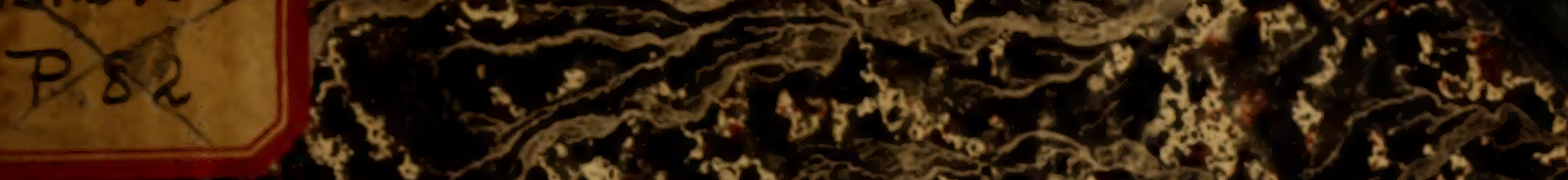

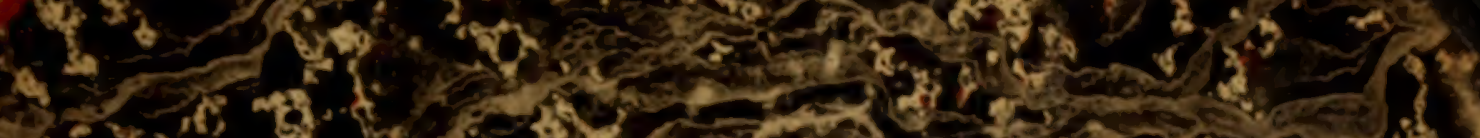

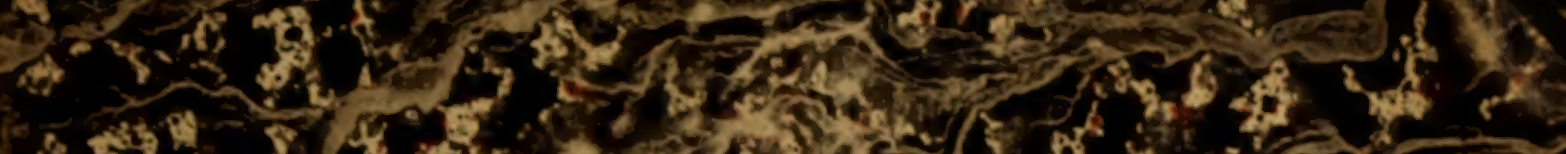

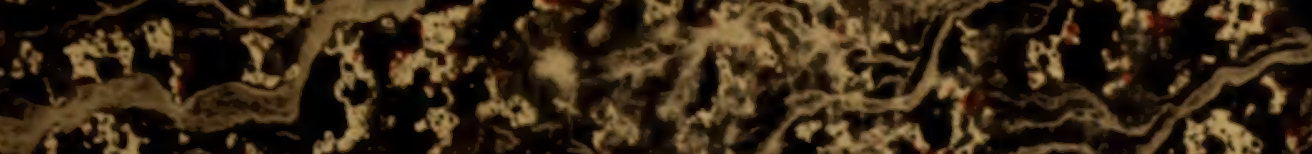

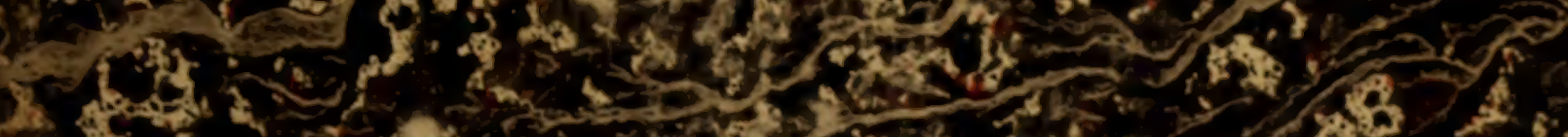

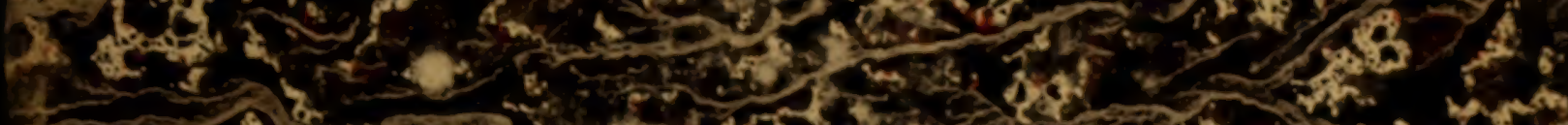

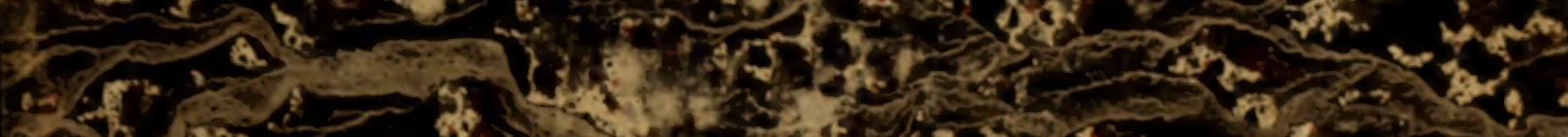

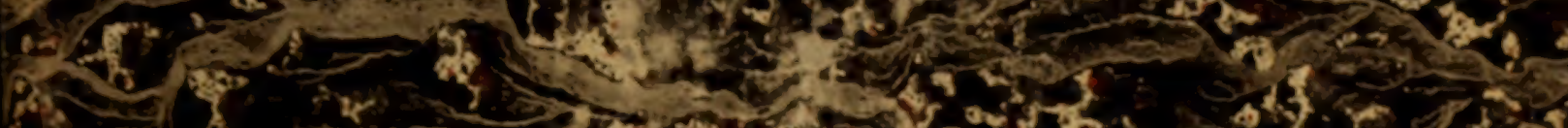

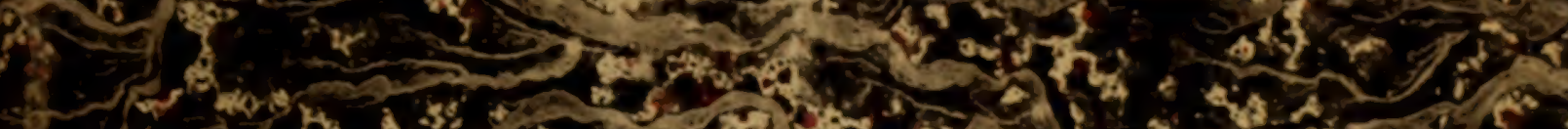

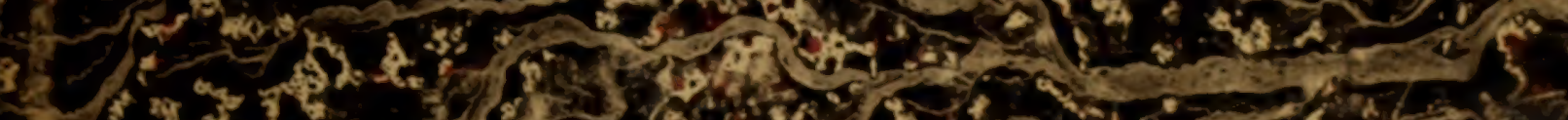

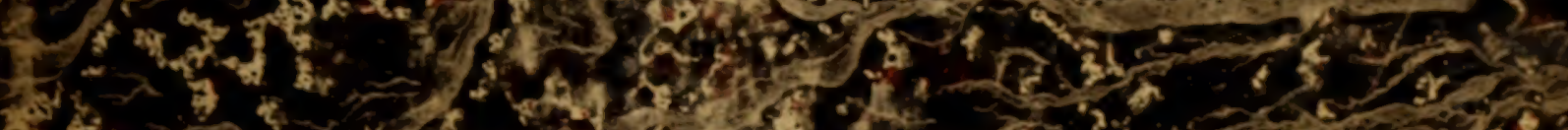

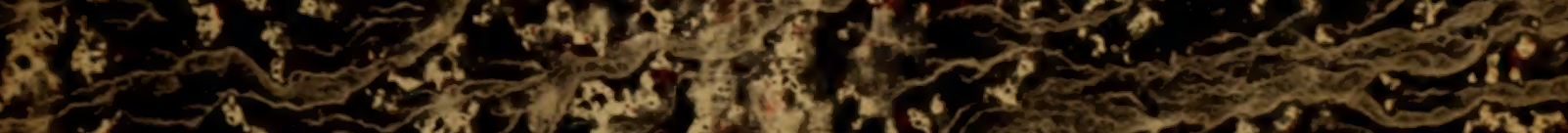

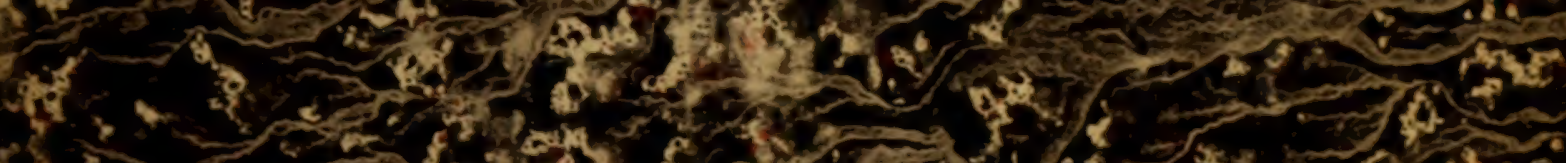

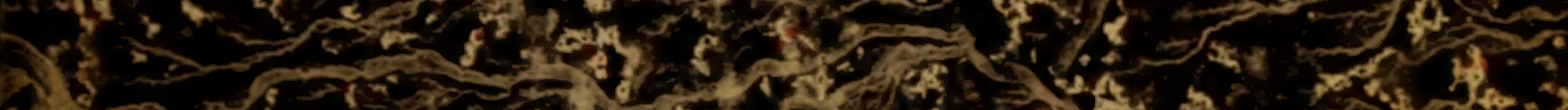

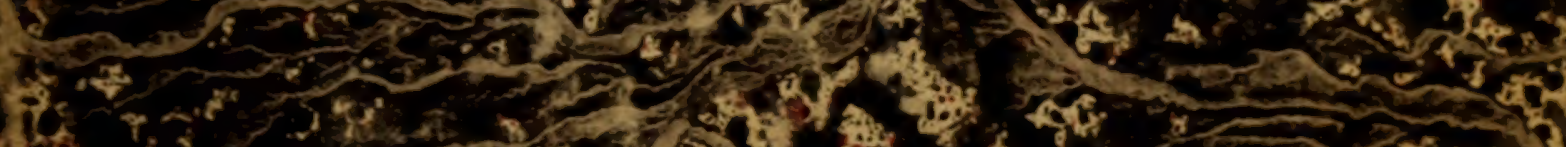

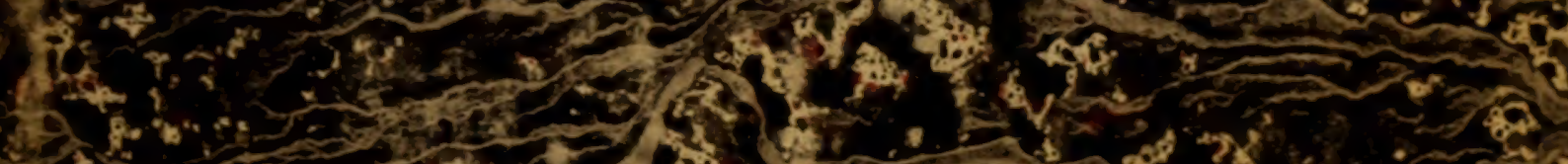

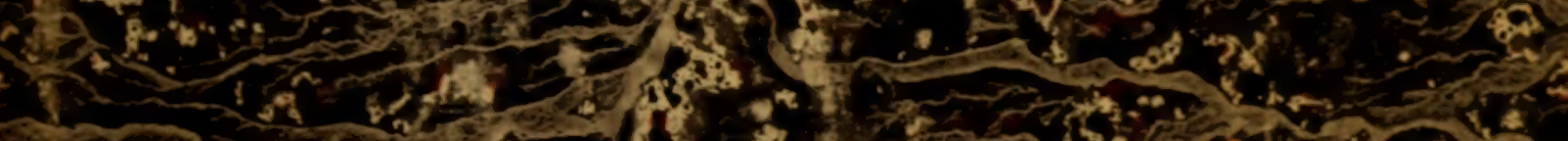

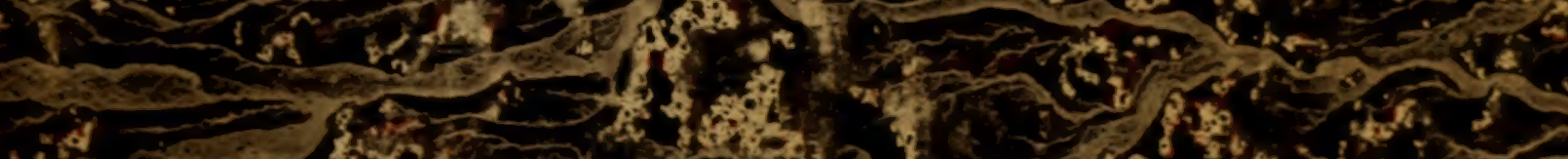

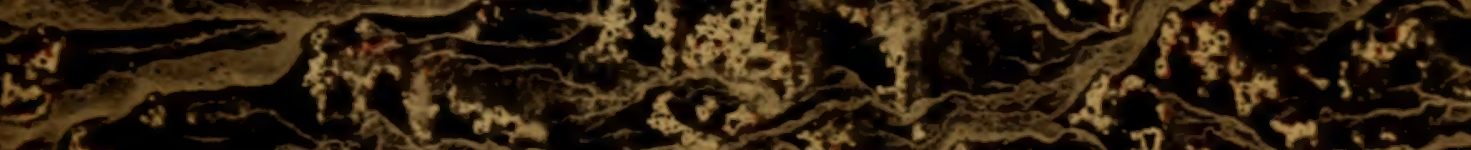

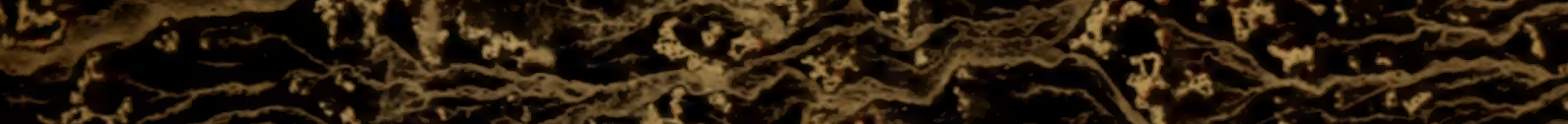

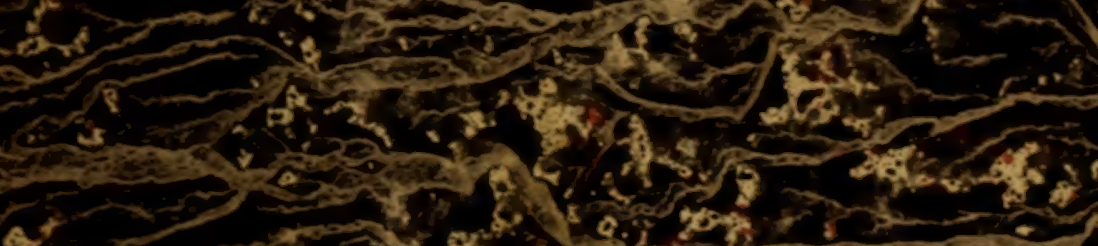

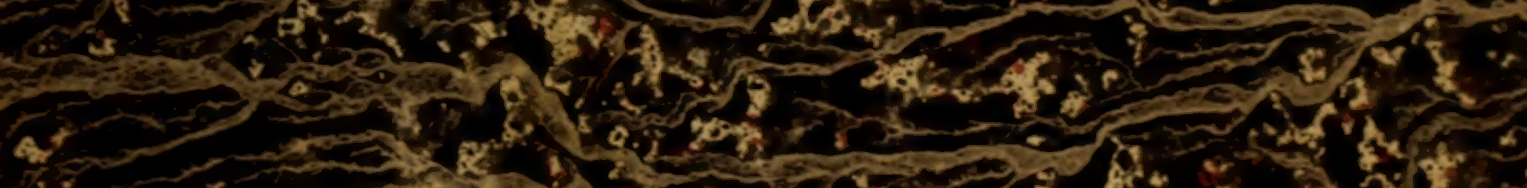

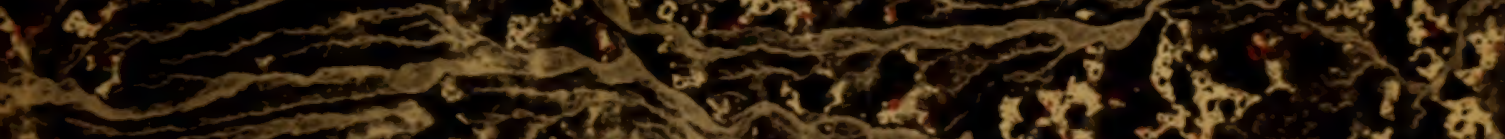
5 - 7 है

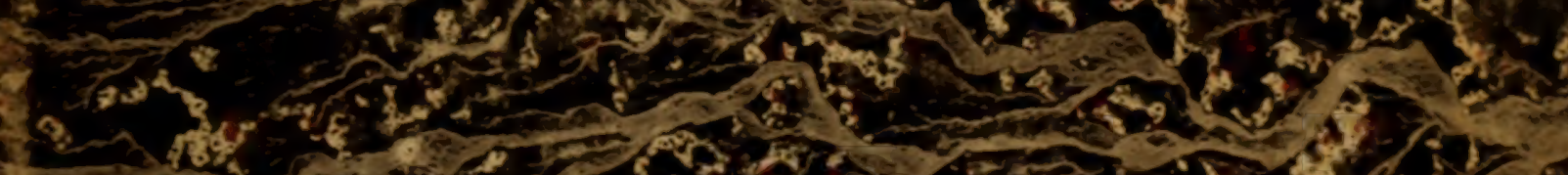

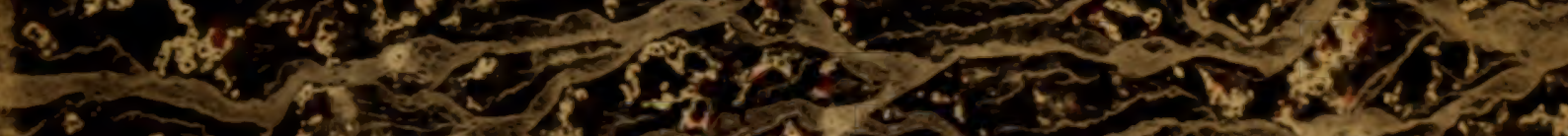

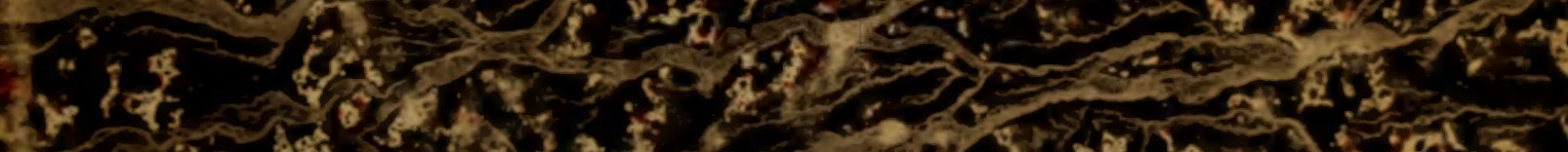

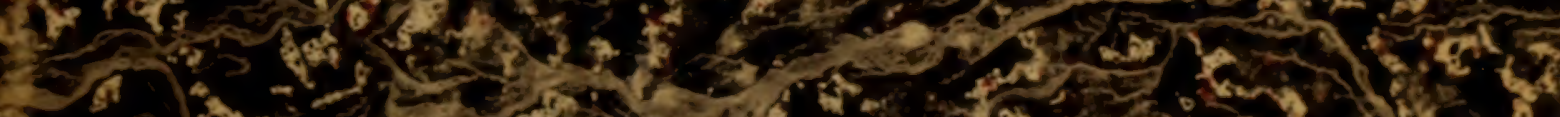

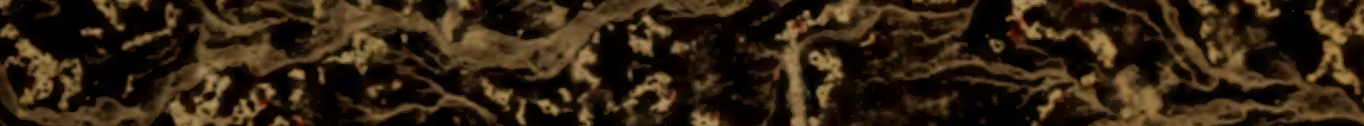

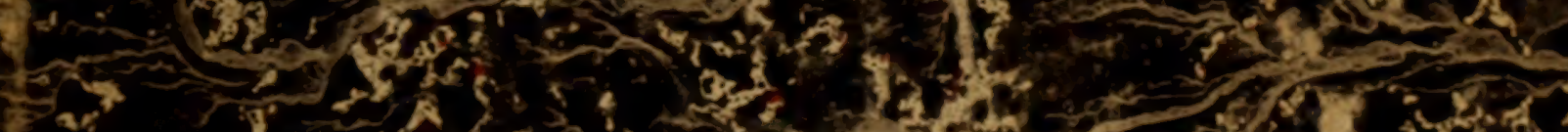

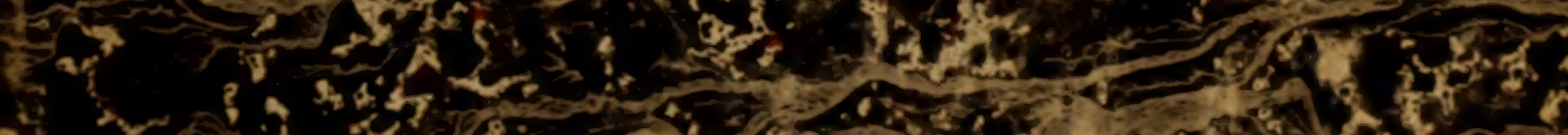

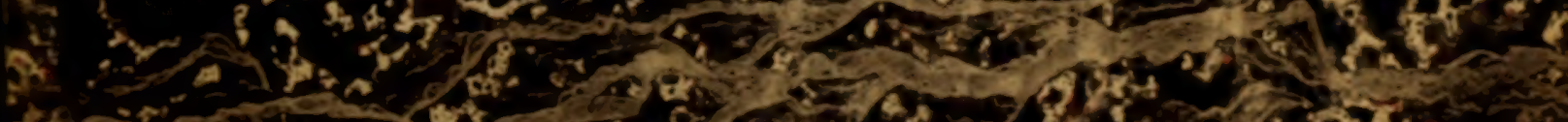

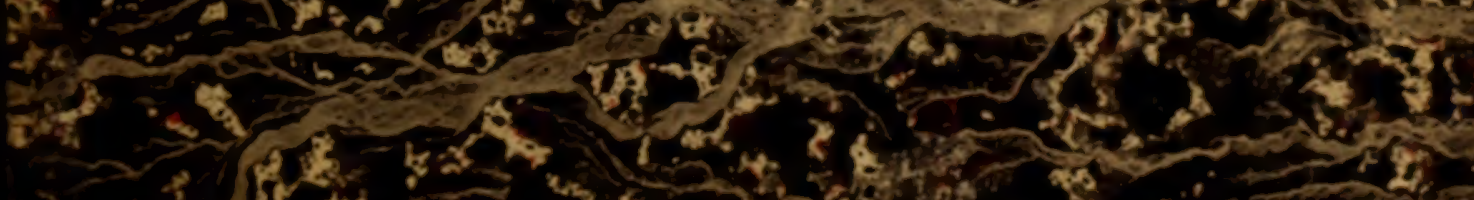

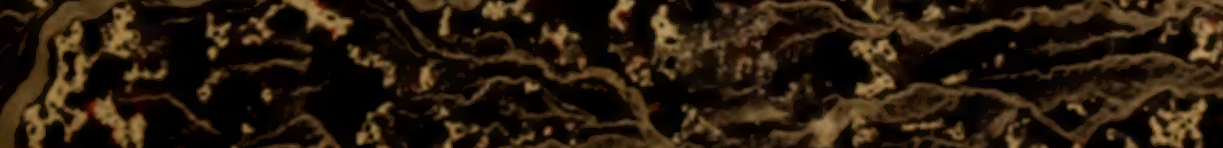

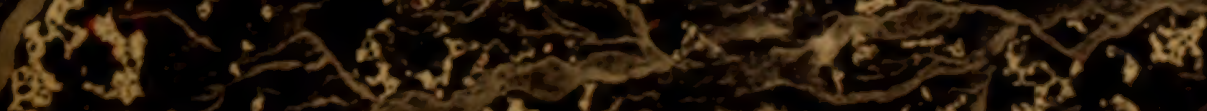
6. 3 20 


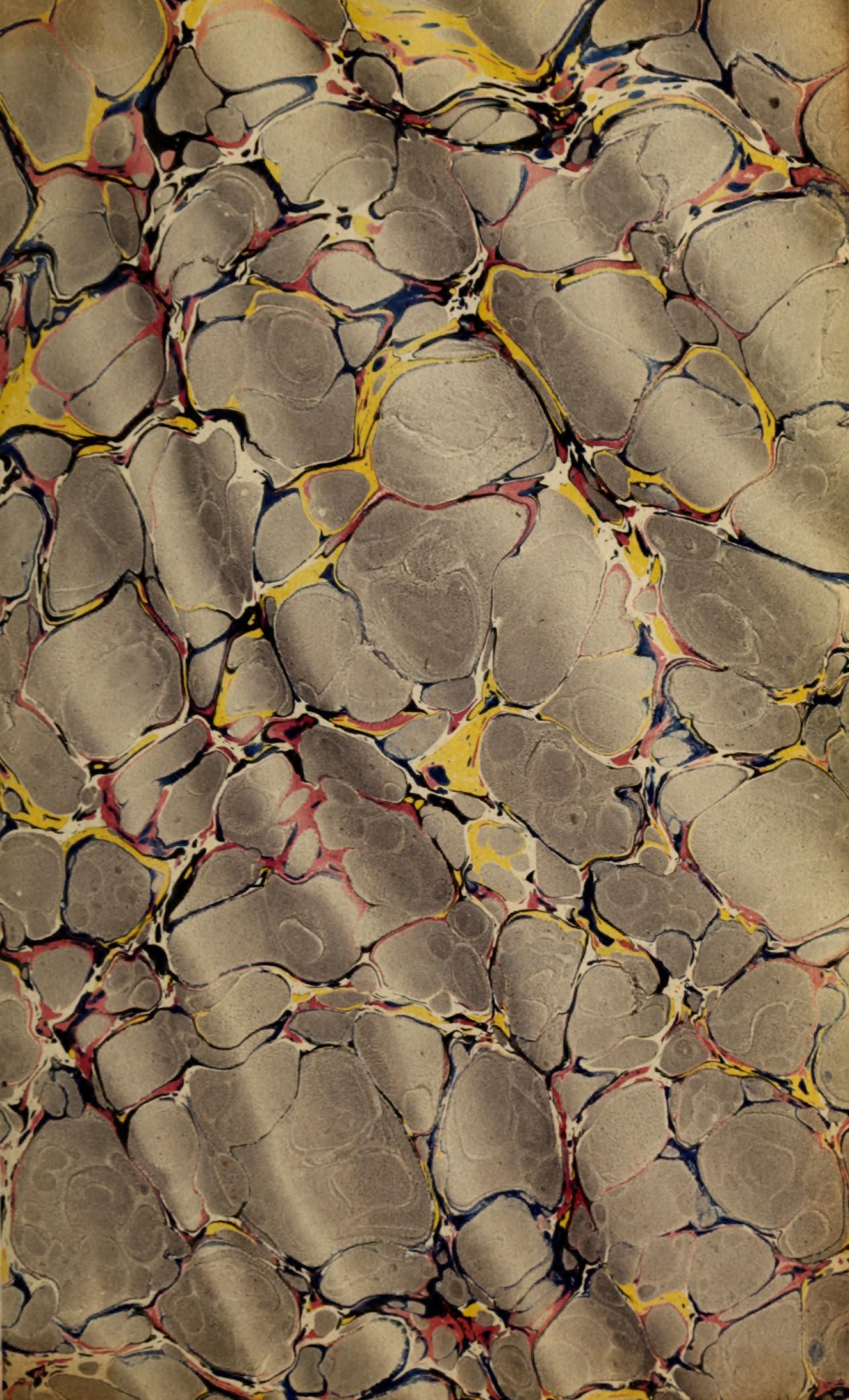


2427 
a golutions

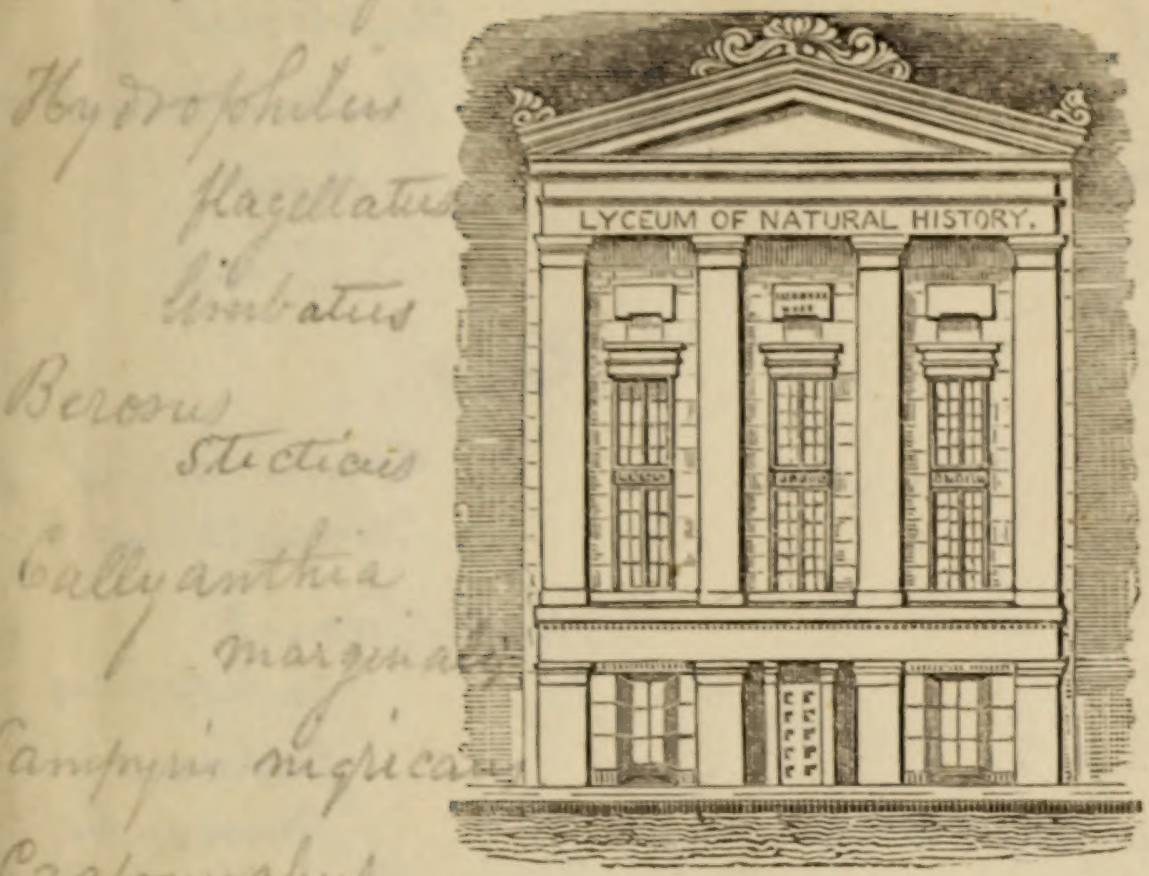

Eugout

SIR,

I have the pleasure to announce to you, that at a Meeling of the "LYCEUM OF NATURALMISTORY," held on the $\quad \xi \frac{z d}{"}$ instant, you were elected a retide h

Member thereof.

The Meetings of the Lyceum are held on Monday Evening of each week, at their New Building, No. \$s8 Broadway.

New-Yorr, May $8^{\frac{1}{1 \prime}} 18$

Secretary. 


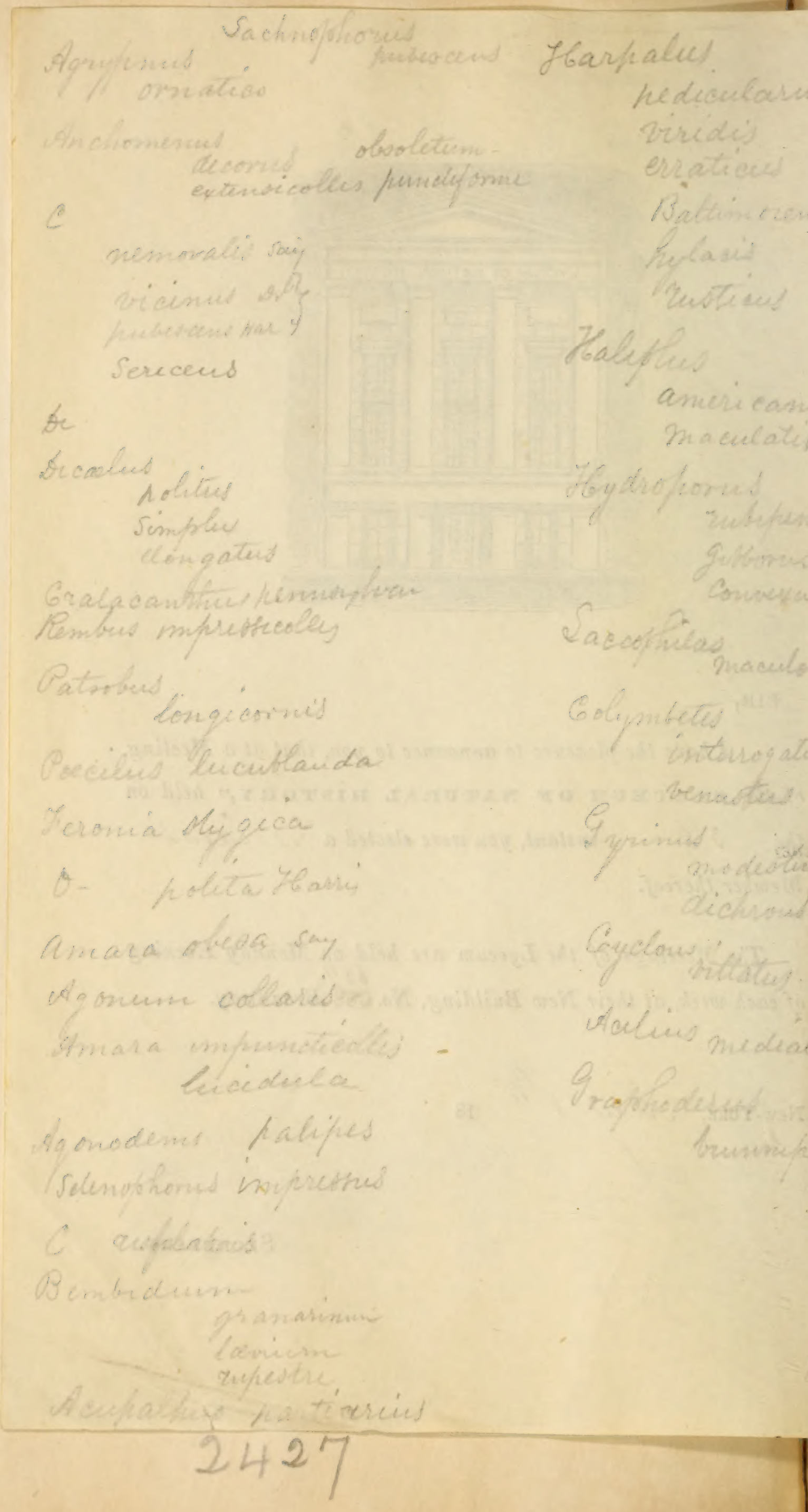






\section{A \\ MEDIO0-BOTANICAL OATALOGUE}

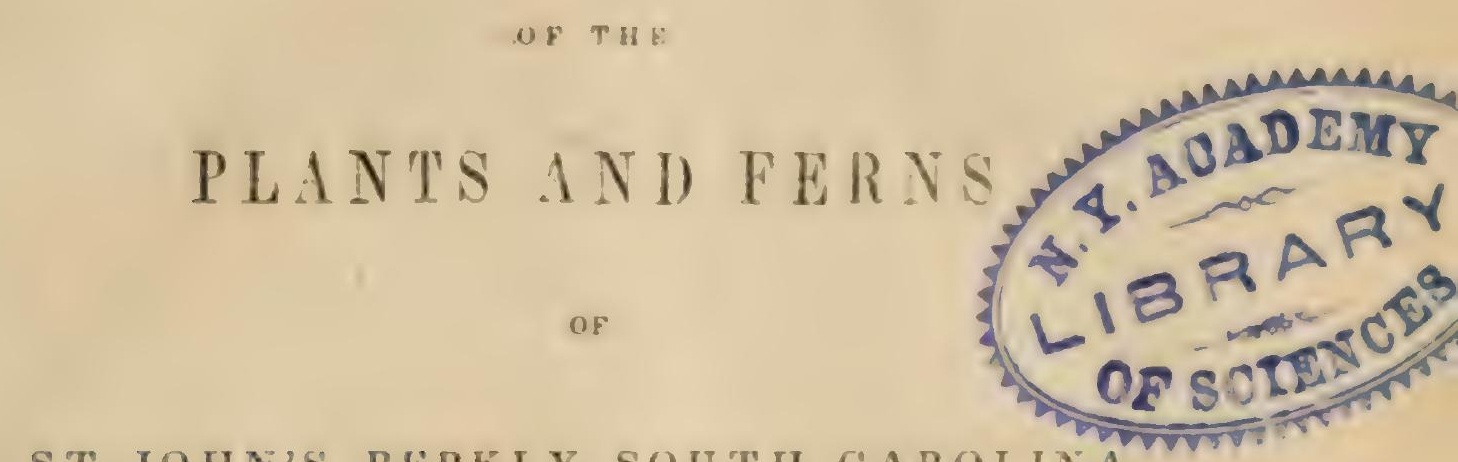

ST. JOHN'S, BERKLY, SOUTH-C AROLINA.

LIBRARY
NEW YORK
BOTANICAL
GARDEN

I N I UGURALTHESIS

SLBMITTED TO THE:

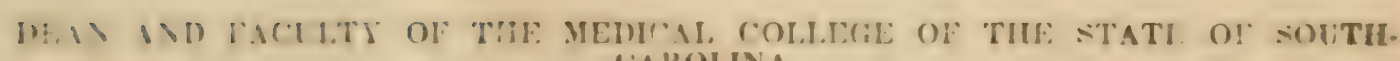
CAROLINA

FOR THE DEGREE OF M. D.,

BY

FRANCIS PEYRE PORCHER.

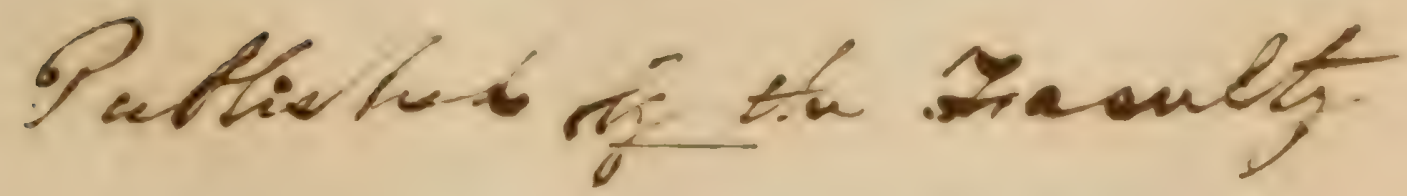

\section{CHARLESTON :}

PRINTED BY BUROES A ND JAMEE.

1847. 


$$
\begin{aligned}
& P Q<99 \\
& P 65
\end{aligned}
$$




\title{
MEDICO-BOTANICAL O.ITALOGUE
}

\author{
CF TIF.
}

\author{
PI.ATS AND FERNS OF ST. JOHN'S, BERKLY, SOUTH- \\ CAROLINA.*
}

"The remark of Dr. Macbrite to Professor Ives, to the effect, that we should only obtain a knowledge of the natural productions of the country, when literary and philosophical societies shall record the observations, and secure the local Flora's, prepared by accurate examiners."-Preface to Lidton's Bulan!, Th Ed.

$W_{E}$ shall not here speak of the advantages attending the study either of General or Medical Botany, but only ohserve, that to the inquirer in this department, complete catalogues of the plants of circumscribed localities are not merely useful by determining the habitat and range of species, but acquire additional value from the fact that they diminish labor. Performing for each locality what Elliott's sketch did for the State at large, they enable the student to confine himself with the same advantage and at the expense of less time and trouble to a limited number. Without being compelled to search thronghout the numerous species of a compendious North American Botany, he has only to notice those of whose existence he is already advised. And thus they contribute more rapidly to develope the natural resources around him. We have endeavored to ally this one more closely to medicine, and render it not without interest to physicians generally,

- This esary was presented to the Faculty of the Medical Collegeof the state of South-Carolina, and olutained the prize, awarded by a commuttee of medical gentlemen, appointed for the purpose of selerting, from among the theses offered for the degree of M.D., that most worthy of publication. 
by inserting numerous references to works which contain desirable information, concerning those possessing medicinal or useful qualities. The investigation necessary for ascertaining and collecting these, has unfolded a vast fund of facts relative to the virtues of a large proportion, as it will be observed, of the plants both obscure and well known among us. It has also convinced us of the truth of the assertion, that we have every means for the preservation and restoration of health, in the indigenous varieties so remarkably abundant in the lower portions of SouthCarolina.

It will be seen that we have consulted both the older and more recent works on the Materia Medica-from Cullen and Burguis, down to Pereira and Bell. Matson's Vegetable Practice to us was worthy of notice-containing as it does exclusive reference to the herbs upon which, the so-called, steam practitioners rely. We must not omit calling attention to that very complete and extensive work in 6 vols by Merat and de Lens, the Dict. Univ. de Matière Médicale. In it can be found much concerning our Medical Flora-much that is not generally known or not alluded to in the Dispensatories-and which might be of essential service to those not merely desirous of ascertaining what has already been discovered, but also more thoroughly of investigating the hidden qualities of others. Frequent reference is made to Journals which contain nonographs, inangural theses, and special dissertations on particular plants. Pesides a notice of those used in domestic practice on the plantations, we have introduced in a condensed form the diseases to which they have been applied; and that others not recognizing them under their botanical significations alone, may add to this, we will also, where we can obtain them, insert the common names to the medicinalspecies; these vary in different localities, and of course cannot be relied on. By presenting at one view the immediate sources from whence information is easily procured, each one, having his attention attracted to them, mav with greater facility proceed directly to the task of application, examination, or experiment; and thus we endeavor to embrace the true principles of advance, those. which enable every individual, to grasp at one glance all that has already been labored through and accomplished by his predecessors, and assuming their limits as the sturting point for fresh exertions, make more rapid strides toward new acquisitions. That the materials - the plants themselves, may be easily recognized and obtained, we have been at the pains to mark over against each, the month in which they were collected, and at any time may be found blooming - for the practical botanist, special reference is made to the precise spot where the more rare and remarkable can be seen-and at the instance of the State Geolo- 
gist, lidicating in every case," what kind of lands they prefer, whether oak, hickory, or swamp, whether immersed in ponds flourishing in inundated soils, or liring in dry pine barrens.

We must express our very great obfigation to $\mathrm{II}$. W. Ravenel, Esq., ol North Ilamptom, st. Johns lierkley, for the use of his catalogue, and for the determination and confirmation of unmerous spectes, but more particularly fur the graminese contained herein. Ile hats also assisted us in the valuable task of adapting mauy of Elliolt's species to the uomenclature of Laton's Maumal and of the still more recent work of 'Torry and Gray. The former is ailuded to because it has heen in such general use, the later is mow universally recognized as the standard by which genera are determined and symonymes compared. When that laborious work shall be completed, a science continually undergo ne alleration will demand the complete revision of Elliott's sketch.

We also ackinowledge the receipt of a list of plants, collected in the lower portion of the Parish by the Rev'd C. Wallace, from this we have derived two or three species which had escaped our notice. 'T'o Prof. L. R. Gibbes of the Charleston College, we are indehted for examining with us, and determining several unascertained species. Prof. C. U. Shephard has enahled us to compare some of our plants with those growing in a more northern latirude. Between 5ll and 100 doubtul specimens collected by Mr. Ravenel and myself, either not accurately described, or not contained in Eillint, have been transferred to that veteran botanist, Pro: Cray of Cambridge, and we have been gratified at recciring them in time, to enable us to embody and present them to the Ficulty of the South-Carolina Medical College.

In order that greater accuracy might be ensured, Dr. John Bachman very kindly allowed us to compare our specimens with bis nwu, and with those in the Herbarium of Mr. Elliont, at présent in his possession.

Thone alluded to by Elliotl or MacBride, as growing in the vicinly of the Santee Canal, which we have not seen, are distinguilhed by an asterisk ("); and in the body of the catalogue, we have designated those afterwards referred to as medicinal, by a cross (t), filaced on lines rumuing parallel with, and to the left of tile columns

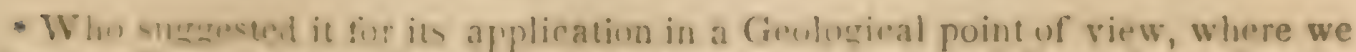

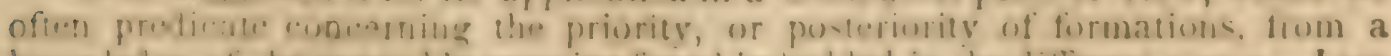

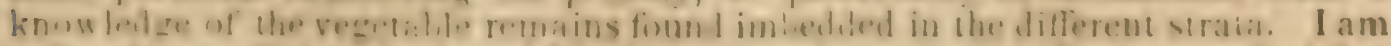

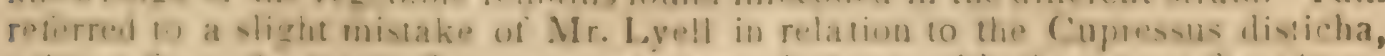

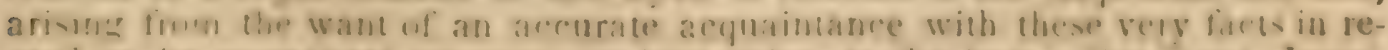

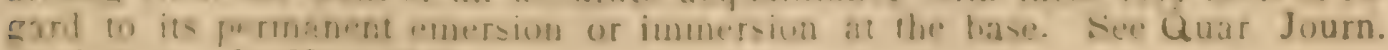
Geol. Socy., for Nov. 1816. 
A Medico-Botanical Catalogue of Plants, \&.c.

\author{
Indigenous Medicinal Plants of St. John's, Berkley. \\ REFERENCES AND USES.*
}

WORKS CONSULTED.

U. States Dispensatory, Wood \& Bache, 1845,

Thacher's U. S. Dispensatory,

Coxe's American Dispensatory,

Pereira's Materia Medica and Therapeu-? tics, 2 vols.

Edwards \& Vavasseur, Matiere Medicale, ? Paris, 1836 ,

Eberle's Mat. Med. and Therapeutics, Philad., 1834, 2 vols.

Practical Dictionary of Materia Medica, by Jno. Bell,

Bergii, Mat. Med. e regno vegetabili, \&c., Stockholmeæ, 1782 ,

Lewis, Mat. Med., London, 179I, 2 vols.

Trousseau et Pidoux, Traité de Thérapeu- ? tique, et de Mat. Médicale, Paris, 1837,

Royle's Mat. Méd., Philad., 1847,

Mêrat et De Lens Dictionaire de Matiere ? Médicale,

Cullen's Materia Medica,

Ballard \& Garrod's Materia Medica, 1846,

Barton's Medical Botany,

Barton's Collection towards the formation ? of a Materia Medica,

Chapman's Therap. and Mat. Med.

Woodville's Medical Botany,

Bigelow's Medical Botany, Boston, 1820,

Ellintt's Sketch of Botany of S. Carolina ? and Georgia, Cha'ston, 1821, Medical Notes,

Drayton's View of S. Carolina, Cha'ston. 1802 ,

Shecut's Flora Carolinæensis, or a History, medical and economical, of the Vegetable Kingdom, Cha'ston, 1806,

Matson's Vegetable Practice,

Frost's Elements of Mat. Medica,

English Physician, by Nich. Culpepper, Gent. "Student in Physic and Astrology," (no date, "An Astrologo-Physical Discourse on Vulgar Herbs," \&c.

Watson's Practice of "Physic, 2d Am. ed., ? 1845 ,

Lindley's Natural System of Botany, with the uses of important species in medicine, the arts, and domestic economy, London 1836,

Pharm. Journals, Reviews, Monographs, \&c.
ABBREVIATIONS USED

U. S. Disp.

Thacher's U. S. Disp.

Coxe Am. Disp.

Pe. Mat. Med.

Ed. \& Vav. Mat. Med.

Eb. Mat.-Med.

Bell's Pract. Dict.

Bergii Mat. Med.

Le. Mat. Med.

Trous, et Pid. Mat. Méd.

Royle Mat. Med.

Mêr. et de L. Dict. de Mat. Méd.

Cull. Mat. Med.

Ball. \& Gar. Mat. Med.

Bart. Med. Bot.

Bart. Coll. to form. of Mat. Med.

Chap. Mat. Med. and Th.

Woodv. Med. Bot.

Big. Med. Bot.

Ell. Bot. Med. Notes.

Dray. View.

Shec. Fl. Carol.

Mat. Veg. Pract.

Fr. Elems.

Culpepper Eng. Phys.

Watson's Pract. Physic.

Lind. Nat. Syst. of Bot.

* [n the original manuscript the catalogue followed the prefatory remarks; bur. as a division was necessary, we have taken the liberty to disturb the natural sequences, by reversing it, that we may add the result of Dr. Gray's examination? of duplicates not yet returned.] 
Achillea Millefolimm, (Milioil.)-I. S. Disp., p. 12.02 Appendix: Ed. \& Vav. Mat. Med., 26t: Le. Mat. Med., r. 11., 108; Hoffman "De praestantia remed. domest.," 18: Bergii Mat. Med., 738: Mat. Veg. Pract., 299: Mer. \& Del. Dict. de Mat. Med., t. I., 2.2 : Shec. Fl. Carol., 91: Libud. Yat. Syst., 253. It increases the intoxicating effects of drink-, and is used as it remedy for the insoluntary discharge of urine in children. . A ronic and antispasmodic in passive hemorrhage and lencorrhea.

Acrurus Calumus, (Calemus.)-Ve. Mat. Med. and Therap., I1., iti: Rovle's Mat. Med.. 602; Le. Mat. Med.. I., 251 : Hoffman Ohiservations Phys. Chim., t. I., Ots. I. : Eil. Bot. Note. I., 403; C. S. 1)isp., 145: Fd. \& Var. Mat. Med., 281; Ball. \& Gar. Mat. Med., 431: Bergii Materia Medici, 2st; Mer. E De I.., t. 1.. 63: Woodv. Med. Botany, Aun. de Chim., LXXXI., 332; Coxe Am. Disp. 15: Shec. Fl. Carol.. 9t. In aromatic stimulant and stomachic. Fd. \& V av. state that it has been administered successfully in intermittent fever. "On l' a beaucoup ranté pour combatre les symptomes cérêbraux qui accompagnent la séconde période des fièrres dites ataxiques." Op. cit., 25:2. It is used as a remedy for flatulency.

Achyranthes repeus, (Forty kuot.)-Fr. Elems., 2si. A valuable diuretic in ischury and dysury.

Aesculus pavin. (Buck eye, Horse chesnut.) -. Shec. Fl. Carol., 105. Relieves tooth-ache; has the property of intoxicating fish when thrown in pools of standiner water. (See Ell. Bot.) Starch is made from the fruit.

Agrave Virginica. - Ell. Bot.. I., 402. A domestic remedy for flatulent colic: used in St. John's for the bite of the rattle-snake; called, by negroes, rattle-snakes master It grows in Wassamasaw, and is not very common.

Aerimonia cupuluria. (Agrimony.) - Ed. \& Yar. Mat. Méd., 133: Pitr's Med. 1)ict., art. Agr. cupatoria: U. S. Disp., 1224; App. Le. Mat. Med., I., 42; Cullen's Mat. Med.. II., 31 ; Bergii Mat. Med., I.. 40.1 : Mer. \& De I. Dict. de M!at. Med., t. I., 114; Shec. Fl. Carol., III.: Lind. Nat. Syst. of Bot., 114. With bismuth. it imparts a grolden dye to woo!. An astringent in passivo hemorrhage, gonorrhoea and lencorrhnea. highly recommended as a denbstrment in jumndice and visceral obstructions. (See Op. cit.) The Indians use it intermittent fever.

Aletris aurea, (Yellow Star Grass.)-Eill. Bot., I., 39; Fr. Elens., 253; U.S. Disp., 67. Purgative and nauseating iu large doses.

A. furinosa, (Unicorn Ront.)-Pe. Mat. Med. and Therap., II. 121 ; Fr. Elems., 253; Mer. \& IrL. Dict. de Mar. Med., t. I., 161 ; Lind. Nat. Syst. of Bot.. 353; Biq. Am. Med. Bot., III., 92; Clayton's Phil. Trans., abr. VIII., 333 ; Culler Am. Acad., I., 435. Both of these plants have been used with success in in- 
termittent fevers, attended with dropsical swellings-loc. cit. Employed as a tonic in domestic practice on the plantations.

Alnus serulata, (Alder.)-Shec. Fl. Carol., 273; see Betula alnus, (op. cit.) Used as an alterative in scrofula.

Ambrosia artemisifolia.-Mer. et DeL. Dict. de Mat. Med., t. I., 227.

Amaryllis atamasco, (Atamasco lily.)_Ell, Bot., I., 384 ; supposed to produce the disease in cattle called 'staggers.'

Anagallis arvensis, (Red chickweed.)-U. S. Disp., 1227, app.; Le. Mat. Med., I., 80 ; Mer. \& DeL. Dict. de Mat. Med., t. I., 276; Woodv. Med. Bot. Orfila Toxicologie, II., 275; Mem. Acad. Royal de Med., 18, Mars. An., 1826. In repute as a remedy for the bite of the viper. Shec. Fl. Carol, 151-"Possesses sudorific, vulnerary, anti-epileptic and anti-hydrophobic virtues." Lind. Nat. Syst. of Bot., 224-_"Really possesses highly energetic powers: for Orfila destroyed a dog by making him swallow three drachms of the extract." Op. cit. Woodville states that it is acrid and poisonous. Used as a local application in ill-conditioned ulcers, and internally in visceral obstructions, dropsy, epilepsv and mania.

Anaromeda mariana.-U. S. Disp., 1228, app.; Mer. \& DeL. Dict. de Mat. Med., t. I., 289 ; Coxe Am. Disp., 84; Shec. Fl. Carol., 156. Employed in domestic practice; remedy for herpes, \&c.; as a wash for ulcers to which negroes are liable.

And-nitida, (Sorrel tree, Male whortle-berry.)-Ell. Bot. Med., note I., 493. A decoction of leaves used in the cure of itch.

And-arborea, (Sorrel tree.)-U. S. Disp., app. 1227. Leaves; when chewed, allay thirst.

And-speciosa.-.U. S. Disp., app. 12\%8. Said to be a powerful errhine.

Apoynum cannabinum, (Indian hemp.)-Pe. Mat. Med., II., 365 ; Jour. of Phil. Coll. of Pharm., V., 136; Am. Jour of Med. Science, XII., 55 ; Dr. Griscom, in Op. cit., U. S: Dis., 108; Am. Med. Rev., III., 197; Bell Pract. Dict. of Mat. Med., 61: Ball. \& Gar. Mat. Med., 333; Merat \& DeL. Dict: de Mat. Med., t. I., 363. Used in domestic practice in St. John's; called, by the negroes, Gen'l. Marion's weed, from its having been a favorite remedial agent in his carnp; a powerful emetic and cathartic; promotes diaphoresis and expectoration. "Decoction acted as a powerful hydragogue cathartic, and completely cured an aggravated case of ascites."

Arachis hypogea, (Ground nut.)_Shec. Fl. Carol., 191. Said to possess aphrodisiac properties. "English Physician," by Nich. Culpepper, p. 85.

Aralia spinosa, (Prickly ash, Hercules club of the negroes.)Ch. Mat Med., II, 231; Fr. Elems., 20; Ell. Bot., 373 ; Mer. \& DeL. Dict, de Mat. Med., t. I., 379; Coxe Am. Disp., 100; Shec 
Fl. Carol., 191. Used in lnes renerea. The rattle snake's master, par excellence of the negroes; they rely upon it almost exclusively as a remedy for the bite of serpents. I have been informed by one who possessed some local reputation as a leech, that he administered the bark of the root in sulstance; from him has been derived some information concerning plants used in domestic practice, and also those derived from the Indians. Merat salys that it is employed in rhemuatism, to allay pain cansed by carions teeth, and in violent colics. "Probably to be preferred to any emetic yet discovered, among onr native plants."

Archangelica triquinala, (Angelica lucida of some authors.) -Lee. Mat. Med., L, 85; U. S. Disp., 98; Wondv. Med. Bot., S6, 35 ; Jomrn. de Pharm., 3, ser. 2, 12.4: Pe. Mat. Med. and Therap., II., 469; Lid \& Vav. Mat. Med., 276; Mer. \& DeL. Dict. de Mat. Med., 1. I., 297; Shec. Fl. Carol., 167. This posesses more aroma than any of our indigenous plants; used in spasmodic vomiting, thatulent colics and nervons head-aches; some say it is powerfully emmenagogue.

Argemone Mexicana, (Prickly Poppy.)-Me. \& De. L., Dict. Univ. De. Mat. Med. 'T. 1, 395 ; Jour. de Pharmacie, XIV, 73 ; Bull. des. Sc. Med. de Ferus VIII, 210; De Caud. Essay, 116. The negroes of Senegal use a decoction of the root in Gionorrhœa. In Java, they employ it in inveterate cutanenus diseases, and as a caustic in Chancres. In the Indies, in Opthalma and Coup de Soleil. "The flowers are narcotic, and the seeds may be substituted for Inecacuanha." See the Dict. de Mat. Med. A more careful examination of this plant might well repay the labor bestowed upon it.

Aristolochia Serpentariu. (Small or Virginia Suake Root.) Ed. \& Vav. Mat. Med.. 249 ; Ed. Mat. Med. and Therap. I., 250; Trous. \& Pid. Mat. Med., I. 336; Le Mat. Med. I, 163; Fr. Elems., 5:20 ; Bell's Pract. Dict. Mat. Med., 420 ; Royle Mat. Med., 532 ; L. S. Disp. 658; Pe. Mat. Med. \& Therap. I, 231; Journ. de Pharmacie, VI., 365; Jour. de Chimie, Med. T. VII., 493; Sydenham, Peechey's Trans. 4 Ed. 33 ; Ball. \& Gar. 375 ; Cull. Mat. Med. II, \$5; Bergii Mat. Med. II, 765 ; Mer. \& de L. Dict. de Mat. Med. t. I., 415 ; Big. Am. Med. Bot. III., S2; Murray, App. Med. I., 34S; Chap. 'Therap. and Mat. Med. II., 411 ; Lind. Hot Climates, 101 , 254; Shec. Fl. Carol. 203; Lindley's Nat. Syst. of Bot., 206: Barton's Med. Bot. II., 51 ; Woodv. Med. Botany. Well known as a tonic and diaphoretic-of great value in the treatment of 'Typhus fever, in Chlorosis, atonic affections of intestinal canal ; indicated where we wish to stimulate, and excite at the same time a free diaphoresis and diuresis. It pronotes the cutancous secretions in exanthematous diseases, where the eruptions are tardy. Used 
very considerably among the negroes on the plantations. Its effects are increased by uniting with camphor.

Arum Tryphyllum, (Wake robin-Indian turnip.)-Chap. Therap. II, 41; Matsou's Veg. Pract., 295. Thomson also in the Steam practice. Eb. Mat. Med. \& Therap. II., 437 ; U. S. Disp. 123 ; Pe. Mat. Med. II., 78; Big. Am. Med. Bot. I., 52; Am. Jour. of Pharm. XV., 83; Thacher's JU. S. Disp, Art. A triphyllum, 153 ; Cullen's Mat. Medica II., 211 and 554; Mer. de L. Dict. de Mat. Med. t. 1, 460; Caxe. Anı. Disp., 121; Big Am. Med. Bot. I., 52 ; Schoepf. Mat. Med., 133; Op. Cit. Rush II., 30 ! ; Barton's Coll. to form. of Mat. Med., 29; Shec. Fl. Carol., 273; McCall in Phil. Med. Jour. II, 84; Cutler's Am. Acad. I., 487 ; Lind. Nat. Syst. of Bot., 364. "Milk in which the acrid principle of the A. tripyllum has been boiled, has been known to cure consumption!" De. Cand. cit. in Lind. In the Nat. Syst. Bot. p. 364. Lindley remarks of some of this class, "That the spadines disengage a sensible quantity of heat when they are about to open." Agardh, considers that the acrid principle, which notwithstanding its fugacity, has lately been obtained pure, is of great power as a stimulant. In corroboration, I would mention that I have produced vesication merely by plar cing a small portion of the stem of the Arum Walteri, in contact with the unbroken skin, both species are very irritating to the Fauces. The root sliced, used as an application for poison from the ivy. "In the chronic asthmatic affections of old people, it is a remedy of very considerable value." According to Dr. Thacher of approved efficacy in Rheumatism, and aphthous sorethroat.

Asarum Canadense, (Wild ginger.)-Pe. Mat. Med. II., 234 ; Fr. Elems. 220; Ám. Jour. of Pharm. X., 186 ; Dict. Univ. des drogues simples, An., 1733 ; U. S. Disp., 125; Cull. Nat. Med. II., 473-553; Me. and De. L. Dict. Univ. de Mat. Med. t. I., 463; Big. Am. Med. Bot. I., 149 ; Schoepf. Mat. Med. 72, in op. cit. Barton's Coll. to Mat. Med. 26,4S; Coxe's Arn. Disp. 368; Lind. Nat. Syst., 206. A stimulant and diaphoretic "applicable to similar cases with serpentaria." Used among the people as a substitute for ginger. A friend, who has employed it to some extent on his plantation, informs me that in large doses it is a never failing emetic. More than a teaspoonful of the root taken in warm water at a dose.

A Virginicum, (Heart Snake Root.)-Fr. Elems. 219; Shec. Fl. Carol. 218. "As a stimulating diaphoretic, fully equal to the aristolochia serpentaria."

A. Arifolium.-Shec. Fl. Carol. see A. Eucopeum, 217. An emetic and errhine, used in paralysis of mouth and tongue.

Asclepias tuberosa, (see A. decumbens of some authors; Pleurisy Root, Butterfly weed.)-Pe. Mat. Med. and Therap. II., 347; 
Chap. Mat. Med. and Therap. 1, 351; U. S. Disp., 127; Ed. \& Vav. Mat. Med., 315: Eb. Mat. Med. II., 219; Eill. Bot. I., 326 ; Big. Am. Med. Bot. II, 65; Thacher's Disp. Art. A. tuberosus, 154 ; Bart. Med. Bot. 1, 244; Lind. Nat. Syst. 304; Am. Med. Record. III., 334: Chap. Therap. and Mat. Med., 3\$9; Fr. Elems. 217; Bell’s I'ract. Dict. Mat. Med., S2; Cull. I., 6; Me. Et de L. I ict. de Mat. Med. t. 1, 467; Prodr. 458; An. 1810; Shec. F\%. Carol. 220); Bart. Coll. Mat. Med., 48; Lind. Nat. Syst., 304. Used in Dysentery, and as an eschacotic for fungous growths. Diaphoretic sudorific and purgative; "has the singular property of exciting general perspiration without increasing in any perceptible degree the heat of the body." (Lindley see A. decumbens.) Of some value in Rheumatism, Catarrh, subacute Pnenmonia, and in Phthsis as a palliative. Dr. Macbride, experimented very largely with this plant.

Asclepias Verticillata, (1)warf Milkweed.) - Domestic remedy in repute for bite of snakes. This is said in be very deservedly celebrated by those who have used it in the upper districts of South-Carolina.

Asparagus officinalis, (Grows wild on banks of Cooper River.)-U. S. Disp. 1230 App.; Ed. \& Vav. Mat. Med., 318, \&c.

Aster tortifolius. - Used in domestic practice.

Baccharis halimifolia, (Sea Myrtle, C'onsumption weed.)Shec. Fl. Carol, 256. 'This plant is of undonbted value and of very general use in domestic practice as a palliative and demulcent in consumption and cough. "The Bark is said to exude a Gum so much resembling honey, as to attract hees in great numbers." Shec. loc. cit.

Baptisia tinctoria, (Wild Indigo.)-Barton's Med. Bot. II., 57 ; U. S. Disp., 1231 ; Lind. Nat. syst. Bot. 153. In large doses a cathartic and emetic, roots and herbage possess antiseptic properties. Dr. Comstock, speaks highly of its eflicacy in threatened or existing mortification-virtues reside in cortical part of the root. Eberle uses a decoction in aggravated cases of ulcerated Umbilicus; see "Diseases of children," p. 98.

Berberis canadensis, (Barberry.) -U. S. Disp., 1233 App.; Lind. Nat. Sys. Bot. 30 ; Shec. Fl. Carol, (see B. vulgaris,) 268. Domestic remedy for Jaundice. Root used as a yellow dye. The irritability of its stamens is very remarkable. It is said to have a singular effect upon wheat growing near it, turning the ears black for 50 or 100 yards around.

Bignonia caprenlata.-Shec. Fl. Carol., 275, (see B. Setigera.) A detergent and alterative, very similar to sarsaparilla.

Buseus sempervirens, (Box.) -Ed. \& Vav. Mat. Med., 512; Le. I., 244 ; Bergii. Mat. Med. II., 799.

\section{Cactus.-See Opuntia.}


Callicarpa Americana, (French Mulberry.)-Dray. View. S. C., 62. Said to be useful in dropsical complaints.

Callitriche Verna, (Water chick weed.)-Shec. Fl. Carol., 326. Domestic remedy in dropsy.

Caprifolium.-See Lonicera.

Catalpa Cordifolia, (Catalpa.)-U. S. Disp., 1240; Journ. Phil. Coll. Pharm. VI., 352; Shec. Fl. Carol., 276. See Bryonia catalpa. Decoction used by Japanese in Asthma.

Capsella Bursa pastoris.-See Thlaspi Le. Mat. Med. I., 243 ; Bergii. Mat. Med. II., 589 ; Me. \& de L., Dict. de Mat. Med. t. Vi., 732.

Cassia chamaechrista, (Cassia.)-Me. \& de L. Dict. Univ. de Mat. Med., t. II., 129. Leaves are purgative

C. Occidentalis.-Me \& de L. Dict. de Mat. Med.t. II., 130 ; Marcgrave in his Hist. of Brazil, mentions it as a remedy against the poison of venomous animals, and in strangury. It is also useful as an application in inflammation of the anus, and erysipelatous eruptions. Merat. Lnc. cit,

Castanea pumila, (Chinquapin.) -U. S. Disp., 189. Bark employed in the cure of intermittents, of no great value.

Cermothus Americanı, (New-Jersey Tea tree.)-Ferrein Mat. Med. III., 335; U. S. Disp., 1240 App.; Ell. Bot. 291; Boston Med. \& Surg. Journ., 1835; Lind. Nat. Syst., 108; Me. \& de L. Dict. de Mat. Med., t. II., 165. An astringent in gonorrhœal discharge. Mr. Tuomey informs me, that great use is made of it in domestic practice in Chesterfield district, S. C. An infusion of the leaves was employed during the Revolutionary War, as a substitute for tea. I have experimented with the green leaves, and obtained a liquor somewhat resembling common tea, both in color and taste. Referring to its antisyphilitic powers, Ferrien says, "Elle guerit aussi en moins de quinze jours les veneriens les plus invétérés." The Iudians used it in diseases of this class.

Celtis occidentalis, (Sugar berry.)-Me. \& de L. Dict. de Mat. Med. t. II., 170 ; Flore. Med. I., 90. A febrifuge.

Centaurea benedicta, (Blessed thistle.)-Trous. et Pid. Mat. Med. and Therap. t. I., 253; Thompson Steam Pract. ; Ed. \& Vav. Mat. Med., 179 ; U. S. Disp. 196, Le I., 202; Pe II., 408; Woodv. Med. Bot. 34, t. 14; Ann. de Therap. An. 1943, 206 ; Bergii M. Med. I., 747 ; Me. and de L. dict. de Mat. Med. t. II., 171; Used in Dyspepsia, chronic Diarrhœa and Gout. Woodv. loc cit. "It possesses marked tonic properties." A large dose of decoction is emetic. It is employed as a febrifuge, in dyspepsia, pleurisy and chronic peripneumony. Ed. \& Vav. loc. cit.

Cephalanthus occidentalis, (Button Wood.)-Ell. Bot $1 S 7$. Dray. View. S. C. 62 ; Me. \& de L. Dict. de Mat. Med. t. II., 176; Shec. Fl. Carol. 376 . Decoction used as a wash in palsy, 
E:lintt states that the inner bark of the root is frequently employed in obstinate coughs. loc. cit. sup. Mérat notices it as an anti-venereal.

Cerasus serotim, (Wild Cherry.) - See prunus of some anthors.) U. s. Disp.. 57ti: Journ. Phil. Coll. Pharm. X., 197, and XIV., 27: Ball's Pract. Dict., 359; EL. Mat. Med. of Therap., 3100; Pe. Mat. Med. \& 'Therap. II., 538; Le. II., 457. Phil. Trans. No. 418; Michaux N. Am. Sylv. II., 20.5; Ball. \& Gar. Mat. Med., 273 ; Cull. M. Med 258; Lind. Nat. Syst. Bot. 147; Woodv. Med. Bot. (P. laurncerasus,) Leares sedative and antispasmodic. Coughs. Angina Pectoris, de. Adapted to dyspepsia with neuralgic symptoms. Dr. Eherle states that the cold intusion had the eflect of reducing his pulse from it to 50 strokes in the minute.

Chenopodium botrys. (Worm Seed, Jerusilem Oak.) - I.e. I., 23.5 : Ed. \& Vav. Mat. Med., 304; U. S. Disp. 206; Bergii Mat. Med. I., 191; Me. de de I. Dict de Mat. Med. t. II., 225; Shec. Fl. Carol. 358. An infusion administered in hysteria, chronic catarhs and humoral asthma.

Chenop. album.-Mer. \& DeL. Dict. de Mat. Med., I. II., 223; Phys. Med. 'Trans., Calculta, II., p. 40. A sedative and diuretic. Heinorrhoids.

Chenop. anthelminticum, (Jerusalem nak.) - Eb. Mat. Med., 215; Pe.. II., 27. ; EII. Bot., I., 331 ; Chap. Therap. and Mat. Med., II., T1; Dray. View S. C., 65; Fr. Elems., 191; U.S. Dis., 201j: Bart. Med. Bot., II.. 183; Am. Journ. Pharm., V., 1S0; Bergit Mat. Med., t. I., 183. Well known as "one of the most efficient indigenous a!nthelmintics," adapted to the expulsion of lumbrici in children. It is employed on plantations to a considerable extent.

Chelone glabra, (Snake head.)-Mat. Veg. Pract., 215. Administered as an anthelmintic; in jaundice, hepatic disorders and constipation.

Chemaphila maculata.-('The C. mac. and Pyrola maculata have been sometimes confounded, and the references apply to either, both commonly called Pipsissewa, Winter-green.)-Chap. Therap. and Mat. Med., I., 313; Eb. Mat. Med., II., 321 ; Ell. Bot., 50.5; Fitt. Man. Bot., 210; Bell's Pract. Dict.. 12S; Mitchell's Inallg. Thesis, 1503; Ed. \& Vav. Mat: Med, 320): Pe. Mat. Med., II , 380 ; U. S. Disp., 208; Bart. Coll. to form. Mat. Med., pt. II., 21; 3d Fd. Lind. Nat Syst. Bot., 219. A diuretic-root and leaves used as a wash for sores and ulcers. It has been successfully administered in ascites, in acute rheumatism, and in various intermittent disorders, and is useful in a variety of cases of gravel, strangury and hamaturia. The Indians regarded it as of universal efficacy-loc. cit, 
Chionanthus virginicr, (Fringe tree.)-Ell. Bot., 6. An irfusion of the root given in long standing intermittents.

Chrysanthemum leucanthemum, (One-eyed daisy.)-Shec. Fl Carol., 394; Mer. \& DeL. Dict. de Mat. Med., t. II., 271; Nouv. Jour. de Med., V., 208. Administered in leucorrhoea.

Cicuta maculata, (Hemlock.)-Mer. \& DeL. Dict. de Mat. Med., t. II., 292 ; Big. Am. Med. Bot., I., 125 ; Schoepf. Mat. Med, 36 -in op. cit. ; Bart. Coll. to form. of Mat. Med., 13, 46; Stockbridge New Eng. Journ, III., 334; Mitchell, Ely \& Muhlenberg Med. Repos., XVII., 303. This plant has repeatedly occasioned the death of those mistaking it for others. It is a narcotic poison, used as a substitute for conium. The vegetable acids, lemon juice and vinegar, neutralize its effects. Strong tea and coffee are the best antidotes for the stupor which follows its employment.

Clematis crispa.-Mer. \& DeL. Dict. de Mat. Med., t. 1I., 311; Shec. Fl. Carol., 418. A dangerous vegetable caustic, acting as a substitute for cantharides; also applied to rheumatic limbs, paralysis and gout. See C. vitalba.

Collinsonia scabra, (Rongh-leaved collinsonia.)-Mer. \& DeL. Dict. de Mat. Med., t. II., 364. Possessed of properties analogous to the C. canadensis. Tonic astringent and diuretic; the latter, says Merat, has some reputation in dropsy of the ovaries, catarrh, and inflammation of the bladder. ("Catarrh de la vessie.")

Commelina communis.--Mer. \& DeL. Dict. de Mat. Med., t. II., 372.

Convulvulus panduratus, (Wild Potato vine.)-Barton's Coll.g pt. II., 49 ; U. S. Disp., 269; Ell. Bot., I., 254; Mer. \& DeL. Dict. de Mat. Med., t. II., 409 ; Coxe Am. Disp., 226 ; Lindley's Nat. Syst. Bot., 231; Bart. Med. Bot., I., 252. Used as a substitute for jalap. Diuretic. In the form of infusion, said to be very serviceable in calculous complaints. See the investigations of Dr. Harris.

\section{C. battatus.-See Shec. Fl. Carol., 434.}

Cornus florida, (Dog-wood.) - Eb. Mat. Med.g 303; Chap. Therap. and Mat. Med, II., 438 ; Ell. Bot., I., 208; Dray. S. C.g 63 ; Bell's Pract. Dict., 152; Pe. Mat. Med., II., 753 ; U.S. Dis.g 277 ; Ed. \& Vav. Mat. Med., 197 ; Am. Jour. Pharn., VII., 114 ; Royle Mat. Med., 422; Ball. \& Gar., 310 ; Mer. \& DeL. Dict. de Mat. Med., t. IV., 436; Big. Am. Med. Bot., II., 73; Shec. Fl. Carol., 449 ; Walker's Inaung. Dis. Phil., 1803; Bart. Coll. Mat. Med., 12; Thacher's Disp., 203 ; Lind. Nat. Syst. Bot., 49 ; Fr. Elems. Possessing properties very nearly allied to those of cinchona. In intermittents, one of the most useful of our indigenous plants; generally given in conjunction with a few drops of laudanum. It has, also, some antiseptic powers.

Cornus stricta.-Shec. Fl. Carol., 449. 
Cretagus crus galli.-Mer. \& DeL. Dict. de Mat. Med., t. II., 460 .

Cyrilla racemiflara.-Eill. Bot., I., 59.5. Used as a styptic, and applied to ulcers, where the indication is to cicatrize them.

Cucurbila lagenaria, (Gourd, Calabasi.)-Ed. \& Vav. Mat. Med., 563; Le. Mat. Med., I., 379; Mer. o DeL. Dict. de Mat. Med., t. II., 492. An infusion in inflammation of the uriuary passages.

Cupressus distycha, (Cypress.)-Shec. Fl. Carol., 481.

Cuscula americana, (Love rine.) - Mer. \& DeL. Dict. de Mat. Med., t. II., 527, in op. cit.; Flore Med. des Antilles, II., 334; Shec. F.l. Carol., 45.5. Imparts a yellow dye to cloths. Said to be laxative and hydragogue.

Datura stramonium, (Jamestown weed, Thorn apple.)--Trous. et Pid. Traite de Therap. et de Mat. Med., t. I., 230; Jour. Univ. des Sc. Med., t., 46, 22t; ; Orfila Traite de Toxicol.; Ell. Bot., 276 ; Dray. S. C., 63 ; Ediub. Med. and Surg. Journ., VII. and VIII., an. 1S12; 'Trans. Med. Chirnr. Soc. Edinb., 1., 2S5; Archives generales de Medecine, t. 14, 373; Med. Chi. Trans. London, VIt., aun. 1S06; Bell's Pract. Dict., 434; Fb. Mat. Med., II., S0; Ed. \& Vav. Mat. Med., 438; Pe. Mat. Med., II., 309; Fr. Elems.. 460 ; U. S. Dis., 65s; Watson's Prat. Physic, 197 ; DeCand. Phys. Veg., I., 354; Bayle. Bibl. 'Therap., t. II. ; Big. $\Lambda \mathrm{m}$. Med Bot., I., 17; Wrodv. Mled. Bot., 197, 74; Traite de Chimie., VI., 319 ; Paris Pharm.; Barton's Essay, Form. Mat. Med, 48; New Eng. Med. and Surg. Journ., IV., 2206; Med. Chirurg. Trans., VII., 2 ; Ball. \& Gar., 316 ; Cull. Mat. Med., II , 2S1; Bergii Mat. MIed., I., 122 ; Mer. \& DeL. Dict. de Mat. Ned., t. II., 593; Bull. des Sc. Med. Ferusac, XI., 197; Ludenstolpe "De Venenis," 531, in Op. cit.; Sauvage's Nosol., II., 430; Greding in Ludwig's "Adversaria," I., 345 ; Murray A pp. Med., I., 6r0; Fowler in Med. Com., V., 161 ; Adhelius cit. in Med. Com. Phil. Trans. Abr., VI., 53; Rush in Phil. Trans., I., 3S4; Schoepf. Mat. Med., 24; Wedinburg in Med. Comment, III., 18; Beverly's Hist. Virg., 121 ; Med. and Phys. Jour., XXV. XXVI.; Conper in Caldwell's Theses, vol. I ; cit in Big. Am. Med. Bot.; Shec. F'. Carol., 497 ; New-York Med. Repos., II., 27 ; I ind. Nat. Syst., 294. "Lsed in Opilepsy, and mania without fever." Lind. loc. cit. A well known narcotic and antispasmodic, employed in astıma, mania, epilepsy, chorea, tetanus, and palsy. Eberle states that the results of his trials with it in rheumatism were exceedingly flattering. He used it in cases of sciatica with entire success; also, not without benefit in dysmenorrhoca. An ointment made of the leaves affords relief when applied to painful and irritable ulcers and hemorrboidal tumours.

Dancus carota.-Woodv. Med. Bot. Royle. M. Med., 401, 416. Antiseptic and diuretic, applied in the form of a ca- 
taplasm to ill conditioned ulcers, and in anasarcous swellings of lower extremities, in suppression of urine and painful micturition. See also Eberle on "Diseases of Children," p. 110.

Daucus pusillus.--Bell's Pract. Dict., 162 ; Eb. Mat. Med. \& Therap. II., 31S. Seeds recommended as a diuretic in cases of gravel and suppression of urine.

Diospyros virginiana, (Persimmon.) -U. S. Disp., 302 ; Ed. \& Vav. Mat. Med., 135; Am. Journ. Med. \&c. N. S., IV., 297 ; Me. \& de L. Dict. de Mat. Med. t. II., 657 ; Coxe's Am. Disp., 259 ; Ann. Chim. de Montp. XXIV., 274; Shec. Fl. Carol., 510 ; Lind. Nat. Syst. Bot., 227. It imparts a black dye; an astringent and styptic, bark used in intermittent fevers, and as a gargle in ulcerated sore throuts. The unripe fruit has been employed advantageously in diarrhoea, chronic dysentery, and uterine hemorrhage.

Discopleura cappillacen, (Bishop weed.)-Shec. Fl. Carol. 136. See Ammi Magus.

Drosera rotundifolia, (Sun dew.)-Shec. Fl. Carol, 519 ; Me. \& De. Lens. Dict. De Mat. Med, t. II., 690. Some of this genera are acrid and corrosive.

Echites difformis.-Me. \& de Lens. Dict. de Mat. Med., t. III., 51. Used as a wash for freckles with milk; juice suffciently caustic to destroy warts and scirrhous excrescences; any portion of the plant will coagulate milk.

Evigeron canadense, (Colt's tail.)-Matson's Veg. Pract., 368; Royle's Mat. Med., 447 ; U. S. Disp., 316 ; Me. \& de Le. Dict., de Mat. Med., t. III., 140 ; Journ. de Bot.IV., 4S; et. des Pharm. 214 ; Coxe. Am Disp., 268. A stimulant, tonic, and diuretic, in high estimation among the steam practitioners as a remedy for dysentery, the herb steeped in hot water, and a tea cup full of the infusion given every two hours; when chewed it relieves cholera morbus. From the observations of Dr. De Puz, (quotéd in U. S. Disp., ) it has been found useful in dropsical conılaints and diarrhoea.

E. Pusillum.-U. S. Disp. 316.

E. Philadelphicum.-Shec. Fl. Carol., 537 ; Royle Mat. Med., 447 ; Barton. 1, 234 ; Lind. Nat. Syst. Bot., 253. A diuretic, in repute as a remedy in calculus, an Nephritic diseases; it has been employed with advantage in dropsy, and by Dr. Wistar, is recommended in hydrothorax, complicated with gout.

Eryngium aquaticum, (E. Yuccifolinm of some Bot, Button snake root.)-Barton's Collections, Ell. Bot., 1, 343 ; Fr. Elems., 280 ; U. S. Disp., 31S; Me. \& de L. Dict. de MIat. Med., t. III., 145; Coxe. Am. Disp., 268; Shec. Fl. Carnl. Art., "Button snake root," 310,545 . The root when chewed, sensibly excites a flow of saliva; decoction is diaphoretic expectorant, and sometimes emetic. Elliott says it is preferred by some physicians, 
to the Sencear snatie root. Dr MC Bride introduced this into popular practice in St. John's, where it is used to some extent.

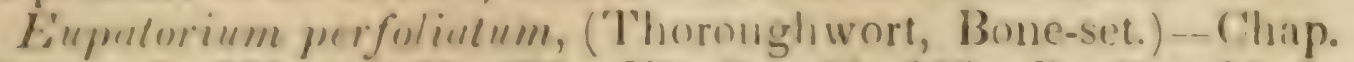
'Therap. I.. 357, and II., 135; I'll. But. II., 303; Pe. Mat. Med., 3-9; Fr. Elenss, 216; Vi. Mat. Med. II., 216; Bell's Pract. Dict. 197 ; Royle Mat. Med., 145; U. S. Disp., 319; Ed. \& Vav., Mat. Med. 197; Bigr. Am. Med. Bot, 1, 3.1; 'Thacher's Am. Disp., 2017; A11. Med. Record. 11I., 3:31; Barton's Lssaly to M. Med., 24; Ball. \& Girr. M. Med. 315; Schoepf. M. Med., 121; Finhrie in Amal. Med. III., 103. Anderson's Inangural 'Thesis, Me. d de 1. Dict., de Mat. Med., t. III., 17\%; Coxe's .m. Disp., 271: Slee H. Cirol., 519 ; Barton:s Med. But. II., 1333; Lind. Xat. Syst. Bot., 253. lery extensirely used antong the negroes on the flantations ats a tonic and febrifuge; it is emetic, sudorific aud daphoretic; repeatedy prescriled will adrantage in rheumalism. dropsy, and in the influenza. which prevailed at the Xorth, atud which was described hy Dr. Rush; from its action on dhe catpillaries it has been recommended in chronic cutancous affections, and has heen found efficacions in typhoid, and in yel low fever.

Ëир. purjmrem, (1)rple Thoromohwort.)-U.S. Disp, 319, Me. L de I. Dict. de Mat. Med., t. III, $17 \%$; nne of the popular remedies for calculus.

İll\%. verbenuefulimm.-U. S. Disp., 320. Tonic, diaphoretic diurefic and aperent; see Dr. Jones' experiments - a popular remedy in intermittents.

Iilip. rotundifolium.-Me. \& de L. Dict. de Mat. Med. t. III., $17 \%$; Jour. (ien. de Med., XXXVI., III. See Dr. Michell's Let. ter. Iufusion said to be useful in consumption.

Firphorlia carollala, (Wild Hippo.)-Bell's Pract. Dict., 199; U. s. Uisp. 321; Fr. Elems, 22; Am. Journ. Med. Sc. XI., 2.2: Biz. Im. Ifod. Bor. III, 119; Royle Mat. Med., 5.12; Me. \& de L Mret. de Mit. Med., t. III., 179; Clayton Phil. Trans., Abr. VII., 331; Zollichoffer Mat. Med., 1S19; Cit. in Bart. Ioc. sup. : Coxe's Am. Disp., 272; said to resemble in its effects the E. ipecactianha-emetic diaphoretic and cathartic. 'The contused ront, iccurding to the experiments of Dr. Zollickofrer, will excit- inflamuation and vesication. Of the root in powder, 15 granss will prodnce emesis. "Combined with opium and the sulphate of potass, an excellent diaphoretic in dropsy." Dr. McKeau, says 12 graitus of root has double the purgative power of an refuat quantity of Jalap. See Dict. Mat. Med. Lonc. cit.

Émphorbia muculata.-Me. \& de I. Dict., de Mat. Med. t. 1II., 151; Ainslie Mat. Ind. II., 76). Juice emploved with great eflicacy in clearing the corriea of the spots and peilicles, (les pellicules, following small pox. Merat says the ancients recom- 
mended the Euphorbiaceæ in diseases of the eye. Dict. de Mat. Med.

Fagus sylvatica, (Beech.)-Shec. Fl. Carol., 559.

Gelseminum sempervirens, (Jessamine.)-Ell. Bot. 312, Med. Note. Flowers and root are narcotic; a spirituous tincture of the root has been used successfully in Rheumatism.

Gentiana ochroleuca.-Ell. Bot., 340.

G. catesbceil, 'Sampson's Snake root.)-Bell's Pract. Dict.21S; U. S. Disp., 348 ; Me. et de L. Dict. de Mat. Med., t. III., 361 ; Coxe's Am. Disp., 304 ; Big. Am. Med. Bot. II., 133; (Sampson Suake Root,) an excellent bitter tonic used with decided advantage in pneumonia and dyspepsia. Dr. McBride found it very invigorating to the stomach. A popular remedy on the plantations.

Geranium maculatum, (Crane's Bill.)_Bell's Pract. Dict., 218; Eb. Mat. Med. I., 382; Big. Am. Med. Bot. 1, 89. Thacher's Am. Disp., 224; U. S. Disp., 350 ; Royle Mat. Med., 573 ; Bart. Med. Bot. I., 149 ; Pe. Mat. Med. and Therap. II., 751; Am. Jour. Pharm. IV., 90; Jour. Phil. Coll. Pharm. I, 171; Ed. \& Vav. Mat. Med., 135; Schoepf. Mat. Med, 107; Bart. Coll. 7 ; Cutler Mem. Amer. Acad. I., 469 ; Me. \& de L.'Dict. de Mat. Med., t, III., 369 ; Coxe's Am. Disp., 304 ; Jour. de Pharm. XIII., 287 ; Lind. Nat. Syst. Bot., 137. A strong astringent adapted to passive hemorrhages, chronic diarrhœa, and cholera infantum. It is injected in cases of gleet and leucorrhœa, and used as a wash for old ulcers. Bigelow speaks of it as a nowerful astringent, and recommends it as a substitute for the imported and more expensive articles of that class.

Guaphalium polycephalum, (Cat foot, Life everlasting.) Matsons' Veg. Pract., p. 275; U. S. Disp., 1255. "Pıobably possesses little medical virtue," a popular remedy in hemorrhagic affection, and as a fomentation, in bruises and languid tumours. Infusion employed by steam practitioners in fever, influenza, fluor albus and consumption.

Gosypium herbaceum, (Cotton.)-Pe. Mat. Med. II., 659; U. S. D. 357 ; Med. and Surg. Journ. XIII, 215, An. 1S2S; London Med. Gazette, Nov. Sth, 1839 ; West. Journ. Med. \& Surg. Aug., 1840; Royle's Illustrations, S4, \& Mat. Med. 288; Me. \& De L. Dict. de M. Med. art. G. herbaceum, t. III., 409; Marcgraves Braz., 60; Dict. de Sc. Nat. XXXIV., 15. See Me. et de L. for references. Decoction of flowers used as an emollient in diseases of the urinary organs. In Brazil the leaves are employed against the bite of scorpions and vipers, and, macerated in vinegar, are applied to the head in hemicrania. Dict. de Mat. Med. loc. cit.

Gonolobus macrophyllus. Ell. Bot. I., 328: Me. \& de L. Dict. de Mat. Med. t. III., 409; Ann. du Museum, XIV., 464 ; 
Mérat says, "Cette apocyneé des ctats-unis passe pour fournir le suc avec lequel les sauvanes de ce pays empoissonnent leurs fleches." One of the substitutes for colocynth.

Hanmelis vircinica, (Witch hazle.)-Matson's Veg. Pract. 201: U. S. Disp. 1258, App.; Me. \& de L. Dict. de Mat. Med. t. III., 452; Coxe's Am. Disp 310. A sedative and discutient in painful tumours, derived from the Indians-decoction used as a wash in hemorrhoidal affections and onthalmia. 'T'he steam practitioners employ it as an injection in irritable hemorrhoids, and during the bearing down pains of women.

Helonias dioicn, (Common, Blazing star.)-Matson's Veg. Practice, 21S; Ell. Bot. 1., 12:3 ; Lind. Nat. Syst. 319 ; De Cand \& Duby, 473, An. 1528. Infusion anthelmintic. Tincture tonic. Prof. Ives recommends it as efficient in checking nausea and romiting. The Indian women employed this plant in preventing abortion, and it is used by the stean practitioners for debility of digestive organs, in doses of $1 \frac{1}{2}$ tea-spoenful of powder in warm water three times a day. It relieves coughs when chewed.

H. cryth osperma, (Fly poison.) - Ell. Bot. 421. "A narcotic poison, employed in some families to destroy the house fly. Bulbs are triturated and mixed with molasses. The flies unless swept in the fire or otherwise destroyed, revive in the course of twenty-four hours."

Heuchera americana. (Alum root.)--Lind. Nat. Syst. Bot. 163; Bart. II., 162 ; "powerful astringent." 629.

Hihiscus moschentos, (Marsh mallow.)-Bergii Mat. Med. II.,

Hopen tinctoriu. Ell. Bot. II., 177. Its leaves aftord a yel. low dye.

Humulus lupulus. Ed. \& Vav. Mat. Med., 185; Chap. Therap. of Mat, Med. I., 345, and II., 455. Eb. Mat. Med. II., 55; U. S Disp., 374 ; Bir. Am. Med. Bot. III., 163 ; Freake Med. and Phys. Journ. XIII., 432; Thompson's Loudon Disp., 200; Bigshy's Lond. Med. Repos. V. 97 ; Bryorly's Inaug. Diss. Philad. An. 1803. Ives in Silliman's Journ. II., 302; cit in Big.

Hydrocatyle umbellata. Me. \& de L. Dict. de Mat. Med. t. III., 560. Eimployed with great efficacy in Brazil against hypochondriacism. According to one author, the root is sn valuable in diseases of the kidneys, as not to he replaced by any other medicines; emetic, diuretic, and vulnerary. I see no niention made of it in the English or American Mat. Meds.

Hypericum sarothra, (Pine weed, Orange grass.) - (Sere saro. thra gentianoides of Mich.) Me. \& de L. Dict. de Mat. Med. t. VI., 226; Journ. de Med. LXXX., 360. Employed as an aperient in inflammatory affections.

llex cassena, (of Ell. See I. vomitoria of some authors, Cas. 
sena.)-Ell. II., 680 ; U. S. Disp. 1263, App.; Me. \& de Le. Dict. de Mat. Med. t. III., 591 ; see I. vom. A decoction from the leaves, called the Black drink, was employed by the Indians; it is a mild emetic. The Dict. Mat. Med. says it is powerfully diuretic, used in calculus, nephritic diseases and gout. There may be some doubt about the identity of the plant.

\section{I. opaca. U. S. Disp. 1263, App.}

Impatiens noli tangere. U. S. Disp, 1264. A dangerous plant possessed of acrid properties; when taken internally it acts as an emetic, cathartic and diuretic.

Indigophera caroliniana. Not inferior says Nuttal to the cultivated indigo.

Ipomea nil, (Convolvulus of some botanists.)-Me. \& de L. Dict. de Mat. Med. t. IV., 409. Root employed as a purgative by the ancients.

Iris versicolor, (Blue flag.)-U. S. Disp. 405 ; Coxe's Am. Disp. 354 ; Lind. Nat. Syst. Bot. 333 ; Big. Am. Med. Bot.

155 ; Bartram's Travels, 451; Cutler Mem. Am. Acad. 405, 6, cit in Big. Eill. Bot. I., 45 ; Me. \& de L. Dict. de Mat. Med. t. III., 659. Of decided diuretic powers, the base of a popular and valubable receipt for dropsy. See Fr. Elems., 279. Er. McBride held it in high estimation, and extended the use of it in St. John's. It was one of the remedies derived from the Indians.

Juniperus virginiana, (Cedar.)-Pe. Mat. Med. II., 181; Fr. Elems. 195 ; U. S. Disp., 413; Big. Am. Med. Bot. III., 49; Dict. de Mat. Mled. t. III., 698; Michaux's N. Amer. Sylvin. III., 221 ; Am. Journ. Pharm. XIV., 235; Thacher's Disp. 247; Lind. Nat. Syst. Bot. 316. It exerts effects similar to those of savin. Leaves have been successfully employed as an emmenagogue, and as a stimulant and diaphoretic in rheumatism. Big. loc. cit. The cedar apple possesses anthelmintic properties.

Kalmia latifolia, (Calico bush.) -Drayton's View. S. C. 69 ; U. S. Disp., 1269; Ell. Bot. I., 491 ; Big. Am. Med. Bot. I., 133; Kalm's Travels I., 335 ; Bart. Coll. to Mat. Med. I., 18, 48 and II., 26 ; Thacher's Disp., 247 ; Thomas' Inumgural Diss. cit. in Big.

Lactuca elongata. (Wild lettuce.)-U. S. Disp., 421 ; Annuaire de Therap. An. 1843; Woodv. Med. Bot. 75, 31; see L virosa op. cit. Me. \& de L. Dict. de Mat. Med. t. IV., 10. Similar in properties to L. virosa.

Laurus benzoin, (Spice bush.)-Lind. Nat. Syst. Bot., 201; U. S. Disp., 1233 ; Bart., 295. Used in intermittent fever. A highly aromatic shrub.

L. Sassafras, (Sassafras.)-Ed. \& Vav. Mat. Med., 341 ; U. S. Disp., 640 ; Dray. View. S. C., 68 ; Bell's Pract. Dic., 411 ; Eb. Mat. Med. II., 230; Royle Mat. Med., 518; Pe. Mat. Med. \& Therap, II., 253 ; Cull. Mat. Med. II., 200 and 579 ; Big. Am. 
Med. Bot. II., 142; Murray's App. IV., 535; Kalm's 'Travels II. ; Hoffman's Obs. Phys. Chem., 31 ; Clayton's Phil. 'Trans. VIII., 332; Bremane "sassafrasologia" in 16:7, cit in Big.; Woodv. Med. Bot. "Diaphoretic and diuretic in rheumatism and cutaneous diseases." The pith of the young branches, according to Eberle, contains a great deal of mucilage. "An exceedingly gond application in acute opthalmia, and no less useful as a demulcent in catirrhal and dysenteric aflections." Alibert speaks highly of it both in rheumatism and gout.

Lialris scariosa. U. S. Disp. 1273, App. Fimployed in gonorrhœa and as a gargle in sore throat.

L. Spricula. U. S. Disp., 127\%. One of the rattlesnake masters, Dr. Barton, sitid that all the tuberous rooted species of liatris, were active plants. Loc. cit.

L. Squarrosa. U. S. 1)isp. 1273; Journ. de (himie IIedicale V., 419; "y sont usitees contre la morsure des serpens." Me. \& de L. Dict. de Mat. Med. t. IV., 97.

Limpidambar styracilua, (Sweet gumn.)-Pe. Mat. Med. \& Therap. II., 194; Fd. \& Vav. Mat. Med., 303; U. S. Disp 273; Journ. Phil. Coll. Pharm. VI., 190 ; Royle Mat. Med., 562 ; Bergii M. M. II., 798 .

Lirindendron tulipifera, ('Tulip tree.)-Pe. Mat. Med. II., 743 ; Eb. Mat. Med. I., 31) ; U. S. Disp.. 432; Rush in Trans. Coll. Phy. Phil. An. 1798; Carey's Am. Museum XII. ; Barton's Essay form Mat. Med.. 14; Thacher's Disp.: Big. Am. Med. Bot. II., 107: Bart. Med. Bot. I., 92; Journ. Phil. Coll. Pharm. III., 5 ; Ball and Gar. Mat. Med. 190; Me. \& de L. Dict. de Mat. Ned. t. IV., 130; Annal de Chimic t. LXXX., 215; Liud. Nat. Syst. Bot. Younger Michaux on Forrest trees N. Am. Clayton's Phil. Trans. VIII., 332; Rnger's Inang. Diss. 1502. One of the most valuable of the substitutes for Peruvian bark. It is tonic, diuretic and diaphoretic. It has been much recommended in chronic rheumatisin and gout ; according to Thacher, acts with great advantage in the advanced stages of dysentery, and Dr. Foung says that in all the Mat. Medica, he does not know of a more certain, speedy, and effectual remedy for hysteria.

Lobelia cardinalis, (Cardinal flower.)-U. S. Disp. 436 ; Ell. Bot. I., 2tis; Drayton's View. S. C. $7 \tau$; Me. \& de L. Dict. de Mat. Yed 1. IV., 137; De Candolle's Essay, 189; Journ. de Pharm. III., 470; Bart. Med. Bot. II., 150; Lind. Nat. Syst. 236. This plant was used by the Indians as an anthelmintic. Merat says it is employed as a pnison by the negroes at the Cape of Good Hope.

Lonicera sempervirens, (Wond-vine.-L. caprefolium of some Bot.) Me. Ede L. Dict. de Mat. Med. t. IV., 113. It is not 
much used in medicine, but the syrup from the leaves, is given in asthma, and as a gargle in angina tonsillaris.

Lycopus angustifolius, (L. Europeus of Eaton.)-(Water horehound.) U. S. Disp., 437; Ell. Bot., 25; Me. \& de L. Dict. de Mat. Med. t. II., 168; see L. Europ. \& L. Virginicus, also Matson's Veg. Practice, 250. Used by the vegetable practitioners in diarrhœa, atonic conditions of the digestive organs, and as a cleansing wash for sores. It has been highly spoken of, on the continent of Europe, in intermittent fevers. These plants should be experimented with more carefully. The L. Virginicus imparts a black color to linen, wollen and silk. It has been used by some with great success in internal hemorrhage, (see the Dict. de Mat. Med. and U. S. Disp., ) and in phthisis it lessens the force of the circulation.

Ludwigia alternifolia.-Me. \& de L. Dict. de Mat. Med. t. IV., 154. Mérat says that in America, a decoction of the root is employed as an unfailing emetic. Dict. de Mat. Med., Loc. cit. Magnolia glauca, (Bay.)-Pe. Mat. Med. II., 733; U. S. Disp., 442; Big. Am. Med. Bot. II., 67 ; Bart. Med. Bot. I., 77 ; Michaux N. A m. Sylvia II., 8 ; Royle Mat. Med., 24S; Ball. \& Gar., 189, Me. \& de L. Dict. de Mat. Med., t. IV., 193; 'Kalm's Travels, I., 205; Marshall Arbus, 83 ; Humphries Med. Comment. XVIII.: Bart. Essay to Mat. Med., 46 ; Price's Inaug. Diss. Phil. 1812; Cit. in Big. Am. Med. Bot.; "bark of root an excellent tonic ;" Lind. Nat. System, Bot. 16. Berries are of considerable value in domestic practice for the cure of rheumatism. This tree is supposed by many to prevent the water of bays and galls, from generating Malaria. It certainly seems that the water is much clearer in which the Bay tree grows.*

* In that old work on Herbs, (of which we have seen but one copy and that not dated,) entitled the "English Physician, by Nick Culpepper, gent, student in Physic and Astrology;" we have met with a great deal concerning the employment of herbs in medicine; but, from the absence of botanical terms it is impossible to ascertain in many cases what species are intended. In order to show the surprisingly superstitious credence, then placed upon the influence of Astrology, in determining the virtues of, and the times proper for gathering plants, and also the diversity of qualities attributed to them, we will extract a portion of what Culpepper says of the "Bay Tree," "government and viitues." That it is a tree of the sun, and under the celestial sign, Leo, and resisteth witchcraft very potently, as also all the evils old Saturn can do to the body of man, and they are not a few ; for it is the speech of one, and I am mistaken if it were not Mezaldus, that neither witch nor devil, thunder nor lightning, will hurt a man in the place where a Bay tree is. Galen said, that the leaves or bark do dry and heal very much, and the berries more than the leaves; the bark of the root is less sharp and hot, but more bitter, and hath some astriction withal, whereby it is effectual to break the stone, and good to open obstructions of the liver, spleen, and other inward parts, which bring the dropsy, jaundice, \&c. The berries are very effectual against all poison of venomous creatures, and the sting of wasps and bees; as also against the pestilence and other infectious diseases, and therefore put into sundry treacles for the purpose. They likewise procure women's courses, and seven of them given to woman in sore travel of child-birth, 
Mag. grandiflora.-U. S. Disp., 412; Pe. Mat. Med. \& 'The. rap. II., 734; Am. Journ. Pharm. XIV., 95; Me. \& de I. Dict. de Mat. Med 1. IV., 193. "In Mexico, the seeds are employed with success in paralysis." Dict. de Mat. Med. Loc. cit.

Murruhium vulgare.-- Kal. \& Vav. Mat. Med., 273; 'Trous. et. Pid. 'Traite de 'Therap. 308: Watson's Pract. Physic., 332, and 118; Royle .lat. Med., 470; Pe. Mat. Med. II., 284; Le. Mat. Med. II., S9; Matson's Veg. Pract.; U. S. Disp. 452; Ball. \& Gar. Mat Med., 35s; Cull. II. Med. II., 154. Bergii. Mat. Med. II., 555; Woodv. Med. Bot. Leaves tonic and laxative, in asthma, hysteria, and menorrhagic diseases. Ed. \& Vav., cite it as a remedy in catarrhs, peripneumonies aud phthisis.

Maranta arundinacia.-L.S. Disp., 419 ; Royle Mat. Med., 585 ; Bell's Pract. Dict. 48.

Maruta cotula, (see Anthemis of some Bots., Wild Chamomile.)-Ed. \& Vav. Mat. Med., 263; U. S. Disp., 278; Bergii Mat. Med., 1. 1, 741; Me. et de L. Dict. de Mat. Med. 1. 1, 741; Shec. Fl. Carol., 171. A substitute for chamomile, (and Mérat says for assafotida, ) given in numerous diseases; one of our domestic remedies. It also possesses a:ti-hysteric virtues, and is recommended in rebellious bilious fevers.

Melia azedarach, (P'ride of India.) - Mérat \& de L. I)ict. de Mat. Med. t. IV., 290; U. S. Disp. 135; Ell. Bot. 475 ; Chap 'Therap. 11., 70; Bell's Prict. Dict., s7: Rnyle Mat. Med., 308; Eb. Mat. Med., 2017; Fr. Elems. pt. 1st. Archives Génerales de Méd., XVII., 112; Lindley's Nat. Syst. 102; an active vermifuge. Barton considered it our most active anthelmintic; it is also a febrifuge, adapted to verminous levers, where no worms are voided. Thacher states that the pulp of the berry has been employed with success as ain ointment in Tinea capitis. Mérat mentions well alithenticated cases of poisoning from eating the berries in very large quantities; Diet. de Mat. Mled. loc. cit.

do cause a speety delivery, and expel the after-birth, and thetefore not to be taken by such as have not gone their time, lent they pucure aburtion or cause labor wo soon. They wonderfully help all culd and rheumatic disillatims from the brain, to the eyes, lungs, or other parts, and being made intis an Electuary with honey, do leelp the consumption, wl.t coughs, shortness of breath, and thin Rheums, as alos the Megrim. They mughtily expel the wiml and provoke urines, help the mother and hill the worms The leaves also work the litie effects; a hath of the decoction of the leaves and herries, is singulaty good fur women in sit in, that are troullled with the mother, or the dise ses therenf, or the stoppungs of their courses, or for the disciases of the bladcier, panns in liee howels hy winl, and suppong of urine; a decoction sce, settedh the palate of the mouth in its place. The vil made of the herries is very comforable-all colligriefs of the joints, nerves, arteri s, stomach, helly, or womh, and helpeth palsies, convulsions, cramps, aches, tremblings, and numbness in any part, weariness alon, and pains that conne fly sure traveling * * pains in the ears are also cured by dropping in some of the oil, or by receiving into the ears, the fume of the decoction of the berries through a funnel. It takes away the marks of bruises; it helpeth also the itch, scabs and weals in the skin." 
Melothria pendula, (Creeping cucumber.)-Me. \& de L. Dict. de Mat. Med. t. IV., 322; Journ. de Chimie Med. III., 498. Employed as a purgative, some say of a very drastic nature.

Meniha tenius, (Âm. spear mint.)_Matson's Veg. Pract. 286. Said by Culpepper to be an aphrodisiac. "English physician," 214 ; see magnolia glauca. loc. sup. Dr. Thompson says it is a specific in allaying vomiting and nausea.

Mitchella repens, (Mitchella, partridge berry.)-Fil. Bot. Med. Note, 199. An infusion of the stems and leaves, used in dysu ry. Its diuretic powers are not great. Op. cit.

Monurda punctata, (Dotted monarda. Origanum.) Chap. Therap. II., 302; Ell. Bot. 30; U. S. Disp., 462; Am. Med. Record. II., 496 ; Ball. \& Gar. Mat. Med. 360; Me. \& de L. Dict. de Wat. Med.; a stimulant, carminative and highly aromatic plant. t. IV., 444 ; Bull. des sc. Med. de.Ferus. XI., 302; very aromatic. A popular emmenagogue. Chapman mentions a case of long standing deafuess, cured by the oil poured into the ear. It is used in allaying nausea and vomiting, in bilious fever. See Dict. de Mat, Med.

Morus alba, (White inulberry.)-Bell's Pract. Dict. 319; U. S. Disp. 463. Bark a purgative vermifuge. Its properties are not very marked.

M. rubra. U. S. Disp. 463.

Myrica cerifera, (Swamp Myrtle.)-Eil. Bot. II, 678; Matson's Veg. Pract. 198; U. S. Disp., 200; Pe. Mat. Med., 786; Big Am. Hed. Bot., III., 32; Am. Journ. Med. Sci., II., 313 ; Bergii Mat. Medica II., 541 ; Nicholson's Journ. IV., 187, 129 ; Kalm's 'Travels 1, 129 ; Dana in Silliman's Jour. 1; Thacher Disp.. 2s8; Me. \& de L. Dict. de Mat. Med. t. IV., 531; De Candolle's Essay, 272 ; Lind. Nat. Syst. Bot., 180. The powdered root of this plant is used to some extent by the Vegetable practitioners as an astringent in scarlet fever, diarrhœa, dysentery, and as a valuable gargle in sore-throat. The powdered bark of root, according to Dr. Dana, proved powerfully sternutatory. From the berries a wax is obtained, which possibly may be made a source of profit.

Nabalus (Prenanthes alba, Ell., (commonly called gall of the earth.)-Root excessively bitter; used in domestic practice as a tonic.

Napeta cataria, (Catnip.)--Matson's Veg. Pract., Ed. \& Vav., Mat. Med., 276 ; U. S. Disp., 191 ; Le. Mat. Med. II., 130; Bergii Mat. Med. II., 540; Me \& de L. Dict. de Mat. Med. 1. IV., 592. This is a stimulant tonic, employed, as a popular remedy in amenorrhœa, chlorosis, hysteria, the flatulent colic of infants, \&c. Leaves, if chewed, are said to relieve toothache. It is not spoken very highly of by the Dispensatory, said to be employed with succes in hydrophobia. 
Nympheen odoratn, (White Pond Lily.) - Mat. Veg. Pract., 201 : Thrompson's Steam Pract.; U. S. Disp., 1280; Big. Am.

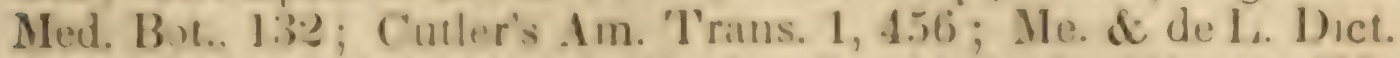
de Mat. Med. t. IV., 613; Ball. des Sc. Med. de Lerusac III. 74. "An anciaphrodisiac" root possesses a high degree of astringency, it is a popular remedy in-bowel complaints, and as an injection in gleet, fluor albus, dc. It also forms an excellent poultice for ulcers. Dr. Thompson employed this plant in the steam practice. Matson says it is useful as a gargle in sore-throats.

Oenothera biennis, (Scabish.)-U. S. Disp., 12S1; Journ. Phit. Cull. Pharm. IV., 292 ; Lind. Nat. Syst. Bot.; "root eatable," Lindley. Dr. Griffith found a decoction of service in eruptive complaints, especially tetter ; loc. cit.

Orchis flara, (Yellow orchis.)-Me. \& de. L. Dict. de Mat. Med., t. V., 92. An aphrodisiac mentioned by Culpepper "English physician," p. 236. Nérat says it has been so regarded in Arabia also. Dict. Loc. cit.; species not well identified.

Orobanch Americana.-U. S. Disp., 1282. Thought to be serviceable in cancer ${ }^{1}$

Opuntia (see Cactus of some Bot.) ructus, (Prickly pear.)Me. \& de L. Dict., de Mlat. Med. t. 11. 6; Shec. Fl. Carol. 319; see C. cochinellifer.

Orontium aquaticum, (Golden club.)-Lind. Nat. Syst., 364. "Seeds are acrid, but become eatable by roasting."

Oxalis vinlacea, (Wood sorrel.)-U. S. 1)isp., 12.

Physalis pubsescens.-Me. \& de L. Dict. de Mat. Med., t. V., 296 ; Journal de Chim. Med. VI., 210. It is supposed that the species bearing this name in Europe and America are different. The former is interesting.

Phytolacca decundrin, (Poke berry.)-U. S. Disp., 537; Bell's Pract. Dic., 3.5.; Big. Am. Med. Bot. 1, 35; Bart. Med. Bot. II., 213; Am. Jour. Pharm. XV., 169; Murray A pp. Med. IV., 335; Kalm's Travels in N. Am. 1, 197; Graffenreid Mem. Berne III., 185 ; Schoepf M. Med., 71; Browne IIist. Jamaica, 232; Amoen Acad. IV.; Miller's Dict., art. Phyt., Sprogel Diss. cir. ven., 24 ; Beckman com. 17r4, 9 ; Allioni Flor. Ped. II., 132; Franklin's Works, I.; Cutler Mem. Am. Acad. 1, 447 ; Rush 1, 259; Thacher's Disp., 300; Shultz Inaug. Thesis; N. Am. Journ. VI.; Journal de Med. de Corvisart Leroux, XVI., 137; An. de Chim. LXII., 71 ; cit in Big.; Me. \& de. L. Dict., de Mat. Med., V; 293; Coxe Am. Disp., 456 ; Lind. Nat. Syst. Bot., 210. The uses of this plant are well known; a remedy for chronic and syphilitic rheumatisin-serviceable in ill conditioned ulcers, pulverised root an emetic; according to De Candolle, a powerful purgative-a strong infusion has been found efficacious in piles. Dr. Wond recommends an ointment in psora and tinea capitis, and a decoction of the berries in scrofula. 
Pinus taeda.-Pe. II., 161 ; U. S. Disp., 709.

P. palustris, (Long leaved pine.)-Pe. Mat. Med. II., 167 ; Bell's Dict., 359 ; U. S. Disp., 709 ; Ball. \& Gar. M. Med.g 399 ; Royle Mat. Med. 564.

Plantago major, (Plantain.)-Le. Mat. Med. II., 232; U. S. Disp., 1289, App.; Ed. \& Vav., Mat. Med., 135 ; Bergii I., 71; Me. \& de L. Dict. de Mat. Med. t. V., 358; Journ. Univ. des. Sc., Ned. XIX., 127. A popular vulnerary, once in great repute, said to have proved useful in intermittents, and many other diseases. It is no doubt possessed of some value as a dressing for blisters, sores, \&c. I have seen it growing in the streets of Charleston.

P. lanceolata, (Rib-wort.)-Le. Mat. Med., II., 232.

Podophyllum peltatum, (Wild Jalap.)-Pe. Mat. Med. II., 749 ; Drayton's View, S. C., 73; Fr. Elems., 137 ; Royle Mat. Med., 573; Bell's Pract. Dict., 373 ; Ell. Mat. Med., I., 205 ; Ed. \& Vav., Mat. Med. I., 514 ; U. S. Disp., 556 ; Big. Am. Med. Bot. II., 34 ; Bart. Mat. Med. I, 9 ; Journ. Phil. Col. Pharm. III., 273 ; Ned. Recorder, III., 332 ; Ball. \& Gar., Mat. Med., 193; Schoeff M. M. S6; Chap. Mat. Med. \& Therap.. 209; Me. \& de L. Dict. de Mat. Med., t. V., 207 ; Coxe Am. Disp., 478; Lind. Nat. Syst. Bot., common in swamps, safe and active cathartic. Dr. McBride made great use of this plant during his practice in St. John's; he said that it answered all the purposes of the officinal Jalap. "It produces copious liquid discharges, with no griping." It was employed by the Cherokees as an anthelmintic. A few drops poured into the ear are said to restore the power of hearing. It has also been found to afford speedy relief in incontinence of urine.

Polygala, polygama.-U.S. Disp., 558.

Polygonum, punclatum (P. hydropiperoides of some Bot. Water pepper.)_Eb. Mat. Med. I., 441 ; U. S. Disp., 559 ; Ed. \& Vav., Mat. Med., 125; Le. Mat. Med. II., 193; Ogier in S. Jour. Med. Pharm., 1846; Me. \& de L. Dict., de Mat. Med.t. V., 433 ; see P. hydropiper, English physician, p. 21. In amenorrhœa, Eberlie asserted that he employed it in 20 cases, and was never more successful-late experiments have confirmed this assertion.

P. aviculare, (Knot grass.)-Me. \& de L. Dict., de Mat. Med., t. V. 440 ; U. S. Disp., 558 ; Lind. Nat. Syst., 211 ; emetic and purgative - some say powerfully so. This plant has at one time received considerable attention. It was said to be very useful in Hernia, and in arresting the vomiting of blood and hemorrhage. It was regarded as an excellent vulnerary in moderating fluxes, diarrhœa, and dysentery. It should be experimented with; see the Dict. de Mat. Med.

Portulacca oleracea, (Purslane.)-Me. \& de L. Dict., de Mat. 
Mod. t. V., 459. Antiscorbutic, diuretic, and anthelmintic. The Dispensatory does not give it the attention that it received in various parts of Lurope. It is vaunted as an antidote for polsoning from cantharides. See Dict., de Mat. Med., loc. cit.

Prunella vulgaris, (Heal all.) Med. Dict. Parr. art., BrunelJa, Le. II, 245 ; U.S. Disp., 1291 ; Ed. \& Vav. Mat. Med. 276 ; Me. \& de L. Dict., de Mat. Med., t. V., 520. This plant, though possessing stimulant powers, has nevertheless fallen into disreplite. It was used as an astringent in affections of the throat.

Psoralea erlandulosa.-Me. du de. L. Diet. de Mat. Med., t. V.,525. "'The P'. glandulosa has been regarded as a powerful vermituge and good stomachic, the decoction arrests the flow of blood, and an infission of the root produces vomiting." Dict. de Mat. Ned.

Pterocaulon pycnostachyum, (Black root.)-Ell. Bot. Med., note II., 321. Used in domestic practice in St. John's, at an alterative, the black ront of the negroes.

Quercus virens.-U. S. Disp., 5s1; Eb. Mat. Med I., 376.

Q. fulcut ', (Spanish oak.)-Chap. Therap. II., 493; U. S. Disp., 581 ; Bart. Essay to Mat. Med.; Alibert Nouv. Elemen.

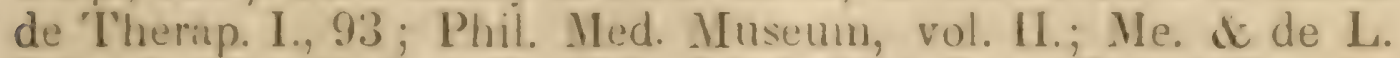
Dict. de Mat. Med., t. V., 580 ; Lind. Nat. Syst. Bot., 170. An astringent wash for gangrene, a decoction administered with great success in dysentery, uterine and pulmonary hemorrhage, and in intermittent fever. In domestic practice, where an easily obtained and efificient astringent is required, it is of no little valne; used to considerable extent on the plantations.

Q. Linctorin, (Black Oak.)-Am. Mled. Record. III., 363; Bart. Essay to Mat. Med. II.; Ediub. Med. Journ. No. T2; Pe. Mat. Med. II., 191; U. S. Disp., 581; Michaux N. Am. Sylvia, 1., 91 ; Jourual de Pharm., et de Chim. V., 251; Royle Mat. Med., 5.59 ; Ball. de Gar., 3.16 ; Me. \& de L. Dict, de Mat. Med. t. V., 590. In addition to the qualities possessed by the $\mathrm{Q}$. falcat?, this is purgative. They have both been efficacions in leucorrhcea, anemorrhoea, chronic hysteria, and diarrliœa, rheumatism, pulmonary consumption, tabes mesenterica, cynanche tonsillaris, and asthma. Mr. Lizars has used it "with wonderful success" in the cure of reducible hemia. Eberle Inc. cit.

Q. Alba.-U. S. Disp., 55:2; Royle Mat. Med., 659. Decoction as a bath for children in marasmus, scrofula, de.

Rhus copallinum, (Sumach.)-Ell. B3ot, 302; 1.d. \& Vav., Mat. Med., 136. A wash applied to ring worms; root used by Chipeway Indians, as an anti-venereal. 'The excrescences on leaves powdered, and made into an ointment for application in hemorrhoids.

R. radicans, (Poison Jovi.) - Eb. Mat. Med. II., 117 ; Eill. Bot. 363: Bell's Pract. Dict., 453; Ann. de Chim. XXXV,, 106 ; U. 
S. Disp., 717 ; Ed. \& Vav., Mat. Med., 345 ; Pe. Mat. Med. II., 603 ; Alibert Elemens. de 'Therap. t. I., 452; Big. Am. Med. Bot. III., 20; Du Fresnoi, quoted in Ann. of Ned., IV., 1 S2 \& V., 483; Med. and Phys., Journ. I., 30S, VI., 273, \& X., 486; Trous. et Pid. 'Traité de Therap. t. I., 524; Journ. de Chim. Med. Juin., 1825; Duncan's Disp., 294, Cit. in Big.; Me. \& de L. Dict, de Mat. Med. t. VI., 78. It produces in those who come into its vicinity, an erysipelatous inflammation. The juice, which exudes on plucking the stem, makes a good indelible ink. The bruised leaves of the collinsonia canadensis, (which also grows in S. C.,) are employed for the eruptions caused hy the emanations from the poisonous sumacs. A French writer testifies to the efficacy of this plant, in homoepathic doses, in all the diseases of the skin. See the Dict. de Mat. Med.

R. venenatu.-Me. \& de L, Dict., de Mat. Med., t. VI., 82; Dudley Phil. Trans, Abr. VI., 507; Sherard ditto, 508 ; Kalm's Travels, I., 77 ; Marshall Arbusts, 130 ; Cutler Am. Acad. 427; Big. Am. Med. Bot. I., 36 ; Bart. Coll. 24 ; Thacher's Disp., 321 ; Cit. in Big., see R. Vernix; Nouv. Journ. de Med. XV., 43. It causes the body of one who comes in contact with it, to swell enormonsly, some are even affected by breathing the atmosphere around it.

R. toxicodendron, (Poison Ash.)-Trous. et. Pid., Traité de Therap. t. I., 524; Bell's Pract. Dict., 453; Eb. Mat. Med. II, 116; Pe Mat. Med. II., 603 ; Ed. \& Vav. Mat. Med., 345 ; U. S. Disp., 718; Ball. \& Gar., 241 ; Royle Mat. Med. 331; Bergii Mat. Med. I., 248; Me. et de L. Dict. de Mat. Med. t. VI., 78; Orfila Toxicologie gén. 1, 45; Ann. de Chim. XXXV., 186 ; An. Journ. de Med. LXXX., 136. Stimulant and narcotic in paralysis and herpes; of the former disease, 17 cases are reported by one physician to have been successfully treated by it. 'The verbena urticifolia, also growing in St. John's, is an antidote for poisoning by this plant.

Rubus villosus, (High black berry.)-Pe. Mat. Med. II., 453; Ed. \& Vav., Mat. Med., 134 ; Eb. Mat. Med. I., 386 ; U. S. Disp. 603-4; Royle Mat. Med., 374 ; Ball. \& Gar., M. Med., 267; Big. Am. Med. Bot. II., 160 ; Chap. Therap. II , 474 ; Thacher's Disp., 341 ; Lind. Nat. Sys., 144 ; Bart. II., 157. Used in cholera infantum. The "English physician," (see Magnolia glauca) says of one of the genus rubus, "either the decoction or powder of the root being taken, is gond to break or drive forth gravel, and the stone in the reins and kidneys." "The berries of the flowers are a powerful remedy against the poison of the most venomous serpents!!". p. 48.

R. trivialis, (Creeping black herry.) - Watson's Pract. Physic. 820 ; Pe. Mat. Med. II., 543 ; U. S. Disp., 603 ; Royle Mat. Med. 375 ; Chap. on diseases of Abdom. and Thorac. Viscera, 279 ; 
Brit. \& For. Med. Rev., 31 Jan., 1515; Ball. \& Gar., Mat. Med, 268. I decoction of root, said to be a safe, sure, and speedy cure lior dysemery; remedy dermed from the Oneida Indians.

Ruellia strepens. Lind. Nat. Syst. But., 255; Ainslie II., 153.

Rirmex acetosella, (Field sorrel) - Pe. Mat. Med., II, 27.3; U. S. Mispen. 6(15: Ld. A Vav. Mat. Med. 5:36; Bergii Mat. Med. I., 300. "It may be administered with erreat advantage as an arlicie of dien un seorhuric eomplanints." Disp. loce cit.

R. brilanica. U. S. Disp., 606.

R. crispes, (Dock.)-Eil. Bot., 414; Matson's Veg. Pract.299; U. S. Disp, (imb. Ruot lormised with milli an extermal application for scaties, it mules a tonic and astringent, wull a laxative property, somewhit resembling rhubarb in its operation.

A'bhatia (chironin Lin) ansularis. (Am. centaury.)-Ell. Bot. I., 355: Chap. 'Therap., 435 and II., 117 ; U. S. Disp, 611 ; Pe. Mat. Med. 11, 311: Royle Mat. Med. 175; Fb. Mat. Med. 1, 307; see chironia. Biy. Am. Med. Bot. III., 147: Bant. Med. Bot. 1. 2.55; Ed. \& Vav. Mat. Med., 176; B. S. Bart. Coll. 10 Mat. Med. 1, 15; Lind. Nat. Syst., 29\%. "Pure bitter with tonic and stomachic." Used in domestic practice in intermittent fever. Fiverle silys this is one of the most useful of our indigenous bitters. This and the lirindendron tulipefera, might he of great service to those who cannot employ more expensive articles. With the excoption of a plant, which I have urver seen flowering: and themelore cammot ascertain the name, the S. angularis possesses tire most intensely bitter taste I ever noticed among our native herbs. The one alluded to, bears a general resemblance to the violaceate, and grows in rich shaded soils.

Sustlarin sugrllifulin, (Arrow-head.)-Me. et de L. Dict. de Mat. Med. t. VI, 15:3; Jouru. Comp. des Sci. Med. XIX., 143. Said to have a fecula like arrow-root, (Maranta arundinacea.;

Naler nierr, (IVillow.) -Bell's Pract. Dict., 103; U. S. Disp. 622. See Work of the ynunere Michanx. Ball. \& Gar. Mat. Med., 337 ; MI: et de L. Dict. de Mat. Med. t. VI., 1S4. The willow yirlds us one of our best substitutes for Peruvian Bark. The S. il ba seems in be lield in more estimation than the S. ni. gra. The: former though introduced is common, and may possibly be inchuded amones severil douhful specimens which I have. This s. nigra is purgative and febrifuge in the form of decoction.

Silria Lyruta, (Cancer weed.)-Eill. Bot. 1, 31. "The Iresh radical leares of the plant, when bruised, and appliced to warts, generally destroy them; comtimue the applicition for a day or two, and renew it every twelve homs." So also the leaves of the Hieracium gronovii.

\$. officinalis. Fd. \& Vav. Mat. Med., 26s; Me. et. de L. Dict. de Mat. Med. t. VI., 191, \&c. "Euglish physician by Nick 3* 
Culpepper. Student in physic and astrology," p. 295. "Jupiter claims this and bids me tell you it is good for the liver and to breed blood" An aphrodisiac. "Helpeth conception, and hinders miscarriage."

Sambucus canadensis, (Elder.)-Ie. Mat. Med. 11, 325 ; U. S. Disp., 625 ; Dray. View. S. C. 66 ; Bell's Pract. Dict. 404; (art. S. nigra) Royle Mat. Med. 423; Cull. Mat. Med. 11, 534; Me. et de L. Dict. de Mat. Med. t. VI., 196 ; Lind. Nat. Syst. Bot., 248. Leaves fœtid, emetic, and a drastic puruative." Lind. loc. cit. sup. Flowers are excitant and sudorific, used externally as a discutient; the berries are diaphoretic and aperient, employed as a remedy in rhenmatic gouts and syphilitic affections; the inner bark is a hydragogue carthartic and emetic, acting in dropsy, and as an alterative in various chronic diseases. The leaf-buds are also said to act as a violent purgative. Op. cit.

Samolus valerandi, (Brook weed.)-Me. \& de L. Dict. de Mat. Med. t. VI., 201; Journal Gen'l. de Med. LII., 413. Lemery says it is anti-scorbutic, aperient and vuluerary.

Sanguinaria canadensis, (Puccoon, blood-ront.)-Drayton's View S. C. 72 ; Bell's Pract. Dict., 404 ; Eb. Mat. Med., 95; Lind. Nit. Syst Bot., 8; U. S. Disp., 627 ; Royle Mat. Med. 273; Pe. Mat. Med. II., 722; Am. Lyc. Nat. Hist. N. York, II, 250; New-York Med. Phys. Journ. 1, No. 2; London Med. Chirur. Trans. Vol. 1, Barton's Med. Bot., 1, 30 ; Ans. Journ. Med. Sci. N. S. 11,506 ; Journ. Phil. Coll. Pharm. III., 95; Ball. \& Gar. M. Med., 208; Big. Am. Med. Bot. 1,75 ; Schoepf. Mat. Med. 85; Trans. Lond. Med. Soc. 1, 179 ; Barton's Coll. \& Mat. Med. 28; Cutler Mem. Am. Acad. 1, 455 ; Thacher's Disp. 331; Me. $\&$ de L. Dict. de Mat. Med. t. VI., 208; Bull. des Sci. Med. Fer. VI., 71; Edinb. Med. Journ. V1I., 217; Shec. Fl. Carol. 153. Emetic and purgative in large doses; stimulant, diaphoretic and expectorant in small. Very efficacious in jaundice. Extensively applied in domestic practice in St. John's, Berkley. It is an acrid narcotic, causing vomiting, given in catarrh, typhoid, pneumonia, croup, rheumatism, \&c. The Indians used the juice, which exudes from the root, as a red pigment. 'The stain applied to the unbroken skin is not indelible. Merat says it is serviceable in gonorrhœa, the bite of serpents, and in bilious fever; he affirms that it has been employed with marked success in arresting the progress of phthisis and inflammatory rheumatism. and by Dr. Smith of Hanover, in destroying mucous polypi in the nose. Eberle in his work on the Diseases of Children, p. 97, says that the powdered root is an excellent escarotic, in ulceration of the umbilicus, \&c. This plant is abundant around us, and should receive greater atteniion.

Sarracenia, (Side saddle flower.)-Me. \& de L. Dict. de Mat. 
Med. 1. VI., 226. Where Dr. MclBide's diss. in the 12th vol. of Trans. Lin. Soc. is referred to.

Suururus cermuus, (Lizard's tail.)- Eill. Bot. 43:3. The fresh root, applied in the form of a poultice, as an emolient and discutient to inflamed surfaces.

Scirpus palustris, (Marsh club rush.) - Me. ot de 1. Mict. de Mat. Med. t VI., 262. Said to he used in the manulacture of bonnets, medicinal also. See op. cit.

Sculellaria integrifolia. U. S. Disp., 1294.

S. lateriflora, (Mad.dog scull cap.) - U. S. Disp., 1291, App.; Watson's Pract. Physic, 3S6; Me. et de I. Mict. de Mat. Med. t. VI.. 27.1; Bull. de la Fincultié VII., 191; An. 1S20, where Spalding's report, concerring its anti-hydrophobic virnes, is referred to. Youatt spotie in very favorable terms of this remedy, see Watson loc. cit. It enjoyed the reputation of being the only one for this disease.

Sestmmm indicum, (Bene.)-Coxe Am. Disp. art. sesamum orientale. Me. et de L. Dict. de Mat. Med. t. VI., 331. 'The sesame of the Auabasis, mentioned by 1)iuscorides, Thenplirastus, and whers. Some prefer the oil of the seeds to the oleuns ricini. In India it is reoarded as enmenagorne, and a provocative of abortion. ('oxe says it was very ustulu in a dysentery, which prevailed in 1\$03. See the Dict. de Mat. Med.

Silene virginica. [T. S. Disn. 1296, Ap. ; Me. et de L. Dict. de Nat. Med.t. VI., 312; Je Caudolle's Essay, 94; Lindley Nat. Syst. Bot., 125. Decoctinn of root acts as an anthelmintic. Its vermifuge virtues should be examined into.

Sisymbrium amphibinm, (Water radish.)-Me. et DeI. Dict. de Mat. Med., t. VI., 36.5. Recommended for taenia by Didelot, and, in the old worlis, as an antiscorbutic. Merat says the ront and young leaves are eatable in the spring. This plant might also be noticed more particularly.

Smilax-pseudo-china, (Chima hriar.)-Eill. Bot., II., 700; U. 8. Disp., 634; Per. Mat. Med., 133; DeCandulle Podron., I., 351. Considerable use made of this plant, in domestic practice, in St. John's; basis of diet drinlis; one of our best suhstitutes for sarsaparilla. Dr. Frost ("Elements of Mat. Mrd.") considers the $\mathrm{S}$. herbacea, also, valuable as an alterative. Iatter grows in rich shaded soils.

S. tommnoirles.-Mer. et DeI. Dict. de Mat. Med., t. VI., 384. The root, says Merat, is also used in decoction, to purify the blood. Loc. cit.

Solumum nigrum, (Deadly night sharle.)-Trous. et Pid. Traite de Therap. et de Mat. Med., t. I., 206; Eb. Mat. Med., II., 39; U. S. Disp., 304; Fd. \& Vav. Mat. Med., 343 ; Royle Mat. Med., 195; Pe. Mat. Med., II., 326 ; Le. Mat. Med., II., 272; Mer. et DeL. Dict. de Mat, Med., t. VI., 417: Journ. de Chim. 
Med., III, 541 and 422; Nouv. Journ. de Med., X., 67; Alibert Nouv. Elemens. de Therap. t. I., 417. Eberle says this plant is "by fir ton much neglected." The berries are an active narcotic poison. It is used with great advantage in chronic ulcers of a cancerous nature, in scorbutic, herpetic and syphilitic eruptions. The Dict. de Mat. Med. notices its effects in visceral obstructions and in catarrh of the bladder, (le catarrhe vésical.)

S. caroliniense, (Horse nettle.)-Me. et DeL. Dict. de Mat. Med., t. VI., 410. Recommended by Valentin, in tetanus, (non traumatique.) They did not have it in sufficient quantities to repeat the experiment; with us, it is abundant. It possesses some reputation among the negroes as an aphrodisiac.

Solidugo sempervirens.-Mer, et DeL. Dict. de Mat. Med., t. VI., 436.

Sonchus oleraceus.-Mer. et DeL. Dict. de Mat. Med., t. VI., 439. Emollient.

Spergula arvensis.-Mer. et DeL. Dict. de Mat. Med., t. VI., 497. "Cows which feed on it give milk in larger quantities and of a richer quality." Loc. cit.

Spigelia marilandica, (Pink root.)-Eb. Mat. Med., 214; Ell. Bot., 237 ; Fr. Elems., 197; L.e. Nat. Med., II., 377 ; Biğ. Am. Med. Bot., I., 142; Home Chim. Exper., 420 ; Murray App. Med., I, 548; Royle Mat. Med., 469; Thompson Inaug̣. Diss. Feneulla Jouru. de Pharm., IX., 197; Griff. Phil. Jour. Pharm., App. 1833 ; cit. in Big.; Chalmers on Weather and Dis. of So. Carolina, I., 67 ; Garden's Essay Phys. and Liter., III., 145, and Lining, vol. T., 386 ; Ess. and Obs., Phys. and Lit.; Bell's Pract. Dict., 433 ; Ed. \& Vav. Mat. Med., 595 ; Pe. Mat. Med., II., 344 ; U. S. Disp., 680 ; Ball. \& Gar. Mat. Med., 334 ; Bergii Mat. Med., t. I., 96 ; Me. et DeL. Dict. de Mat. Med., t. VI., 502; Coxe Am. Disp., 128 and 55̌; Bull. des Sc. Med. de Ferus., XI, 301 ; Lind. Nat. Syst. Bot., 299 ; Bart. Am. Med. Bot., II., 80. Abundant in rich spots, margin of roads, \&c.; well known as an anthe!mintic, cathartic and narcotic. Of vary great use on the plantations in St. John's, as a vermifuge.

Styllingia sylvatica, (Queen's delight.)-U. S. Disp., 6S7; Frost, in So. Journ. Med. and Pharm., Oct., 1846. A valuable ingredient in the composition of diet drinks. Adds to the efficacy of sarsaparilla. Used in St. John's, in the treatment of syphilis, and as an alterative in scrofula and cutaneous diseases generally. A very acrid milk exudes in great abundance from the bruised surface. Those living in the country, where it is very abundant, should ascertain the virtues of this plant with greater certainty. It is worthy of an examination.

S. sebifera.-Me. et. DeL. Dict. de Mat. Med., t. II., 476; see Croton sebif. of Mich. An ointment made from this is applied in nocturnal fevers. The Chinese, according to Thunberg, em- 
ploy the concreted oil extracted from the plant in manufacturing candles.

Taruxacum densleonis, (see Leontodon of some Bot.; DandeLion.)-Watson's Pract. Physic., 39 ; Bell's Pract. Dict., 445; Royle Mat. Med., 453; Pe. Mat. Med., II., 401 ; Ed. \& Vav. M. Med., 1s4; C. S. Disp., 706; Wilson Philip Dis. of Abdom. Viscera; Le. Mat. Med, I., 396; Brande Dict. Mat. Med. and Pharm., 63:; Woodv. Med. Bot., 39, t. 16; DeCandolle Podro., VII., 45; Ball. \& Gar., 319; Bergii Mat. Med., II., 687; Me. et DeL. Dict. de Mat. Med., t. IV., s7; English Physician, by N. Culpepper, Student in Physic and Astrology, p. 109. "Jaundice and hypochondriacal affections." A perient and diuretic in hepatitis and dropsy. See Woodv. Med. Bot. It is spoken highly of in chronic affections of the liver, and used to some extent in the composition of diet drinks. Eberle reconmends it in chronic cases of infantile jaundice, ("Diseases of Children.") The young branches and shoots may be eaten as a salad.

Tillandsia usneoides, (Common moss.) -Mer. et DeL. Dict. de Mat. Med., t. VI., 743; Journ. de Pharmacien, III., 185. Stomachic, purgative, and even diuretic; employed in hemorrhoids. Loc. cit. We see no notice of it in the Am. Dispensatories.

Trifolium repens.-EIl. Bot., II.. 201.

$T$. reflcxum.-Affects very sensibly the salivary glands.

Trillium sessile-_Lind. Nat. Syst. Bot., 348. "Roots generally violently emetic."

Triplerella ccerulea, (Blue tripterella.) - Lind. Nat. Syst. Bot., 331 ; Nuttall in Act., Phila., 7, 23.

Typha latifolia, (Cat tail.) - Me. et DeI. Dict. de Mat. Med., t. VI., 795; Jouru. de Chim. Med., IV., 179; Journ. de Pharm., XII., 564. This plant has received a very extended notice in the work cited. The root is eaten as a salad; a jelly is also extracted from it. Aublet assures us it is good in gonorrhoca and chronic dysentery. The bark has been employed in the fabrication of hats, and with cotton, in making gloves, and some have recommended it in manufacturing china paper; see the Dict. de Mat. Med. loc. cit. We would call attention to it.

Ulmus americuna.-Mer. et DeL. Dict. de Mat. Med., t. VI., 799 ; Phil. Med. Museun, II.; Coxe Am. Disp., 611. It is probable he refers to the Clmus fulva, (Slippery Elm,) which grows in the upper part of South-Carolina. I have seen it in Fairfield District.

Vaccinium arboreum, (Farcle berry.)-Ell, Bot., I., 496. Bark of ront very astringent; used in the form of decoction, for chronic dysentery and diarrhœa. Loc. cit.

Terbascam thipsus, (Mıllein.)-Pe. Mat. Med., II., 295; U. S. Disp., 735 ; Watson's Pract. Physs., 202; Royle Mat. Med., 493 ; Le. Mat. Med., II., 416 ; Journ. de Chim. Med., t. II., 223; 
Home. Clin. Exp. and Hist.; Bergii Mat. Med., I., 118; Me. et DeL. Dict. de Mat. Med., t. VI., 864 ; Bull. des Sc. Med. de Ferus., XVI., 341. Leaves demulcent and anodyne emollient; infusion administered on the continent of Europe, in catarrhs, and decoction in diarrhœa, Among the poorer classes it is much employed as a dressing for sores. Merat states that it is efficacious in colicks, ardor urinæ, and, a watery distillation of the flowers, in erysipelas.

V. blattaria.-Me et DeL. Dict. de Mat. Med., t. VI., 863.

Verbena urticifolia, (Nettle-leaf vervain.)-U. S. Disp., 1304. An antidote for poisoning by the rhus toxicodendron.

Vernonia angustifoliu. - Root used by negroes as a remedy for the bite of serpents.

Vicia sativa.-Me. et DeL. Dict. de Mat. Med., t. VI., $S 93$.

Viscum verticillatum, (Misletoe.)-Le. Mat. Med., II., 456 ; Me. et DeL. Dict. de Mat. Med., t. VI., S66; Journ. de Med., LXX., 529 ; Lind. Nat. Syst. Bot., 50; Eberle "Diseases of Children," p. 522. In infantile epilepsy, \&c.

Violı cucullata -Le. Mat. Med., I., 223. A decoction given to children in eruptive diseases. Loc. cit.

V.tricolor.-Le. Mat. Med., II., 453; U. S. Disp., 743 ; Trous. et Pid. Traite de Therap. et de M. Med., t. II., 15; U. S. Dis., 743.

V. palmatta.-El1. Bot., 300. Very mucilaginous; employed by negroes in making soup; commonly called wild okra. Bruised leaves used as an emolient application.

Xanthium strumarium, (Burr, Burdock.)-Me. et DeL. Dict: de Mat. Med., t. VI., 970; Diascoride's Lib., IV., 133. It has been administered in scrofula; properties not accurately ascertained.

FERN :

Osmunda regalis.-Lindley's Nat. Syst. Bot., 400. "Has been employed successfully, in doses of three drachms, in the rickets." Op. cit. 


\section{A T A LOG U E}

Of Phanogamons Plants and Ferns, native, naturalized, and exotic; collected in the Parish of St. John's, Berkley, Someh-C'arnlina; Lut. 81 10; Long. 33, 15. Lainds lying between the waters of ('onjer and Santee Rirers. forty miles from the ncean; trenty feet abore lide level, embrucing a grouth of Oak, Hickory, Suamp and River T'rees.

Plants markei thus (\$) are not deseribel, uniter the names griven in this ('atalngue in Flliott's siketch. For uther references see May Number, in intruduction to first part uf Catalogue.

Acalypha virginica, Linn. in wet corn fields.

Acer rubrum, swamps Linn. and rich soils. saccharinum, $\mathbf{M} \bar{x}$.

Acerates longifolia, Ell. Sk. July. along ditches.

+ Achillea millefulia, Linn. rich cultivated soils.

+ Achyranthes repens, Ell. common on mar. gin of roads.

+Acorus calamus, Linn. in morasses-roots immersed.

Achnida,

Acinella, (see Spilan-

$$
\begin{aligned}
& \text { repens, } \\
& \text { damp soils. }
\end{aligned}
$$

†Aesculus pavia, (rich Linn. oak land.)

+ Agave virginica, in Linn.

Wasamasa-bear Black Oak.

+ Ágrimonia eupatoria, Linn. drv oak lands. $\zeta$ parviflora, S. \& Gy. snaveoleus Elll. sk. side of roads.

Agrostis (juncea seo $\mathbf{M x}$. vilfa.) indica, past'es. irichupuiles,

Aira obtusata, clandestina, Fid Gry

\begin{tabular}{|l|} 
July. \\
Feb. \\
Mar. \\
July. \\
July. \\
My. O. \\
Ap.
\end{tabular}

Alium striatum, bor-: Pursh. der of roads. mutabile,* $\mathbf{M x}$ cepa, (Ex.) In. sativa, (Ex.) porrum, (Ex.) fragrans, (Ex)

+Alnus serrulata, Ait. damp pine land. bays.

Alopecurus genicula-Linn. tus, in rice fields.

Amaranthus hybridus, Linn. spinosus, Linn. in old settlements. boidus,

rich cultivated soils. Linn. Julv. Maj. May. July.

July.

July.

Ap.

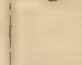

July -

July.

A uig. + Amaryllis atamasco, EI. S. Li.|Mày. wet swampy land.

Amelan- canad-

May.

$\left\{\begin{array}{c}\text { chier } \\ \text { Aronia }\end{array}\left\{\begin{array}{c}\text { ensis, } \\ \text { va. bot- }\end{array}\right.\right.$

Ell. Sk. ryassium arbutifolia.

† Ambrosia, (artemisi- T. \& Gy. Aug. aefolia $\mathrm{v}$. $\{3$

panicu- Ell. Sk.

$\left\{\begin{array}{l}\text { Aug. } \\ \text { July. }\end{array}\right.$

July

pastures.

Ammania pumilis, Mich. wet soils.

AmmiseeDiscopleura,

Amorpha futicusa, Linn. border of roads.

S herbacea, W.T\& G July. \{ pubescens Ell. Sk.

Ampelopsis quin- Mich. July. pallens, pine land. mollis,

+ Aletris aurea,

MI. Cat Sept. Ell. May.

Sept.
May. pastures. quefolia,

(Cissus hederacea, Ell. s'k. border of roads and along fences.

Amphicarpa monoica, Ell. Sk. A A ug 


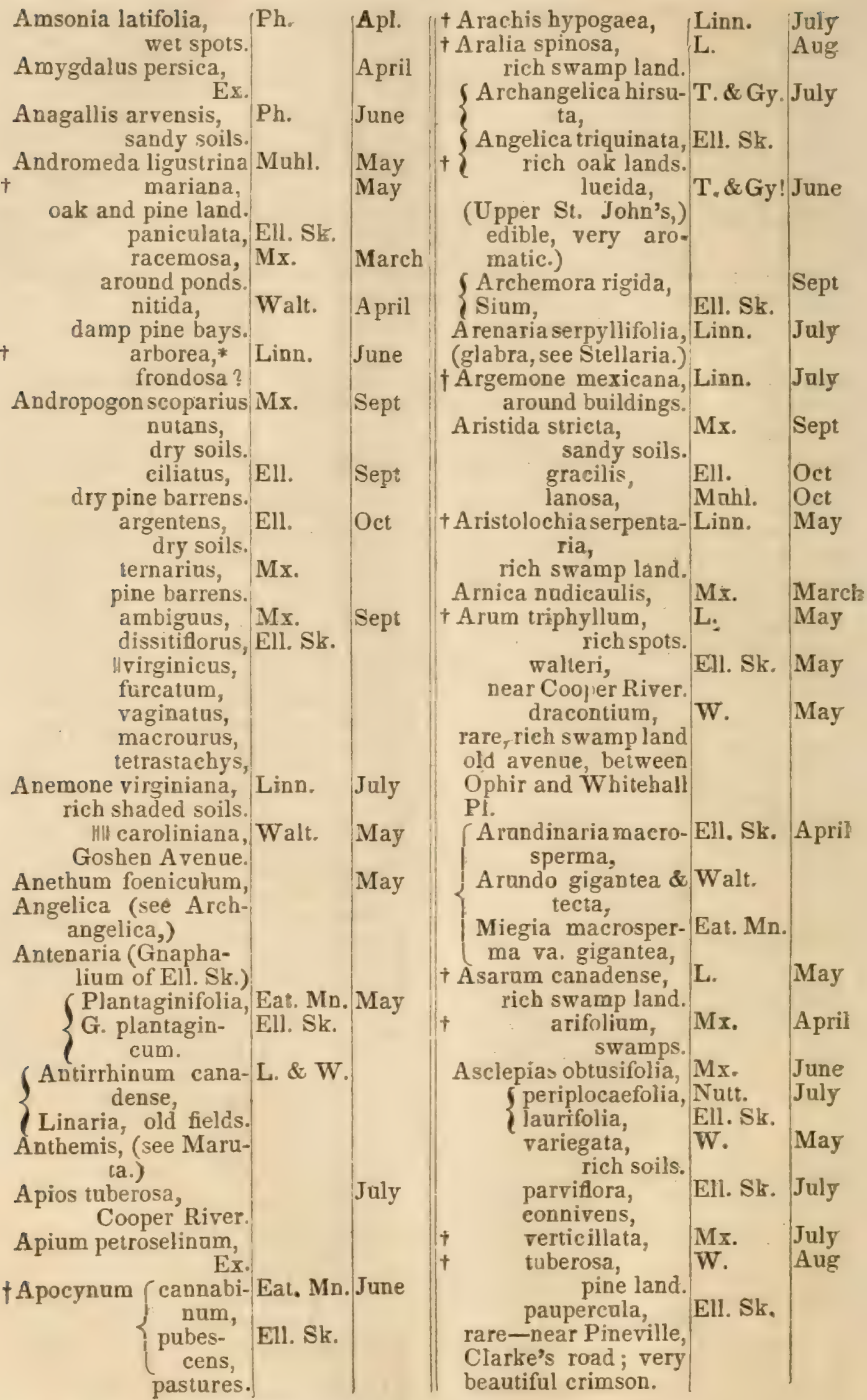

II Ell. Sk. a synonyme of Linn. under a dissitiflorus.

III Ellott says. "This beautiful and fragrant plant has probably escaped the notice of all our Botanists, except Walter, its habitation in this country is very limited." Vol. II., 53. I found it in the Avenue, at Goshen Plantation. 


\begin{tabular}{|c|c|c|}
\hline angustifolia, & & June \\
\hline $\begin{array}{c}\text { amplexicaulis, } \\
\text { sandy soils. }\end{array}$ & $\mathrm{Mx}$ & May \\
\hline Ascyrum crux-andrae & W & July \\
\hline \{ hrpericoides, & Ell Sk & \\
\hline $\begin{array}{l}\text { Istans, } \\
\text { Ury pine lands. }\end{array}$ & T \& Gry & \\
\hline amplexicaule? & $\mathbf{M a}$ & Aug \\
\hline Asparagus officinalis, & Linn & May \\
\hline $\begin{array}{l}\text { gruws wid on banks } \\
\text { of Cooper river. }\end{array}$ & & \\
\hline $\begin{array}{c}\text { Aster, (see Sericocar- } \\
\text { pus.) }\end{array}$ & & \\
\hline concolor, & Linn & Aug \\
\hline f patens, & T\&Gry & \\
\hline undulatus, & Ell $\leqslant$ i L & ()et \\
\hline undulatus, & $T \& G$ & \\
\hline diversifolius. & Ell Sk M & Oct \\
\hline $\begin{array}{l}\text { coruinomus, } \\
\text { oak lands. }\end{array}$ & & \\
\hline squarrosus, & & Nov \\
\hline carolinianus, & $\mathrm{Wr}$ & Oct \\
\hline $\begin{array}{l}\text { on Santee canal, and } \\
\text { near Multerry Cas- }\end{array}$ & & \\
\hline & W. & Nor \\
\hline $\begin{array}{l}\text { dry soils. } \\
\text { multiflorus, }\end{array}$ & A it & Sept \\
\hline $\begin{array}{l}\text { pine land. } \\
\text { versicolor, }\end{array}$ & IV & Sept \\
\hline $\begin{array}{l}\text { rich wet soils. } \\
\text { scaber? }\end{array}$ & Ell & \\
\hline $\begin{array}{l}\text { 5Baldwinii, } \\
\text { paniculatus, }\end{array}$ & & \\
\hline & $\operatorname{Lin} n$ & Sept \\
\hline $\begin{array}{l}5 \text { miser, } \\
\text { Aulaxanthus ciliatus, }\end{array}$ & Ell & Sept \\
\hline $\begin{array}{c}\text { pine barrens. } \\
\text { rufus, } \\
\text { damo soils }\end{array}$ & Ell & Aug \\
\hline Azalea nudidora, & Linn & May \\
\hline $\begin{array}{l}\text { rich shaded spots. } \\
\text { viscosa, }\end{array}$ & WV & June \\
\hline Baccharis balimifolia & L & Uct \\
\hline $\begin{array}{l}\text { old fields. } \\
\text { Baptisia tinctoria, }\end{array}$ & Ell & July \\
\hline oak lands. & & \\
\hline $\begin{array}{l}\text { alba, } \\
\text { near Santee river. }\end{array}$ & Ell & $\mathrm{Au}$ \\
\hline Berberis $\{$ caudensis & Nutt & \\
\hline volgaris, & Eat M & \\
\hline : ground. & & \\
\hline $\begin{array}{l}\text { Beta vulgaris, Ex. } \\
\text { Betula f rubra, }\end{array}$ & & \\
\hline $\begin{array}{l}\text { Inigra, } \\
\text { Santee river swamps. }\end{array}$ & T'SEISk & \\
\hline
\end{tabular}

\{ Berchemia volubilis|

Zizyphus, swamps-Ell Sk

Bedens, Mx chrysanthemoides,

frondosa,

bipinnata,

damp pastures.

( Bigelovia nudata, T \& Gry

Chrysocoma, Ell Sk

Bignonia radicans, L June cuitivated soils. capreolata,
crucigera,

Bletia aphylla, Nutt Aug

§Brachyelytrum erec-

Brassica rassa, Ex. oleracea, Ex.

Brassenia, (see Hydropeltis. peltata, Pursh July

submersed Santee ca-

Boltonia diffusa, Eall A ug asteroides,
Borkhansia, glastufolia,

(see Pyrrbypappus.)

Brickellia cordifolia,

Fr. Rev. C. Wallace, C. river.

Briza eragrostis, Me.

Bromus secalinus, *. W

Buchnera elongata, Fed Gry

Bunus sempervirens,

va. suffruticosa, Ex.

Bumelia lycioides, Ell

very rare-tree on Sarrazin Pl.

Cacalia atriplicifolia, Linn lanceolata, N Sept

rare -in Horsehead, near Pineville.

Cactus, (see Opuntia)

Callicarpa americana, Mx July

Callitriche $\int_{\text {rich soils. Wrna, Wune }}^{\text {verna }}$

damp soils generally $\left\{\begin{array}{c}\text { hetero- } \\ \text { phylla, }\end{array}\right.$ Ell Sk

Oct

June subinersed.

Calycanthus floridus, $\mathbf{M x}$

sweet scented shrub;

our most aromatic

plant. I have seen it growing wild in Fair-

field District. 


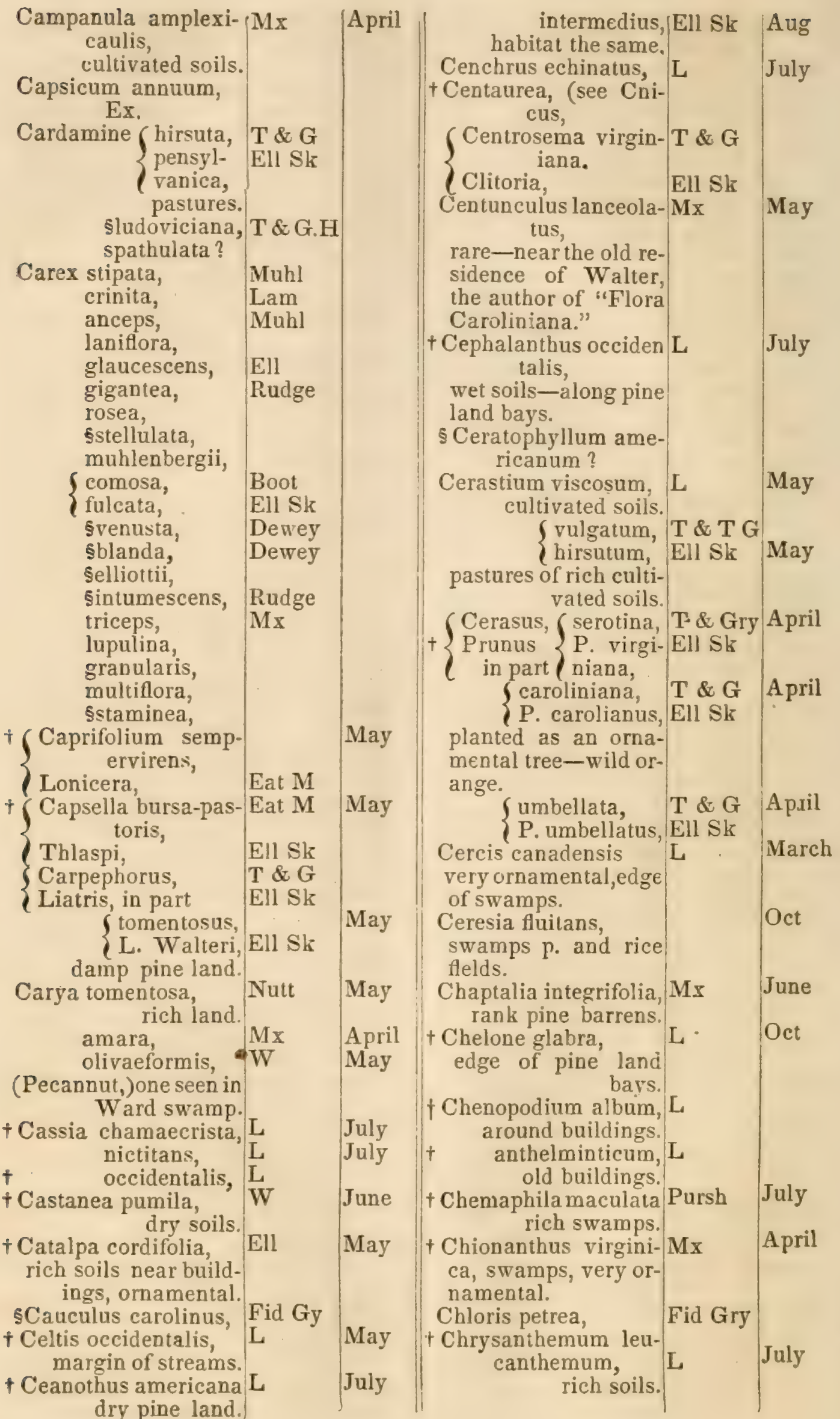


Chrysucuma, (seelBig- Mx elovia, Chrysogonum virgini- W anum,

Chrysopsis mariana, Nut pine land. gramiaitolia, Nutt pastures. trichophylla, Nutt gossepina, Mx dry pune land. argentea, Persoon pine land.

Chaerophilum procum-Fed Gry bens,

† Cicuta maculata, inunciated land.

Clayunia virginica,* L Cooper river.

Clematis cylindrica, T \& Gry edge of swamps.

Clethra tomentosa, L K damp pine land.

(Clitoria mariana, L Ell Sk Aug

$\{$ dry pine land,

Centrosema in part $\mathrm{T} \& \mathrm{G}$

Cnicus benedictus, $T \&$ G

$\{$ Centaurea, pastures Ell Sk

Cirsium maticum $T$ \& $G$

$\left\{\right.$ Cnicus $\left\{\begin{array}{c}\text { va! } \\ \text { C. glaber Ell Sk }\end{array}\right.$

Ell. Sk. horridulum $\mathrm{T} \& \mathrm{G}$ ? va. elliottii,

oak and pine land. repandum, virginianum,

Cochlearia armoracea Ex. Nat.

Collinsonia punctata, Ell rich soils. verticillata, Bald scabra, $\mathrm{Ph}$

Commelina virginica, $\mathrm{L}$ communis, Pursh pine land. erecta va. A L

Conoclinum coeles- $T$ \& $G$ Aug July

Eupatorium, Ell Sk

\} Convallaria biflora, Wr

f Polggonatum, Ell Sk rich swamp land.

S racenosa,

$\{$ smilacina race-Ell Sk $\{$ musa,

+ Cunvolrulus frandur- Mx atus,

oak and pine land. purpureus, $\mathbf{W r}$

Aug

July sagittifolius, | Mich

rice fields on Back

river.

dry pine and oak land aquaticus, Walter

damp pine land. battatus Ex.

Conyza(see Pluchea,)

Sambigua, Fd GDC

Coreopsis (dichotuma Mx gladiata, M \&ESk wet spots in pine land.

flanceulata va. T \& $G$

villosa.

Crassifolia, Ell Sk

auriculata, $\quad \mathrm{T} \& \mathrm{G}$

\{auriculata va. Ell Sk

diversifolia,

jelphinifolia, Lam

\{rerticillata, Ell Sk L July pine land. mitis, Mx angustifolia,

Sintegrifolia, T \& G \{semleri, Ell Sk

Saurea va. lesstophylla,

† Cornus florida, L rich oak land. stricta,

L'Herit May asperifolia,

Coronopus (see Lenebriera,

Corylus americana, Walt

generally rare-but abundant near Somerton plantation.

Cracichis multiflora, Ell very rich soils, rare.

Crataegus \{ aestivalis T \& G $\{$ elliptica, Ell Sk

very damp spots-

roots generally submersed.

parrifolia, crus galli, L

damp woods.

apiifolia, $\quad \mathbf{M x}$

coccinea va. T \& $\mathrm{G}$

$\{$ populifolia, pogulifulia, Ell sk pyrifolia,

richswampland. aborescens ? [EI] Jucida, Act Oct
Aug
July July

Sept Sept Aug A

Crotallaria sagittalis, $\mathbf{M x}$ dry pine land. ovalis,

Aug

Aug

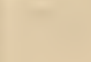


Cucurbita lagenaria, |W

nat. cultivated spots. pepo, Ex. W citrullus, Ex.W

Cumumis melo, Ex. W sativus Ex. W

+Cupressus disticha, L

roots submersed, inundated lann.

+Cascuta americana, I L wet soils.

Cyamus see Nelumbium.

Cymbidium pulchel-Sw

$\{$ lum,

va. graminifolia, Eat M

I have seen one with

white corolla near

Pinopolis.

Cynthia f virginica $T \& G$ ! May

Kregia amplexi-EH Sk

in part caule,

Cynodon dactylon, P

§Cynna arundinacea, Fid Gry

Cynoglossum amplex- $\mathbf{M x}$ icaule,

Cypens flavescens, L
virens, wet soils.

mariscoides, Ell.

flavicomus, $\mathbf{M x}$

§gateri,

strigosus,

smicrodontus,

bydra, fields. $\mathbf{M x}$

vegetus, Vaht. in ponds.

gracilis, Muhl.

speciosus, Pursh

enslenii, ditches.

margin of ponds Cyrilla racemiftora, $\mathrm{L}$

border of pine land

Cynara scolymus, bays.

Ex. Nat.

$\{$ Danthoniaglumosa, $\mathrm{Mx}$

A vena,

Datura stramonium, sround buildings.

Daucus carota,

pusilus,
Oct

Feb

Aug

Aug

A ug

Aug

June

Aug

June

Sept

Sept

Aug

July

Oct $\mathrm{Ph}$
May

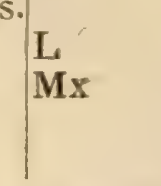

\section{Decumaria ( barbara, L\&T\&G|July * sarmen-Ell Sk \\ tosa,}

CDesmodium nudi- $T \& G$

florum, shaded soils. Ell Sk

laevigatum,

ciliare,

acuminatum,

\|llineatum! $\mathbf{M x}$

very rare.

f cavescens, $T \&$ G

scaberrinum, Ell Sk July fields.

S cuspidatum, T\& G Sep:

bracteosum, Ell Sk

\$pauciflorum, Fid Gry

paniculatum,

rhombifolium,

glabellum,

shady soils.

$\{$ marylandica, $T \& G$

obtusum, Ell Sk

strictum, pine land.

rotundifolium,

dry rich soils.

Dichondra carolinien- $\mathbf{M x}$ sis,

wet soils, generally submersed.

Dichromena leucoce- $\mathbf{M x}$ phala,

latifolia,

Digitaria sanguinalis, Scop

S serotina, $\mathbf{M x}$

\{villosa? Ell Sk

filiformus,

paspaloides, $\mathbf{M x}$ gglabra,

$\{$ Dilatris tinctoria, $\mathrm{Ph}$

Lachynanthes EH Sk

Sept

July

Aug

July

July

June

Aug

Diodia tetragona, Walt

pine land and damp

soils.

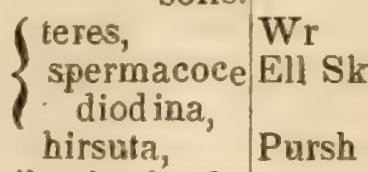

Aug

July

Aug:

Aug

Aug

dry soils pine lands.
† Diospyros virgiaiana, L damp soils.

S Diptopappus hinari- $T$ \& $\mathrm{G}$ folius,

Aster in part of

Ell Sk

" Only one Cascuta is described in Ell, Sk. There is a specimen collected in St. John's, which bears a strong resemblance to the $\mathbf{C}$, compacta! sent from elsewhere to Mr. H. W. Ravenel; it is not uncommon.

HII Elliott remarks : "If no error has crept into the description of Michaux, this plant has not re. cently been seen by any of our Botanists." It grows in the upper portion of the Parish, (II. W. $\mathbf{R}$ ?) and was also collected by the Rev. C. Wallace, near Cordesville. 


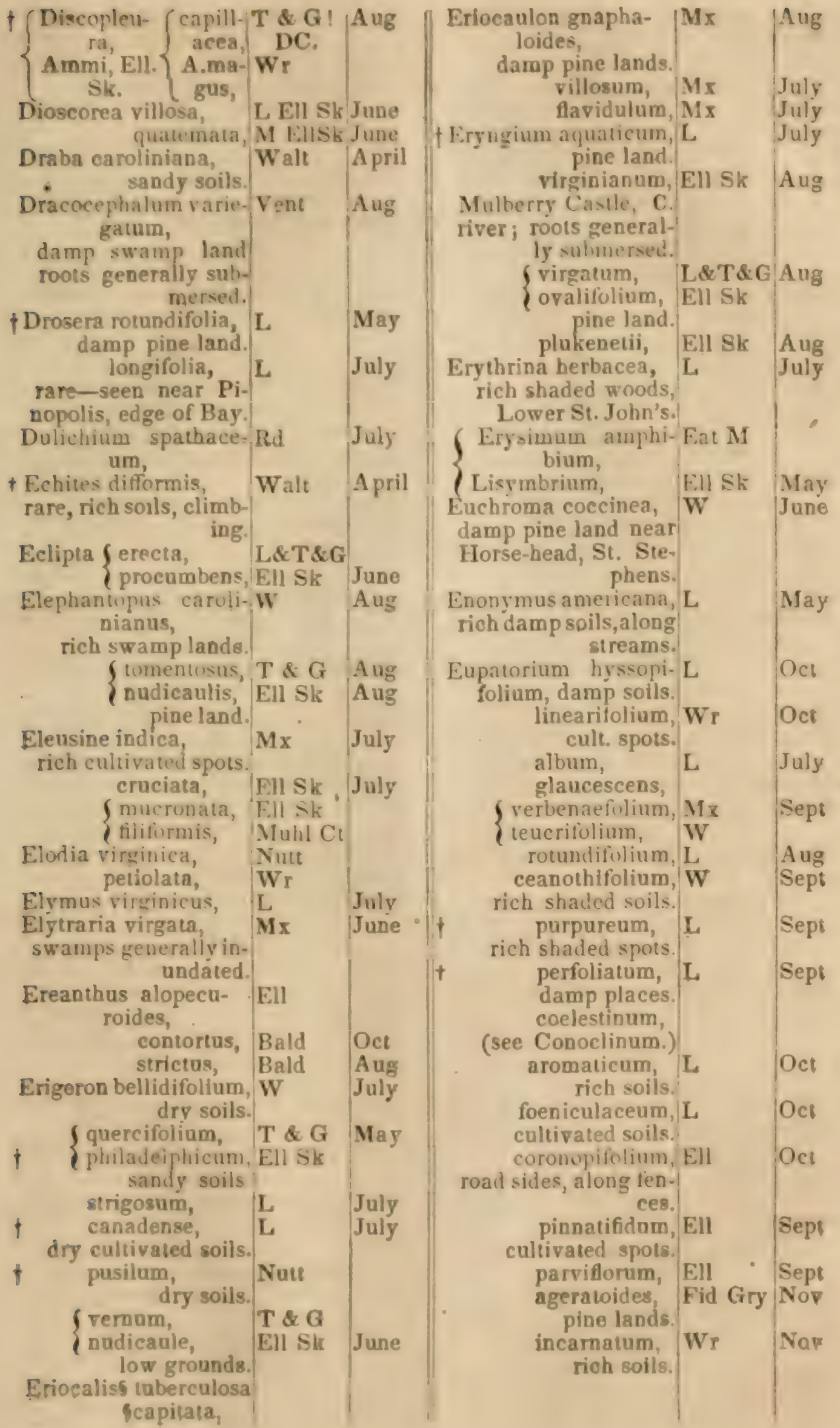




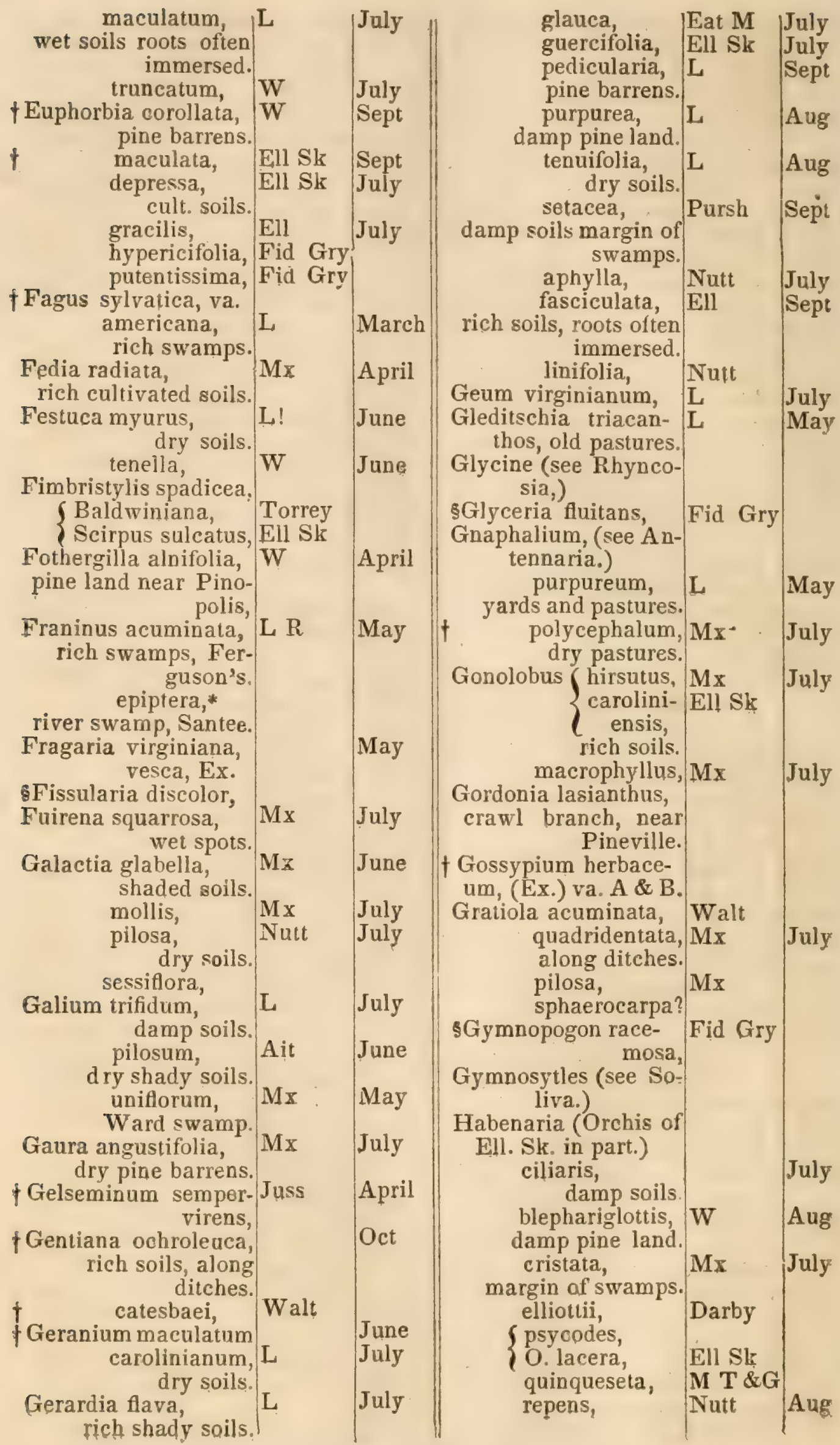


Halesia tetraptera, very ornamental Upper St. Joha's, Santee river, garden at Woodlawn plantation.

† Hamamelis virginica, L rich land margin of swamps.

Hedyotis coerulea, T \& G

Houstonia Ell. Sk.

\{ va. minor,

Houstonia patens, Ell Sk yands, wet pastures. purpurea rotundifolia,

Hedysarum (see Des. Mx modium.)

Helianthemum caroli-WSESk Aug nianum. canadense,

Helianthus atroreubens,

rich cultivated soils.

trachelifolius,

aristatus,

sparsitolius,

strumosus va. angustifalius,

angustifolius!

L

S strumosus $\nabla$. mollis, $T \& G$

$\{$ mollis,

gigantens ?

scaberrimus,

hispidulus ? -

anus, Ex.

tuberosus, Ex. Nat.

Heliopsis laevis, Pers

Helenium quadridentatum,

Heliotropium indicum M

seen by Mx. at the

Eutaw spring.

+ Helonias erythrosper- $\mathbf{M} \mathbf{s}$ ma.

rich oak land, margin

of swamps, Brunswick PI.

$\dagger$

dioica, ancustifolia Purs

Hemerocaulis fulva,

W \&ESk

\section{Sept}

Aug

Aug

Iarch

A pril

dry parrens.

Hopea tinctoria,

rich vak and hickory

land, Ward swamp.

Hordeums pratense, vulgare, Ex.

Houstonia, (see Hedzotis,

+ Humulus lupalus, L

Hydrangea nivea, Mx

St. John's, Elliott.

Hydrocotyle umbella- L

ta, wet soils general-

ly immersed. interrupta, W

border of ditches and inundated land. repanda,

pine land ponds.

Hydropeltis, Brassenia of Ell. Sk.

purpurea, immers- Mx ed in stagnant water.

Hydrolea quadrival- Wr

vis, border of rivulets and ditches. corymbosa, Macb

very rare, St. Stephen's, Horsehead immersed.

Hypericum prolificum $W$

Jaly maculatum, T\&G W July

$\{$ mutilum, L\&T\&G \{ parviflorum, MxElSk

wet pine land swamps. angulosum, L

A pril

+ Hepatica triloba, Ex.

Entaw battle ground.

Herpestes amplexi- Pursh

caulis, roots submersed ponds. micrantha, Ell Sk

Heuchera americana Lower St. Jobn's.
Aug

Aug

Aug

July

April

May

June

July

July

June

Aug

June wet pine land barrens.

See T. cystifolium, Lam

\& G. opacum,

p. 673 rosmarinefolium.

f sarothra,

$\{$ Sarothra gentia.

noides, dry pastures. 


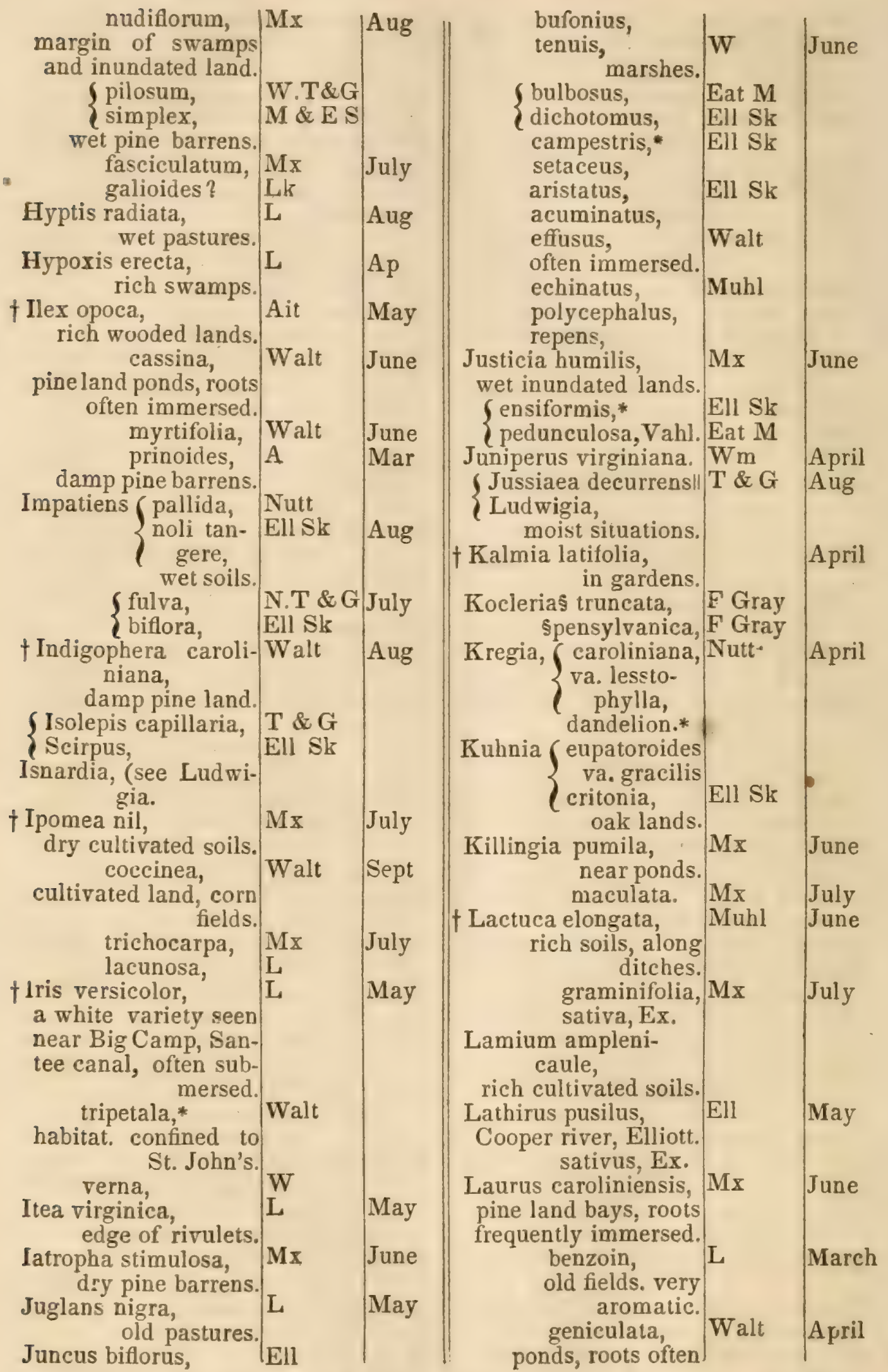

I. Dr. Cartwright, of Natchez, remarks that the Jussiaea grandiflora neurralizes the influence of malaria in the lower portion of Louisiana-a section which is exempt from its effects, and where there is, apparently, every element for its abundant production. He is quoted in the notes appended by the American editor to Watson's Practice of Physic. The Faculty may notice that this plant is abundant around Charleston, for the space of ten miles, in situations where it is wel! known that fevers of malarious origin are continually prevailing. 


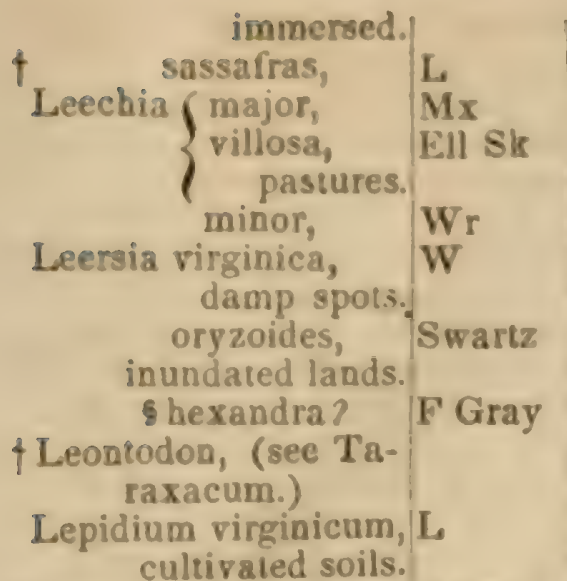

5 Leptochloa filiformis, F Gray Leptopoda ( fimbriata Eat Man $\left\{\begin{array}{c}\text { pubes- Ell Sk } \\ \text { cens, }\end{array}\right.$ $\$$ brachypoda, F Gray S belenium, Nutt decurrens, McB dry rich soils.

Lepuropetalon spathulatum.
Lespedeza (stuvei, $\quad$ T \& G $\left\{\begin{array}{c}\text { va. } 1 \\ \text { violacea, Ell Sk }\end{array}\right.$ procumbens, $\mathrm{Mx}$ road sides.

f violacea va. sessi- $T$ \& \& $G$ liflora,

sessiluflura, Ell Sk hirta, dry soils, Ell T \& G f capitata va. 3, T \& G angustifolia, Ell Sk

Leatris, (see Carpephorus,

Ligusticum, (see Thaspium,)

Lilium catesiaei, flat Walt pine lands carolinianum, $\mathbf{M x}$ flat pine lands. superbam, Walt (cult.)

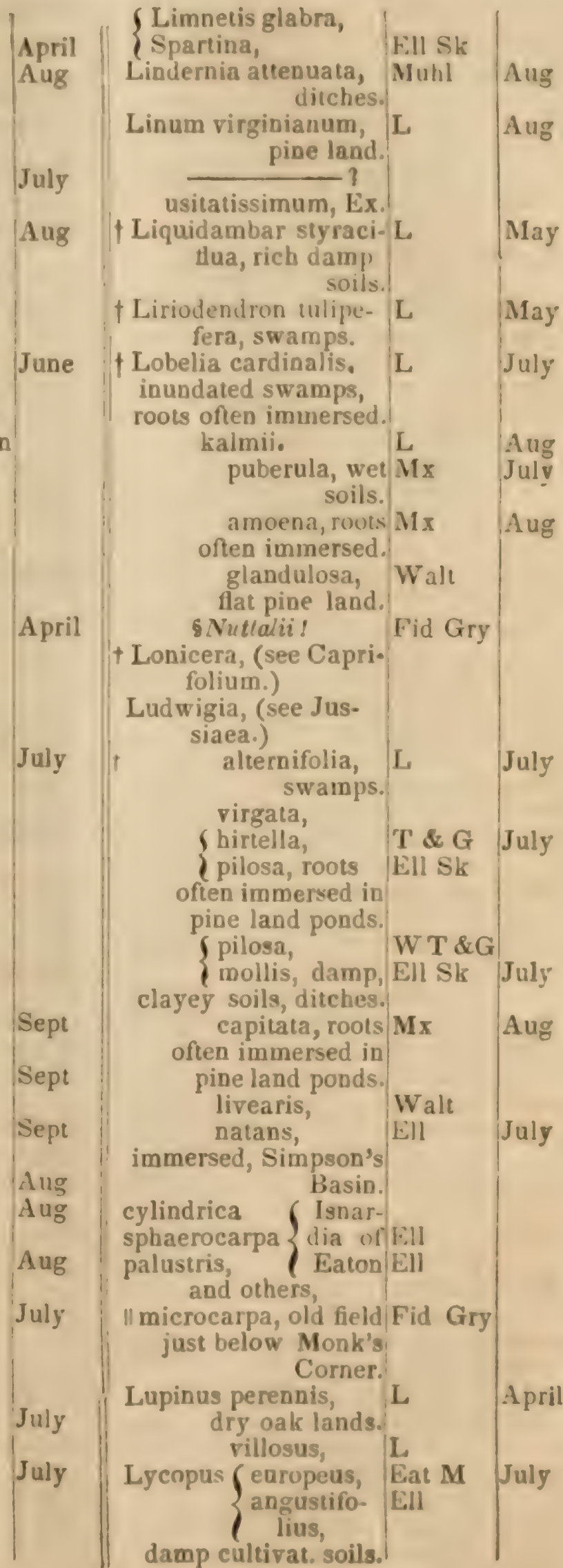




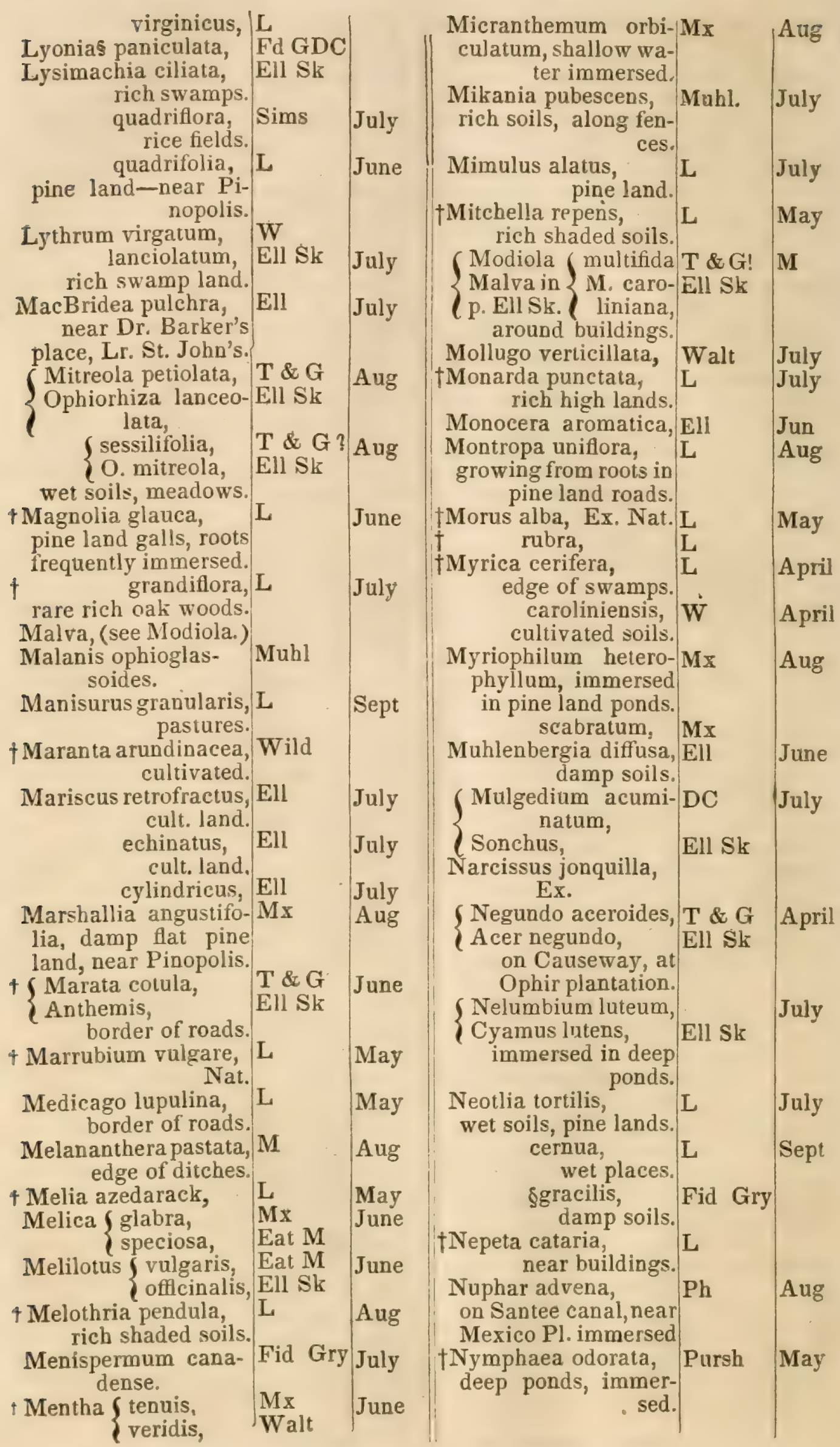




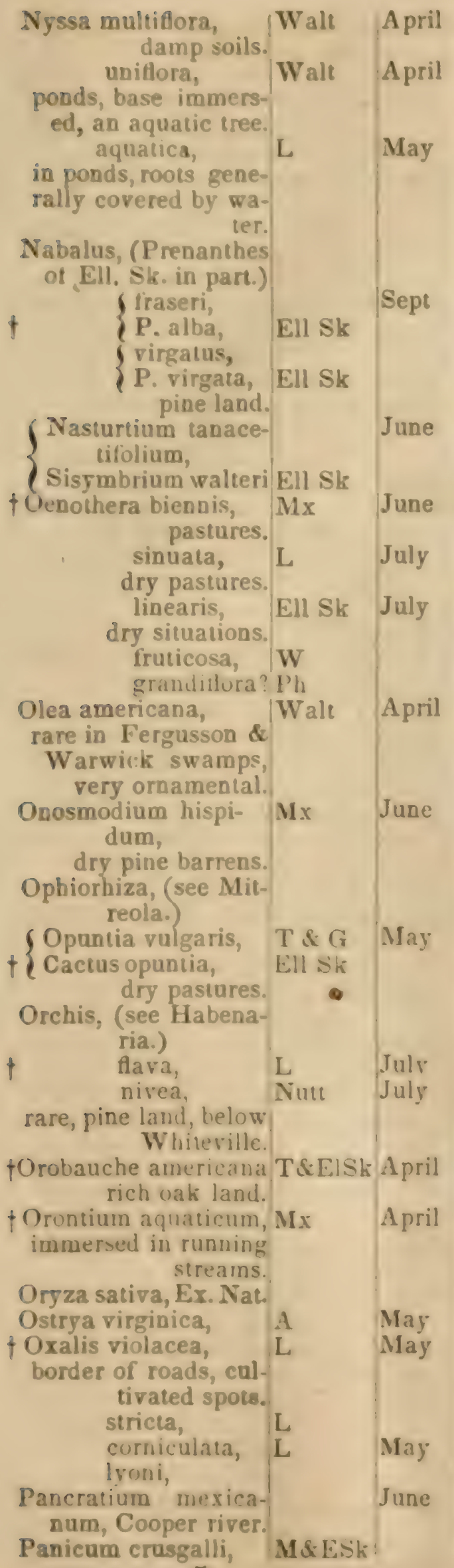

\author{
walteri, Ell Sk \\ histellum, M\& ESk \\ gibbum, Ell sk \\ wet soils, \\ geniculatum, MbEISk \\ rice fields. \\ anceps, ditch's MxEISk
}

hians, Eill Sk

latifolium, Ell Sk

pauciflorum, Ell Sk

scabriusculum, Ell Sk

debile, Eil Sk

- capillare,

macrocarpon, Lc

virgalum,

agrostoides,

nervosum,

viscidum, EISkM

Ell $S$

villosum, Ell Sk

barbulatum, MxElSk

nitidum, rice fields.

angustifolium, Ell Sk

See T \& Gray's Bot.

Vol. 1, p. 670.

Paspalum ciliatifo- $\mathbf{M x}$

lium, cult. grounds.

floridanum, Mx

praecox, Walt ditches.

purpurascens, Ell Sk

damp situations.

distichum, L

wet soils, rice fields.

Passiflora incarnata, W May

dry sandy fields.

lutea,

cultivated soils, not

common, corn fields.

Pedicalaria canaden- L June

sis, swamp, near So-

merset $\mathrm{Pl}$.

$\left\{\begin{array}{c|l}\begin{array}{c}\text { Pennisetum glau- } \\ \text { cum, }\end{array} & \text { Eat Man } \\ \begin{array}{c}\text { Panicum, } \\ \text { va. 1. }\end{array} & \text { Ell Sk }\end{array}\right.$

Penthorum sedoides, L Aug

swamps and inunda-

ted land, often im-

mersed.

Penstemon laeviga- I

tum, damp soils pine

land bays, rare. pubescens, $\mathbf{L}$

rare, near Pinopolis, an upper country spe-

Petalostemon corym-Mx bosum, pine barrens. 
Phaseolus perennis?

Lower St. John's.

Shelvolus, T \& G

$\{$ strophostyles pe-Ell Sk

duncularis,

Phalaris americana, Ell river swamp.

Philadelphus grandiflora,

planted as an ornamental shrub.

Phleum pratense, cult. L

Phlox maculata, L setacta, Mx

Upper St. John's.

nitida, rich soils. paniculata?

one of Elliott's upper country species. pilosa, cultivated spots.

Phryma leptostachya, Mx rich shaded soils, Somerset swamp.

Phyllan- (obovatus, Eat M thus, $\{$ carolinien- Ell Șk

Physalis, (viscosa, L obscura, $\mathbf{M x}$ ( pubescens, W

cultivated ground.

† Phytolacca decandra, L around buildings.

Pinguicula elatior, $\mathbf{M x}$

damp flat pine lands,

Horsehead, St. Stephen's. Jutea,
flat pine lands. Walt

May dry sandy soils. taeda, L damp, moderately fertile soils. inops, variabilis, serotina, $\mathbf{M x}$ wet soils

Pisum sativum, Ex. † Plantago major, damp cultivated soils, grows in Charleston. angulata?

† Pinus palustris,

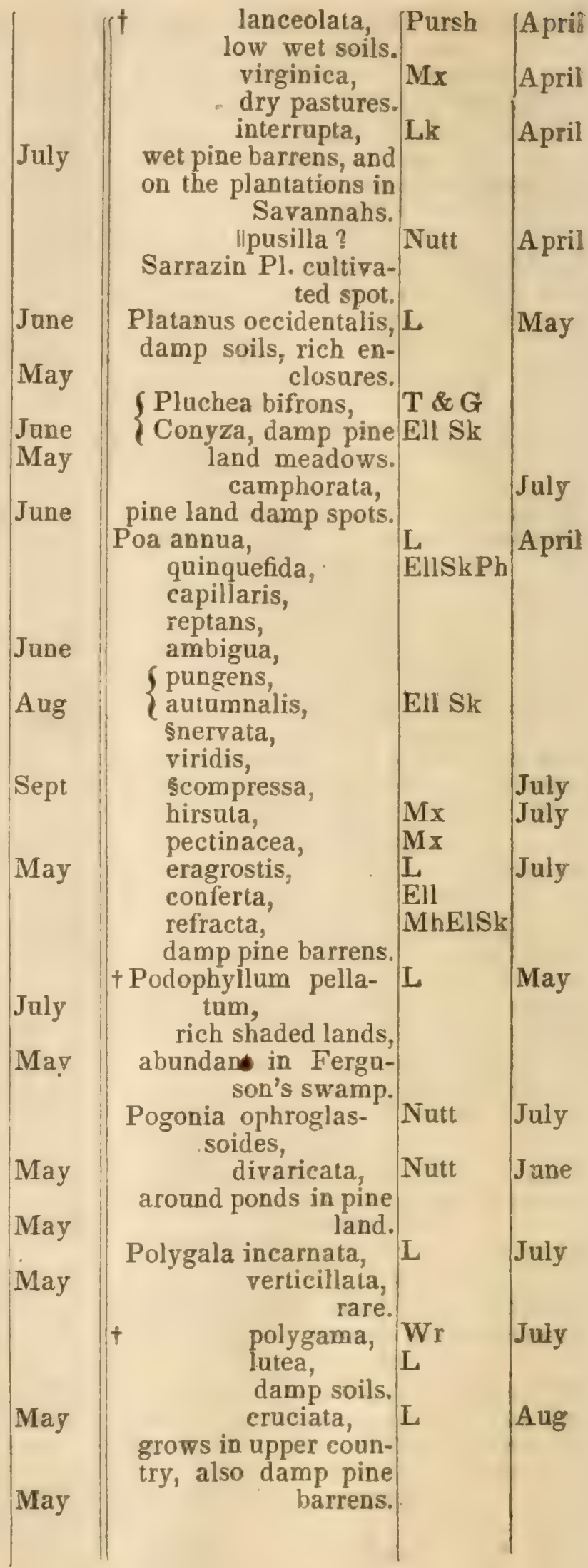

|l Elliott has evidently not alluded to this plant. I find two species, one growing in yards and cultivated soils, allied to the P. Virginica, the other seen in morass at Mulberry Castle, C. river, and resembling $P$. Major. The latter is p obably the same with one from this locality, which 1 understand Prof. Gray has determined to be a P. Kamscatchkia! not heretofore seen in the United States. 


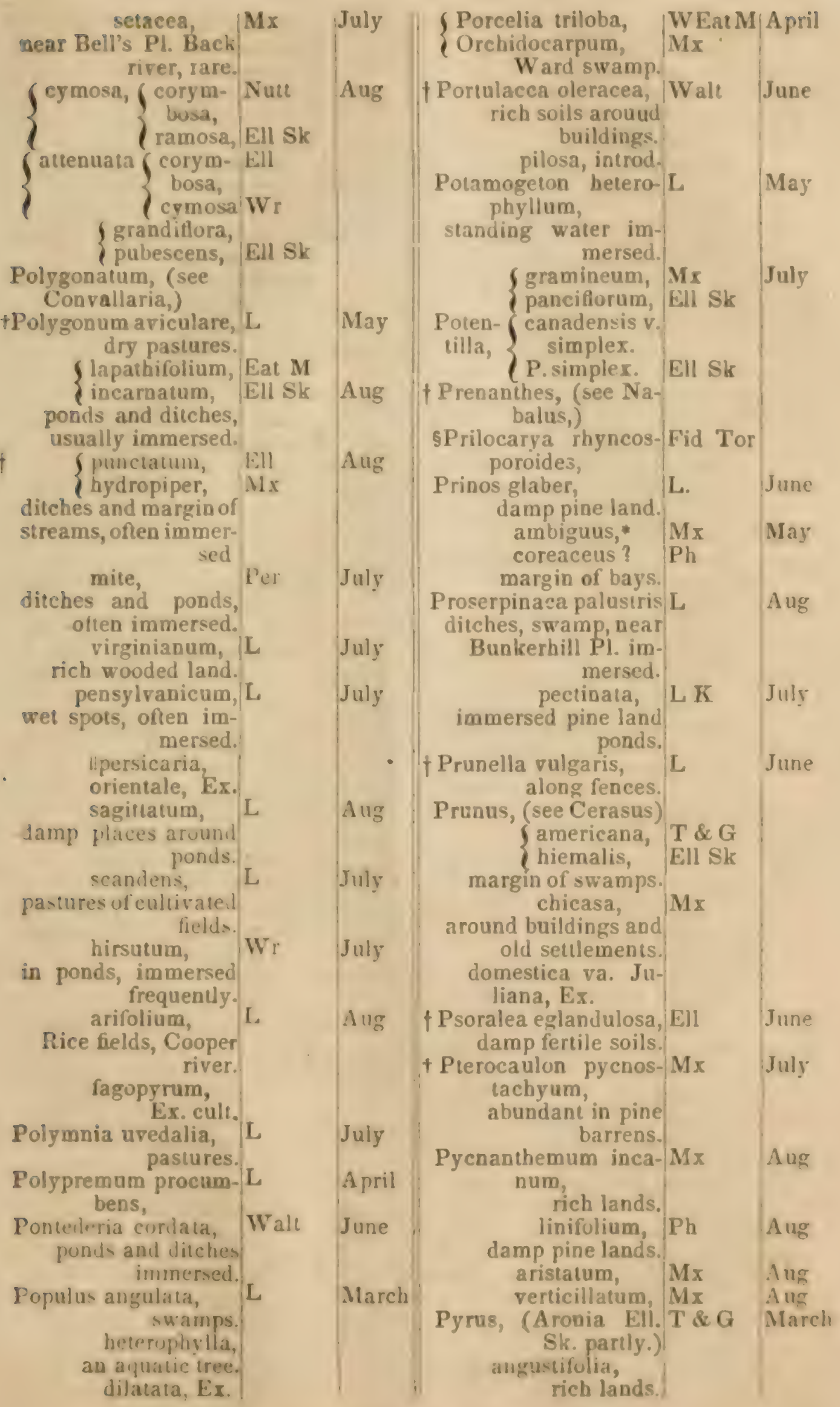

I In El]. 8k. a synonyme of Walt. under P. punctatum. 


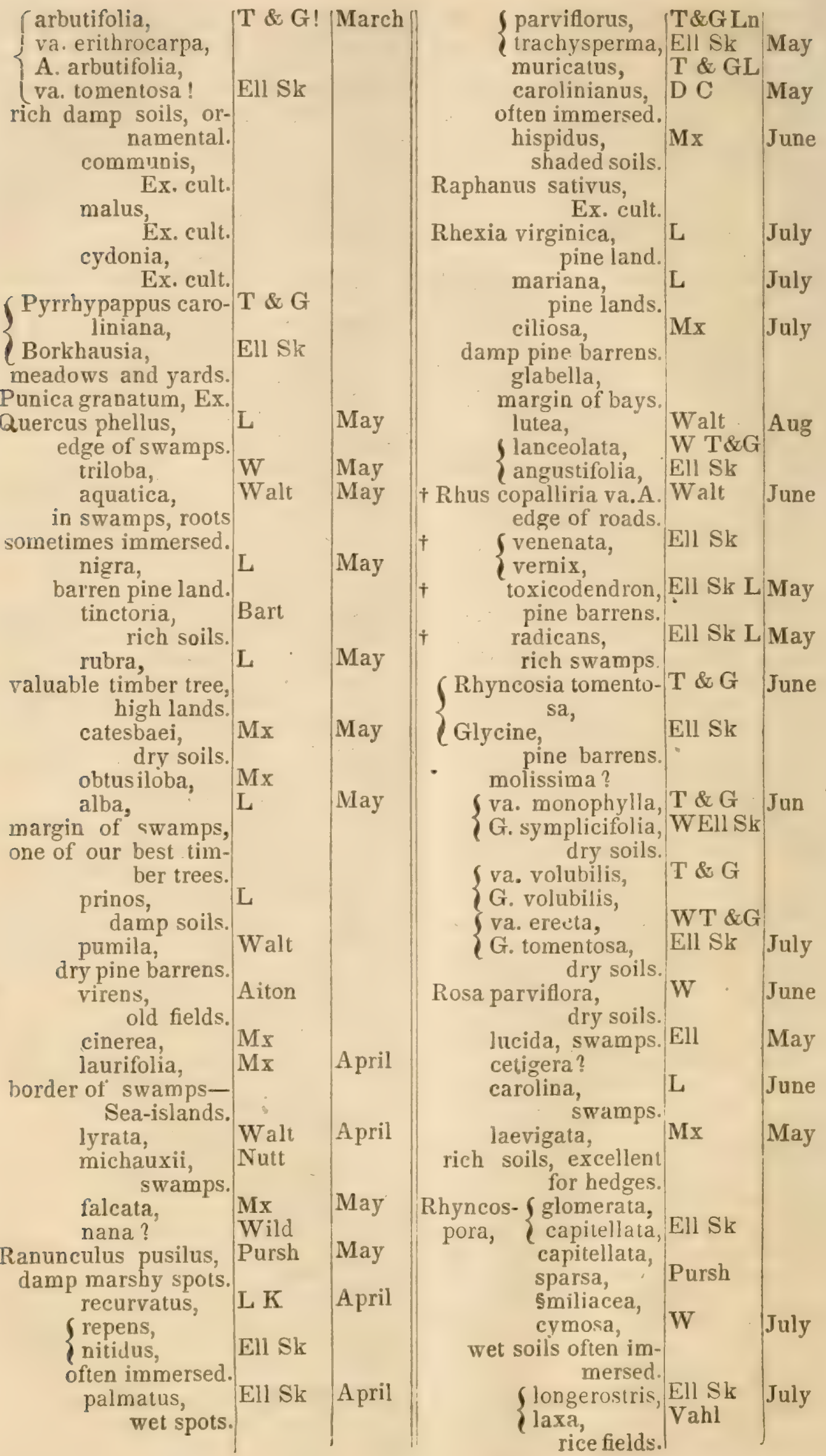




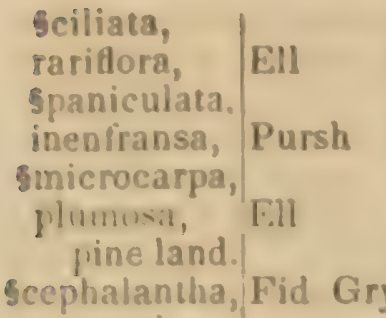

Ricinus communis, rich spots near buildings.

Rotbollia scorrugata,

Robinia pseuduacacia, Lower St. John's.

† Ruellia strepens, wet swamps often iumersed.

Rudbeckia mollis,

laciniara va.2,
liviliti,
fulgida,

\section{+ Rubus villosus}

$+$

Sabal pumila \begin{tabular}{l|l}
$\begin{array}{l}\text { trivialis, } \\
\text { occidentalis, } \\
\text { cuneifulius, }\end{array}$ & A \\
Pursh
\end{tabular} sandy soils.

ideuv, Ex.

+ Rumex crispus, clase soils.

f britanicus, L damp soils. acetosellus, $\mathrm{L}$ sandy soils. pustalulu: Bali fields. persicaroides, L. pulcher, L Ex. Nat.

+ Sabbatia angularis, Pursh

rich wet soils, near

White Hall Pl. calycosa,

wet soils, near swamps. chloroides, $\mathbf{M x}$

near pine land ponds. roots onen immersed. corymbosa, Bald

wel pine barrens. gracilis,

+ Sagittaria sagittifolia, $\mathbf{M}$ 工

pear Cooper river. generally immersed. Sradicans, Nutt
graminea,

pine barren ponds, sometimes immersed. natans, $\mathrm{Mx}$

immersed, pond in Stoney Landing Pl.

\begin{tabular}{|l|} 
May \\
June \\
July
\end{tabular}

May

May

June

July

July

rare, Mulberry Castle, Cooper river. obovata. rich shaded soils. officinalis, t

Sambucus canadensis L damp suils.

+ Samolus valerandi, L

old rice fields, often immersed.

+ Sanguinaria canaden-L sis,

rich shajed soils, not uncommon.

Sanicula marylandica $\mathbf{L}$ rich shaded soils.

\section{Sarothra,}

(see Hypericum.)

- Sarracenia flava, damp soils, near Pivariolaris, $\mathbf{M x}$

wet pine barrens.

+ Saururus cernuus, 'L . inundated swamps.

Secale cereale,

Schoenus effusus, Ex. cult.

Schrankia Sangustata, Fid Gry pine barrens, sensi. tive $\mathrm{pl}$.

+ Scirpus palustris, rice fields often immersed. capitatus,
L ten immersed.

bogs often immersed. capillaceus, Ell Sk damp soils. lacustris, marshes often im. mersed. maritimus, Seriophorum, Eriophorum Ell Sk cyperinum, triqueter, minimus, Ell Sk lineatus,
June

May

March

June<smiles>C1CCCC1</smiles>

Aug

May Sept 


\begin{tabular}{|c|c|c|c|c|c|}
\hline $\begin{array}{r}\text { tuberculatus, } \\
\text { wet soils frequently } \\
\text { immersed. } \\
\text { quadrangulatus, } \\
\text { rice fields, marshes. } \\
\text { equisetoides, } \\
\text { seen by H. W. R. in } \\
\text { the spot mentioned } \\
\text { by Elliott. } \\
\text { divaricatus, } \\
\text { pine land. } \\
\text { pastures. } \\
\text { Schleria reticulata, } \\
\text { oligantha, } \\
\text { C. River. } \\
\text { hirtella, } \\
\text { damp soils. } \\
\text { verticillata, } \\
\text { Scrophularia mary- } \\
\text { landica, } \\
\text { rich shaded soils. } \\
\text { t Scutellarialateriflora, } \\
\text { integrifolia, } \\
\text { wet spots, edge of } \\
\text { roads. } \\
\text { pilosa, } \\
\text { rich soils. }\end{array}$ & $\begin{array}{l}\text { Ell } \\
\text { Mx } \\
\text { Mx } \\
\text { Mx } \\
\text { L } \\
\text { L } \\
\text { L } \\
\text { Mx } \\
\text { T \& G } \\
\text { Ell Sk } \\
\text { L } \\
\text { Pers } \\
\text { Pursh } \\
\text { T \& G } \\
\text { Ell Sk } \\
\text { Mx \& G }\end{array}$ & $\begin{array}{l}\text { Aug } \\
\text { Aug } \\
\text { Aug } \\
\text { Aug } \\
\text { May } \\
\text { May }\end{array}$ & 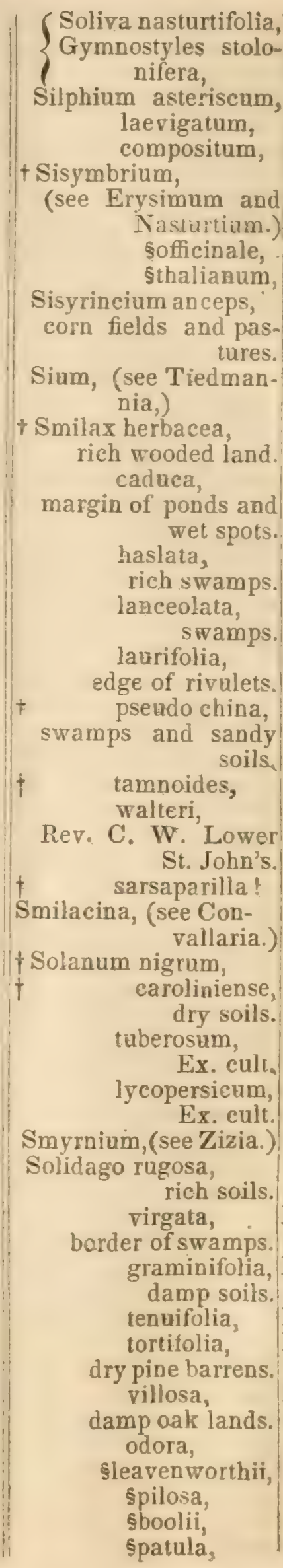 & \begin{tabular}{|l} 
\\
L \\
Wild \\
Mx \\
Ell \\
Pursh \\
Ell \\
Ph
\end{tabular} & $\begin{array}{l}\text { Aprit } \\
\text { June } \\
\text { July } \\
\text { June } \\
\text { June } \\
\text { April }\end{array}$ \\
\hline
\end{tabular}




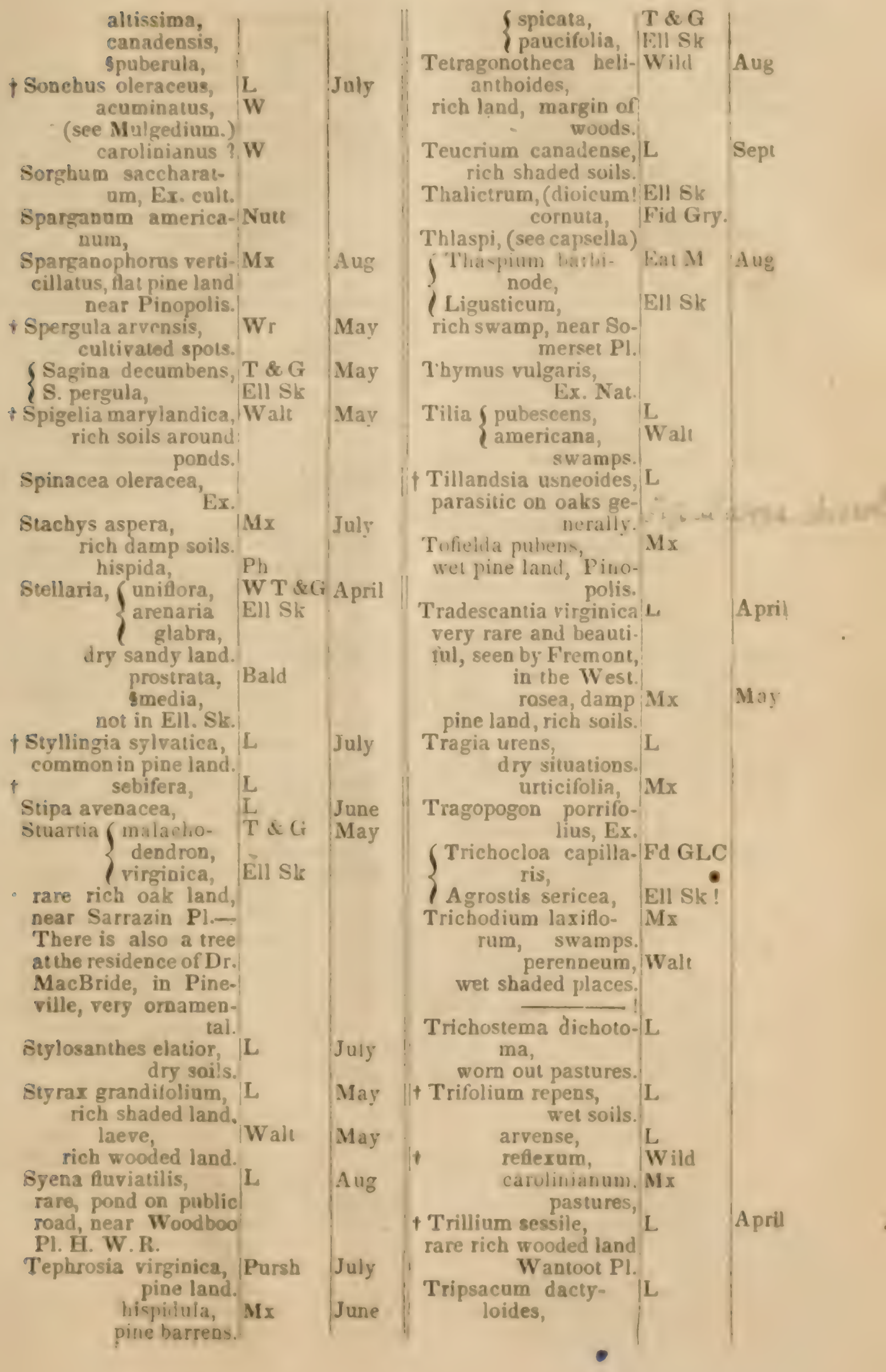


+ Typha latifolia stagnant water often immersed.

Tripterella capitata, Walt rare old field, below Pinopolis. t coerulea, rare, near Pinopolis.

+ (Taraxacum dens T \& G
$\{$ leonis,
Leontodon taraxa- Ell Sk cum,

rare, wet spot, Ophir $\mathrm{Pl}$. common in the streets of Charleston. Tiedmannia, (Sium of Ell. Sk. partly. teretifolia, margin of pine land bays, Pinopolis.

† Ulmus americana, $\mathbf{M x}$ swamps. alata, swamps $\mathrm{Mx}$

Uniola latifolia. Mx collected also by $\mathrm{McB}$. in the Mts. gracilis, rich shady soils. nitida,

Urtica capitata, damp shaded soils. pumila,
damp shaded land. Mx Bald I divaricata?

Utricularia inflata, Susey's Reservoir, gibba, immersed. L

pond near Santee canal, immersed. $\{$ purpurea, saccata,

near Walter's old residence. bipartita, longirostris, on logs in ponds near Santee Canal. personata, pond just above $\mathrm{Pi}$ Lc

napolis, sometimes immersed. setacea, Walt

Aug

W EllSt July

March

March

April

Aug

June L July LC Ell Sk

July

old field, near PinoMx

Uvaria triloba, fibrosa,* Walt immersed.

Tvularia perfoliata, L rare, rich land, Brunswick PI.

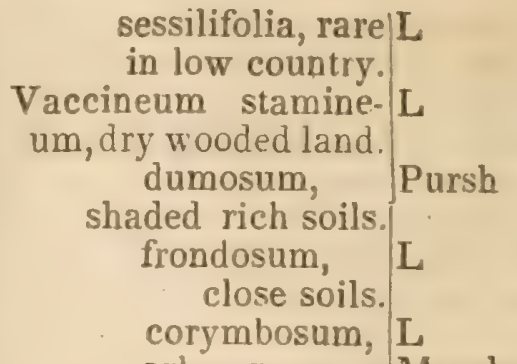

sessilifolia, rare $\mathbf{L}$ in low country.

Vaccineum stamine- L um, dry wooded land. dumosum, Pursh

shaded rich soils. frondosum, L close soils. corymbosum, L m, L April wet soils. galezans, $\quad \mathbf{M x}$ nitidum? $\mathrm{Ph}$ $\begin{array}{cll}\text { nitidum? } & \text { Ph } & \text { May } \\ + \text { Verbascum thapsus, } & \text { Walt } & \text { June }\end{array}$ pastures. + blattaria va.a. \& b. Smith July along Santee Canal, Big Camp.

† Verbena urticifolia, L wet soils. caroliniana, L

Verbesina siegesbec- $\mathbf{M x}$ kia, along fences. virginica, L

April May May May June July

Vernonia novaebora-Wild censis,

wet spots along rivulets oligophylla, Mx margin of pine land: bays. angustifolia, $\mathbf{M x}$ pine land. scaberrima, Nutt pine barrens.

Veronica arvensis, Walt damp yards, in Lower St. John's. peregrina, fields. Mx Viburnum prunifo- Walt lium, rich soils. nudum, along rivulets.

dentatum, va. b. L rich shaded soils. obovatum, Walt Aug July July

Aug Aug: May May

May

May margin of streams. cassinoides, W along streams, bays, opulus, Ex.

+ Vicia sativa! $\& c$. acutifolia, faba, Ex. $\left\{\begin{array}{c}\text { trachys- } \\ \text { perma }\end{array}\right.$ L April immersed Santee ca-
June

April July

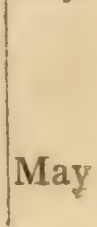
Viola palmata va. nal. 


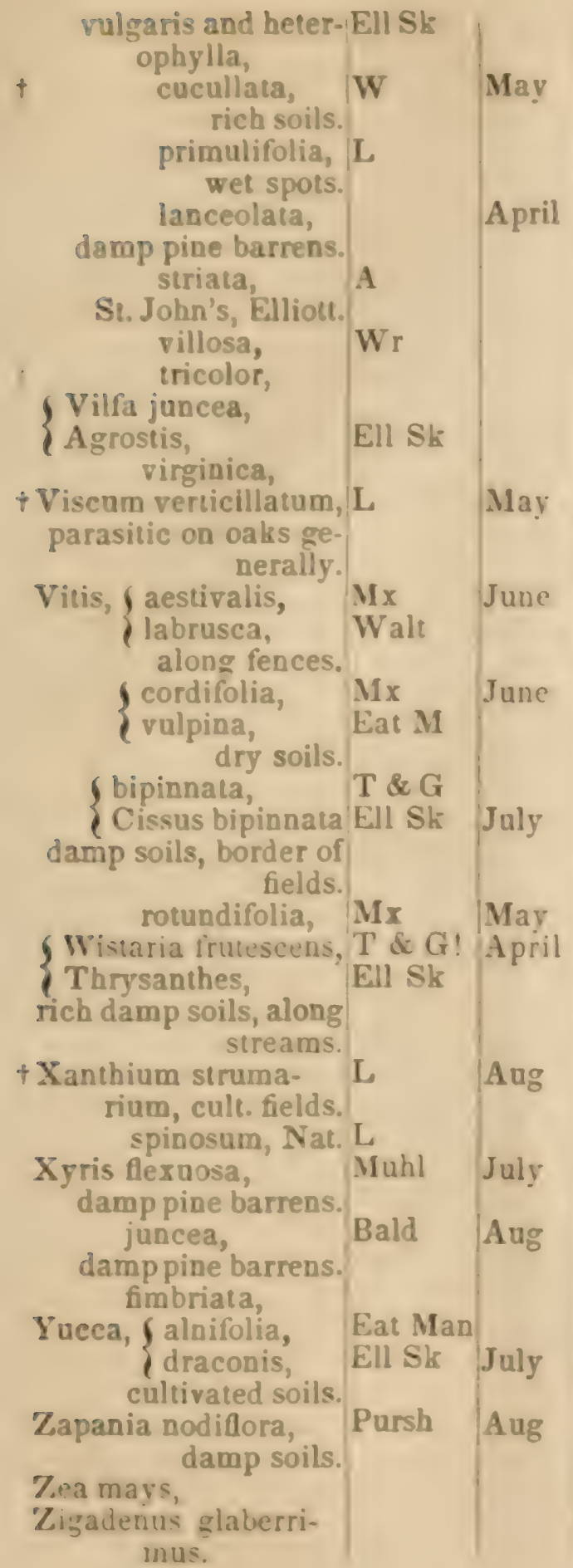

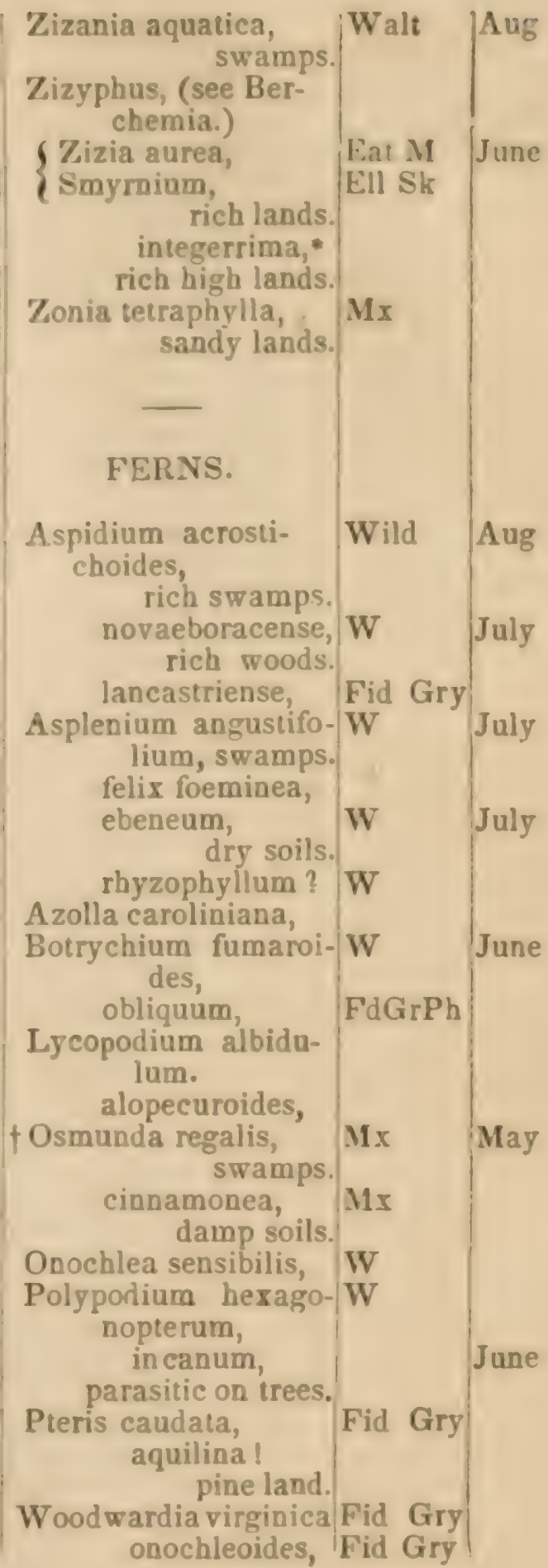



. 




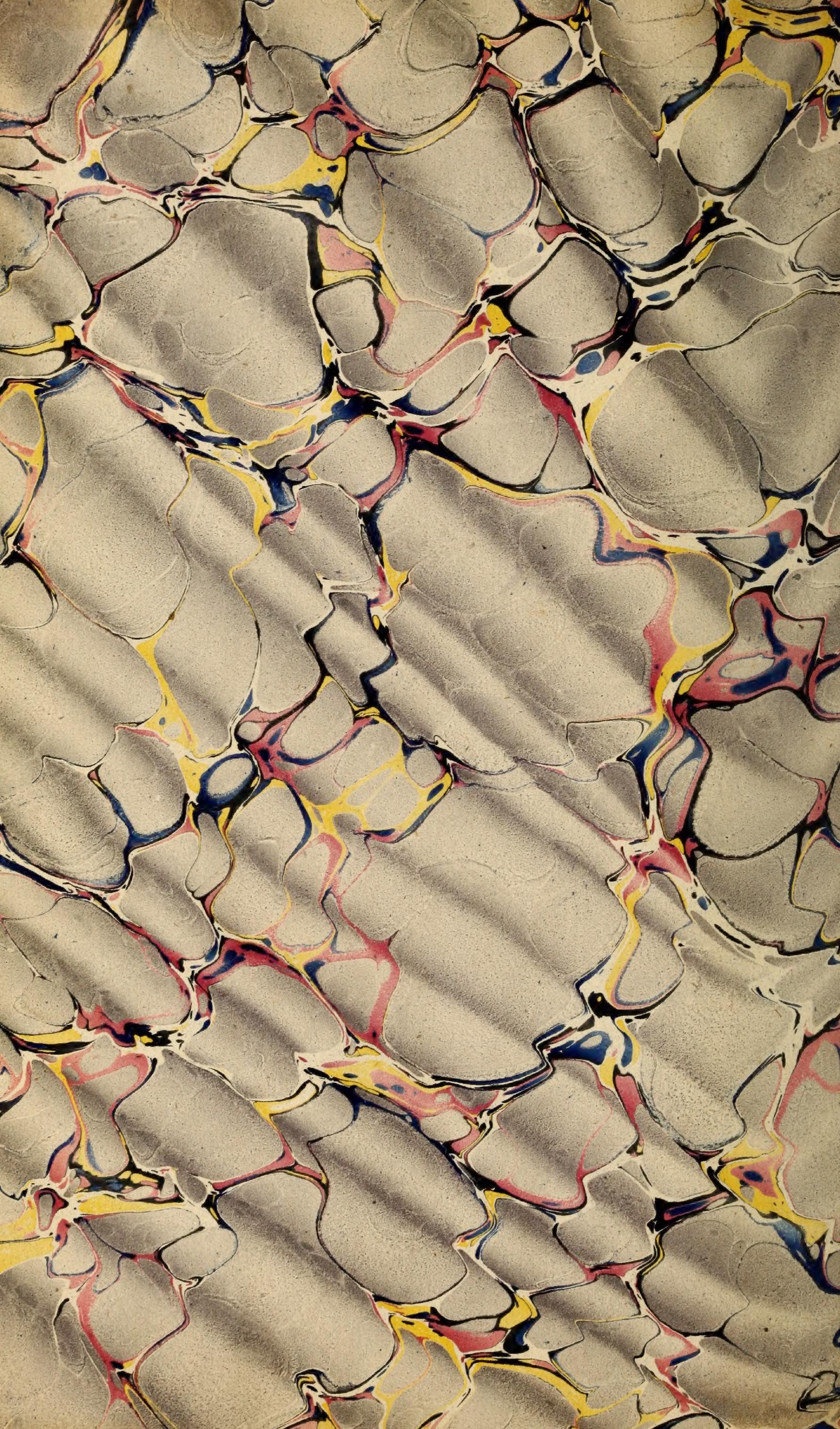


